Article

\title{
Natural Recovery and Liming Effects in Acidified Forest Soils in SW-Germany
}

\author{
Lelde Jansone *, Klaus von Wilpert and Peter Hartmann \\ Department of Soil and Environment, Forest Research Institute of Baden-Württemberg, \\ D-79100 Freiburg, Germany; klaus.von-wilpert@online.de (K.v.W.); Peter.Hartmann@Forst.bwl.de (P.H.) \\ * Correspondence: Lelde.Jansone@Forst.bwl.de; Tel.: +49-761-4018-217
}

Received: 15 May 2020; Accepted: 23 June 2020; Published: 30 June 2020

\begin{abstract}
In the state of Baden-Wuerttemberg, Southwest-Germany, a large-scale forest liming trial was government-funded in 1983 and a lime treatment was carried out in autumn 1983 until early winter 1984. Repeated liming was applied in 2003. The limed sites and adjacent control plots were surveyed repeatedly: in 2003 before the second lime application and again in 2010 and 2015. Research of this scope presents a rare opportunity to evaluate firstly the long-term development of acidified soils with their potential for natural recovery on established control plots, and secondly the long-term effects of repeated lime application - at a collective of study sites of various growth regions and soil properties. A natural recovery in soil $\mathrm{pH}$ was observed since 2003, on average limited to an increase of $0.2-0.4 \mathrm{pH}$ units in the forest floor and $0.1-0.3 \mathrm{pH}$ units in the mineral soil until 2015. The majority of the organic layers still show very strong or extreme acidity with a $\mathrm{pH}$ value 3.9 on average and in the mineral soil with $\mathrm{pH}$ values between 3.8 and 4.6 on average. The exchangeable cations calcium and magnesium slightly increased also, although the base saturation remained $<20 \%$ by 2015 . The exchangeable acid cation concentrations indicated no significant changes and thus no recovery. The lime treatment greatly accelerated the rise in $\mathrm{pH}$ by $1.2-1.3$ units and base saturation by $40-70 \%$ in the organic layer, as well as $0.3-1.2 \mathrm{pH}$ units and base saturation by $7-50 \%$ in mineral soil. These effects were decreasing (yet still significant) with depth in the measured soil profile as well as with time since last treatment. Changes in soil cation exchange capacity after liming were significant in $0-5 \mathrm{~cm}$ mineral soil, below that they were negligible as the significant increase in base cations were accompanied by decreasing acid cations aluminum and iron (III) especially in the upper soil profile. Additionally, a decrease of forest floor and an enrichment of organic carbon and nitrogen in the mineral topsoil tended to follow liming at some sites. Overall the liming effects had a high variability among the study sites, and were more pronounced in the more acidic and coarser textured sites. Liming of acidified forest soils significantly adds to natural recovery and therefore helps to establish greater buffering capacities and stabilize forest nutrition for the future.
\end{abstract}

Keywords: acid deposition recovery; forest soil; liming

\section{Introduction}

Forest soils in Central Europe underwent acidification in the 20th century, which was primarily due to anthropogenic emissions of $\mathrm{SO}_{2}$ and $\mathrm{NO}_{X}$ that became acidic compounds in precipitation as well as dry deposition, and depletion of organic matter from topsoil [1,2]. In the 1970s-1980s a phenomenon of "forest dieback" - a new challenge due to deteriorating forest crown condition-was identified. Over time, several ecological effects of the acidifying agents sulfur, nitrogen as well as ozone have been identified: harmfully affected assimilation organs of trees, damaged tree roots with declining fine root biomass, changes in ectomycorrhizal associations and in fine root distributions, magnesium deficiencies in acidified soil and nutrient imbalances due to nitrogen eutrophication [3-5] 
(p. 30). Earthworms-important ecosystem engineers-are also known to avoid acidic $(\mathrm{pH}<3.6)$ and high aluminum content soils [6]. The overall functioning of the forest ecosystems has been shown to be impeded in acidified conditions [7].

The acid-base status of forest soils is typically evaluated by the $\mathrm{pH}$, base saturation and reciprocal to it the exchangeable acid cations $\mathrm{Al}, \mathrm{Fe}, \mathrm{Mn}$ and $\mathrm{H}$. Acidified soils experience a reduction in their natural acid neutralization capacity (ANC) as the $\mathrm{pH}$ decreases and with it the soils' buffering range shifts [8]. For forest soils in Southwest Germany a distinct change of $\mathrm{pH}$ values between the years 1927 and 1997 was reported with a $\mathrm{pH}$ reduction of up to $2 \mathrm{pH}$ units in the top-soils [9]. Many soils have left the silicate buffer range and reached $\mathrm{pH}$ values buffered by aluminum-oxides and aluminum-hydroxides, with potentially adverse effects on plant roots and soil organisms, as well as hampered phosphorus availability [10-12] (pp. 94-96). Since the long-term buffering of acids in soils depends on the weathering rate of primary minerals, in carbonate-free soils the base cations $\mathrm{Ca}, \mathrm{Mg}, \mathrm{K}$ and $\mathrm{Na}$-also important tree nutrients—are being released from silicate and clay minerals and leached, leading to further nutrient imbalances in already base poor soils $[8,13]$.

Due to legislative measures such as the Convention on Long-Range Transboundary Air Pollution of the United Nations Economic Commission for Europe [14] the emissions of $\mathrm{SO}_{2}$ have been successfully reduced, however a legacy of $\mathrm{S}$ compounds is still stored in soil and delays the recovery from acidification. On the other hand, in many regions, the deposition on $\mathrm{N}$ compounds $\mathrm{NO}_{3-}$ and $\mathrm{NH}_{4+}$ remains high, and continues to impact the forest ecosystems. Meanwhile, also $\mathrm{Ca}$ and $\mathrm{Mg}$ deposition rates have been decreasing $[2,13,15]$. Forest soil inventories in Germany prove that soil acidification still is an ongoing process with decreasing base saturations in the mineral subsoil (below $5 \mathrm{~cm}$ ) while $\mathrm{pH}$ values showed a slight recovery in the topsoils and no changes in the subsoils at unlimed sites [12] (pp. 93-116).

Since natural soil development and, in this case, recovery is expected to be a slow process, forest soil liming may be an effective counter-measure to help alleviate the consequences of soil acidification [16]. Liming is the application of buffering compounds-most commonly calcite (calcium carbonate, limestone and $\left.\mathrm{CaCO}_{3}\right)$ and dolomite $\left(\mathrm{CaMg}\left(\mathrm{CO}_{3}\right)_{2}\right)$-in order to restore acid deposition impaired soils [17]. In Finland and Sweden liming was studied extensively already in 1950s for its potential to accelerate N-mineralization in the organic soil [18]. In Germany lime application has been a wide-spread forestry practice since the mid-1980s to compensate acid inputs and remediate acidified soils, in order to improve the forest stand vitality [5] (pp. 38-39). A great number of studies have attempted to characterize the effects of liming. In a meta-study on liming and wood-ash treatment effects on forest ecosystems Reid and Watmough [17] showed that the most significant impacts of liming were on soil $\mathrm{pH}$ and foliar $\mathrm{Ca}$ concentrations, best predicted by the soil type and time since treatment, and by the treatment dose and type respectively. Other important indicators of liming success were base-saturation, as well as various tree growth measures. Meanwhile a number of studies reported no significant liming effect at all. Šrámek et al. [19] showed significant increase of soil pH as well as exchangeable $\mathrm{Ca}$ and $\mathrm{Mg}$ up to five years after liming in upper soil horizons, with the effect decreasing ten years after treatment. Ouimet and Moore [20] found similar effects seven years after liming, along with a slight decrease in exchangeable $\mathrm{K}$ and strongly decreased exchangeable acidity-with an increased lime dose. In a study that found increased soil profile $\mathrm{pH}$ as well as changes in sorption complex of the forest floor 16 years since last liming Drápelová et al. [10] pointed out the role of site soil properties, climate and tree species composition in the outcome of liming in a study, which found increased soil profile $\mathrm{pH}$ as well as changes in sorption complex of the forest floor 16 years since treatment. Saarsalmi et al. [18] showed decreased acidity and improved base saturation in the organic layer and topsoil of Norway spruce and Scots pine stands even 20 years after liming. Similarly, Court et al. [13] observed a trend of increased $\mathrm{pH}$, base saturation, $\mathrm{Ca}, \mathrm{Mg}$ as well as decreasing exchangeable $\mathrm{Al}$ more than 20 years after lime application in beech stands. Increased tree growth was also noted in this study, likely due to the improved soil chemical and biological properties even 40 years after. In Germany the results of the second national forest soil inventory (NFSI) of 2006-2008 also 
showed overall positive liming effects on forest soil acid-base as well as nutrient status since the first survey in 1987-1992, noting also a decrease in N stocks in the organic layer with an increase in the 0-30 cm mineral soil [21] (p. 157). This observation was attributed to increased soil $\mathrm{pH}$ stimulating the microbial activity and decomposition of organic matter, with no notable change in the $\mathrm{C} / \mathrm{N}$ ratio.

Thus the relevance of forest liming lies in its potential to both restore and preserve the sustainability of soils' functionality: acid buffer capacity, nutrient supply for forest growth, leading to improved structural integrity of the ecosystem. Meanwhile, as the acid deposition distinctly decreased since the 1980s it might currently be sufficiently counteracted and buffered by natural soil weathering, whereby a trend reversal from deposition driven acidification to a natural recovery might have taken place. With this in mind, the soil chemical parameters and their temporal development were studied at ten long-term lime treated research sites in the Southwest-German state of Baden-Wuerttemberg in order to answer the following questions:

1. Has natural recovery of acidified forest soils taken place since 1980s, and to what extent?

2. Has liming been an effective counter-measure to forest soil acidification?

3. What site parameters dictate the extent of change in soil acidity status in case of (1) and (2)?

\section{Materials and Methods}

\subsection{Site Description}

The ten study sites are located in the SW-German state of Baden-Wuerttemberg, first described by Littek [22] (pp. 1-8, 14) and Wilpert et al. [23] (pp. 1, 7-22). They were initially selected in 1983 according to the following criteria: porous, non-waterlogged, severely acidified soils on sandstone substrates in the regions of Black Forest, Forest of Odes and Neckarland, as well as on Pleistocene deposits in Alpine foothills, with larger, homogeneous stands (10-50 ha) of Norway spruce (Picea abies) in pure stands or mixed with Silver fir (Abies alba), Scots pine (Pinus sylvestris), Douglas fir (Pseudotsuga menziesii) and European beech (Fagus sylvatica), with the age of the stand being 40-90 years. Excluded were the areas of nature conservation, water protection, special biotopes (e.g., capercaillie habitats), protected forests, other study sites, as well as previously limed areas. With regard to the tree vitality, severely damaged stands with tree needle loss $>40 \%$ were also excluded from selection. Directly adjacent to an untreated "control" plot a "limed" plot was established by applying a calcium carbonate $\mathrm{CaCO}_{3}$ in mixture with 4-8\% MgO, 3\% $\mathrm{P}_{2} \mathrm{O}_{5}$ and 6-10\% $\mathrm{K}_{2} \mathrm{O}$ ("Kohlensaurer Kalk 121/123/127", lime grade $95 \%<3.15 \mathrm{~mm}$ and $70 \%<1.0 \mathrm{~mm}$ ) from autumn 1983 until early winter 1984 . The dose was established site-specific according to the $\mathrm{pH}$, humus form and tree species surveyed in 1983, and was no higher than $3.5 \mathrm{Mg} \mathrm{ha}^{-1}$, in most cases between 2.5 and $3 \mathrm{Mg} \mathrm{ha}^{-1}$. This comparably low dosage was chosen in order to avoid overly high mobilization of the humus layer and undesirable nutrient leaching in the groundwater and surface waters. This also meant that any changes in the soil acidity status were expected to progress slowly over several years.

In 2003 a second treatment of $6 \mathrm{Mg} \mathrm{ha}^{-1}$ dolomite lime with $55 \% \mathrm{CaCO}_{3}$ and $35 \% \mathrm{MgCO}_{3}$ ("CaMg$\left(\mathrm{CO}_{3}\right)_{2} 55 / 35$ ", lime grade $90 \%<0.1 \mathrm{~mm}$ ) was applied. The dolomite lime was seen to buffer acid deposition effectively and to react slower than the previously applied calcium carbonate mixture, with milder effects on humus, and was therefore chosen to be applied in larger doses.

It is important to note that the study sites have been considered as praxis-fertilization trials, meaning that the scientific investigations have accompanied the regular forest management practices (moderate thinning of stands, storm damage response, natural regeneration or planting, etc.). A recent comprehensive inventory of these sites was conducted in 2015 and their updated description is shown in Table 1. A map of study site locations is shown in Appendix A (Figure A1). 
Table 1. Study sites and their key parameters in 2015.

\begin{tabular}{|c|c|c|c|c|c|c|c|c|c|c|c|c|}
\hline \multirow{2}{*}{ Site } & \multirow{2}{*}{$\begin{array}{c}\text { Latitude } \\
\quad\left({ }^{\circ}\right)\end{array}$} & \multirow{2}{*}{$\begin{array}{l}\text { Longitude } \\
\left({ }^{\circ}\right)\end{array}$} & \multirow{2}{*}{$\begin{array}{c}\text { Altitude } \\
\text { (m asl) }\end{array}$} & \multicolumn{2}{|c|}{ Plot Size (ha) } & \multirow{2}{*}{ Substrate } & \multirow{2}{*}{ Soil Type ${ }^{1}$} & \multirow{2}{*}{ Texture $^{2}$} & \multirow{2}{*}{$\begin{array}{l}\text { Humus } \\
\text { Type }^{3}\end{array}$} & \multirow{2}{*}{$\begin{array}{l}\text { Stand } \\
\text { Type }^{4}\end{array}$} & \multirow{2}{*}{$\begin{array}{c}\text { Stand } \\
\text { Age }\end{array}$} & \multirow{2}{*}{ Grouping 5} \\
\hline & & & & Control & Limed & & & & & & & \\
\hline $\begin{array}{c}\text { Bad } \\
\text { Waldsee }\end{array}$ & $47^{\circ} 50^{\prime}$ & $9^{\circ} 41^{\prime}$ & 580 & 4 & 22 & Glacial till & cambisol & LS & $\begin{array}{l}\text { mull - } \\
\text { moder } \\
\text { mull }\end{array}$ & PI-FA & 70 & G1 \\
\hline Ellwangen & $49^{\circ} 01^{\prime}$ & $10^{\circ} 10^{\prime}$ & 490 & 10 & 15 & Sandstone & stagnosol & SL & mull & PI & 100 & G1 \\
\hline $\begin{array}{l}\text { Freuden- } \\
\text { stadt }\end{array}$ & $48^{\circ} 26^{\prime}$ & $8^{\circ} 25^{\prime}$ & 740 & 8 & 21 & Sandstone & cambisol & SL & $\begin{array}{l}\text { mull - mor } \\
\text { moder }\end{array}$ & AB-PI & 100 & G1 \\
\hline Heidelberg & $49^{\circ} 30^{\prime}$ & $8^{\circ} 47^{\prime}$ & 490 & 2 & 3 & Sandstone & podsol & SL & mull & PI & 70 & G1 \\
\hline $\begin{array}{l}\text { Ochsen- } \\
\text { hausen }\end{array}$ & $48^{\circ} 06^{\prime}$ & $10^{\circ} 02^{\prime}$ & 620 & 5 & 17 & $\begin{array}{c}\text { Periglacial } \\
\text { gravel }\end{array}$ & cambisol & $\mathrm{L}$ & $\begin{array}{l}\text { mull - } \\
\text { moder } \\
\text { mull }\end{array}$ & PI & 90 & G1 \\
\hline $\begin{array}{l}\text { Herzogen- } \\
\text { weiler }\end{array}$ & $48^{\circ} 01^{\prime}$ & $8^{\circ} 20^{\prime}$ & 950 & 8 & 20 & Sandstone & stagnosol & LS-SL & $\begin{array}{c}\text { mull - } \\
\text { moder } \\
\text { mull }\end{array}$ & AB-PI & 90 & G2 \\
\hline Horb & $48^{\circ} 28^{\prime}$ & $8^{\circ} 32^{\prime}$ & 630 & 8 & 21 & Sandstone & cambisol & LS & mull & AB-PI & 100 & G2 \\
\hline Hospital & $48^{\circ} 07^{\prime}$ & $9^{\circ} 41^{\prime}$ & 650 & 3 & 5 & Glacial till & stagnosol & SiL-L & $\begin{array}{l}\text { mull - mor } \\
\text { moder }\end{array}$ & PI-FA & 110 & G2 \\
\hline Wangen & $47^{\circ} 47^{\prime}$ & $9^{\circ} 45^{\prime}$ & 710 & 6 & 22 & Glacial till & umbrisol & SiL-L & $\begin{array}{l}\text { mor } \\
\text { moder }\end{array}$ & PI & 100 & G2 \\
\hline Weithard & $47^{\circ} 58^{\prime}$ & $9^{\circ} 17^{\prime}$ & 630 & 1 & 6 & Glacial till & stagnosol & CL-L & $\begin{array}{l}\text { mull - mor } \\
\text { moder }\end{array}$ & PI & 100 & G2 \\
\hline
\end{tabular}

${ }^{1}$ dominating soil type according to FAO 2014 (World Reference Base For Soil Classification); ${ }^{2}$ mean textural classes according to FAO [24] (pp. 25-29): LS = Loamy sand, SL = Sandy loam, $\mathrm{L}=$ Loam, $\mathrm{SiL}=$ Silty loam, $\mathrm{CL}=$ Clay loam; ${ }^{3}$ dominating humus forms according to Ad-hoc-Arbeitsgruppe Boden (German soil classification) [25] (pp. 303-310); ${ }^{4} \mathrm{PI}=\mathrm{Picea}$ abies, AB-PI $=$ mixed Abies alba and Picea abies, PI-FA= mixed Picea abies and Fagus sylvatica; ${ }^{5}$ Grouping according to K-means Cluster Analysis (see statistical analyses). 


\subsection{Soil Sampling and Laboratory Methods}

The sampling methods of the different sampling periods of 1985-2015 are described in Table 2

Table 2. Soil sampling design in the 1980s (as described in Wilpert et al. [23]), 2003, 2010 and 2015.

\begin{tabular}{|c|c|c|c|c|}
\hline & 1985/86 and 1989 & 2003 & 2010 & 2015 \\
\hline $\begin{array}{l}\text { Sample layout } \\
\text { within plot }\end{array}$ & $\begin{array}{l}\text { 3-10 (O-layer) and } \\
\text { 6-10 (mineral soil) } \\
\text { samples in } 10 \mathrm{~m} \\
\text { distance along a } \\
\text { random diagonal } \\
\text { line }\end{array}$ & $\begin{array}{c}1 \text { sample at } 5 \\
\text { randomly distributed } \\
\text { points plus } 5 \text { samples } \\
\text { at } 0,80,160,240 \text { and } \\
320 \text { gradian in } 5 \mathrm{~m} \\
\text { distance from a soil } \\
\text { profile }\end{array}$ & $\begin{array}{c}1 \text { sample at } 5 \\
\text { randomly } \\
\text { distributed points }\end{array}$ & $\begin{array}{c}1 \text { sample at } 5 \\
\text { randomly } \\
\text { distributed points }\end{array}$ \\
\hline $\begin{array}{l}\text { Sampled soil } \\
\text { layers }\end{array}$ & $\begin{array}{l}\text { O-layer }{ }^{\mathrm{a}} \\
0-4 \mathrm{~cm}^{\mathrm{b}} \\
5-10 \mathrm{~cm}^{\mathrm{a}}\end{array}$ & $\begin{array}{l}\text { O-layer }{ }^{\mathrm{c}} \\
0-5 \mathrm{~cm}^{\mathrm{d}} \\
5-10 \mathrm{~cm}^{\mathrm{d}} \\
10-30 \mathrm{~cm}^{\mathrm{d}} \\
30-60 \mathrm{~cm}^{\mathrm{d}}\end{array}$ & $\begin{array}{l}\text { O-layer }{ }^{\mathrm{c}} \\
0-5 \mathrm{c} \mathrm{m}^{\mathrm{d}} \\
5-10 \mathrm{~cm}^{\mathrm{d}} \\
10-30 \mathrm{~cm}^{\mathrm{d}} \\
30-60 \mathrm{~cm}^{\mathrm{d}}\end{array}$ & $\begin{array}{l}\text { O-layer }{ }^{c} \\
0-5 \mathrm{~cm}^{\mathrm{d}} \\
5-10 \mathrm{~cm}^{\mathrm{d}} \\
10-20 \mathrm{~cm}^{\mathrm{d}} \\
20-30 \mathrm{~cm}^{\mathrm{d}} \\
30-60 \mathrm{~cm}^{\mathrm{d}}\end{array}$ \\
\hline Instrument & $\begin{array}{c}\text { a: scraper } \\
\text { b: } 100 \mathrm{~cm}^{3} \text { soil } \\
\text { sample ring }\end{array}$ & $\begin{array}{c}\text { c: } 200 \mathrm{~cm}^{3} \text { soil } \\
\text { sample ring } \\
\text { d: Eijkelkamp root } \\
\text { auger }(\text { diameter } 8 \mathrm{~cm} \text {, } \\
\text { length } 15 \mathrm{~cm})\end{array}$ & $\begin{array}{l}\text { c: } 200 \mathrm{~cm}^{3} \text { soil } \\
\text { sample ring } \\
\text { d: Eijkelkamp root } \\
\text { auger (diameter } 8 \\
\mathrm{~cm} \text {, length } 15 \mathrm{~cm} \text { ) }\end{array}$ & $\begin{array}{c}\text { c: } 200 \mathrm{~cm}^{3} \text { soil } \\
\text { sample ring } \\
\text { d: Eijkelkamp root } \\
\text { auger (diameter } 8 \\
\mathrm{~cm} \text {, length } 15 \mathrm{~cm} \text { ) }\end{array}$ \\
\hline No. of replicates & 1 mixed sample & 1 mixed sample & $\begin{array}{l}4 \text { individual } \\
\text { samples }\end{array}$ & $\begin{array}{l}5 \text { individual } \\
\text { samples }\end{array}$ \\
\hline
\end{tabular}

The first sampling period was 1985 and 1986, a further sampling campaign was completed in 1989/90. Three to ten samples of O-layer and six to ten samples of the mineral soil were collected and then mixed into a single sample for the laboratory analysis. The results comparing the development at control and limed plots between these two sampling campaigns have been published in Wilpert et al. [23] (pp. 30-45). The control plot $\mathrm{pH}-\mathrm{KCl}$ in mineral topsoil was $\mathrm{pH}$ 3.0, i.e., in the $\mathrm{Al}$ and $\mathrm{Al}-\mathrm{Fe}$ buffer range, meanwhile at limed plots it had increased by average $0.9 \mathrm{pH}$ units in 1985/86 and $0.2 \mathrm{pH}$ units by 1989/90 in 0-4 cm topsoil, while in $4-10 \mathrm{~cm}$ topsoil only by $1989 / 90$ an increase by $0.2 \mathrm{pH}$ units was observed. The $\mathrm{pH}-\mathrm{H}_{2} \mathrm{O}$ was reported to be $0.5-1 \mathrm{pH}$ units higher than $\mathrm{pH}-\mathrm{KCl}$, with $10-20 \%$ less change after treatment. While at control plots the O-layer thickness tended to increase, at limed plots it had decreased, and liming had increased the variability of C-content in 4-10 $\mathrm{cm}$ mineral soil with little change in average $\mathrm{C}$-content. Control plot exchangeable cations (CEC) and exchangeable cations were analyzed only in 1989/90 samples, where base saturation improved significantly by $17 \%$ after lime treatment (though with high variance) especially exchangeable $\mathrm{Ca}$ and slightly less exchangeable $\mathrm{Mg}$, with little change in exchangeable $\mathrm{K}$. Meanwhile exchangeable $\mathrm{Al}$ and $\mathrm{H}$ had decreased. Limed plot CEC had overall increased by $14 \%$.

The second sampling was carried out in April until October 2003, i.e., twenty years after the first liming and before the second treatment campaign. A soil sample per depth class was taken at five randomly distributed points across a plot as well as in five directions from an established soil profile, then mixed into a single sample. In March-October 2010-seven years after the second liming event-soil sampling was done at four randomly distributed points per treatment plot. The final soil sampling campaign was carried out in March until June 2015-twelve years since the second lime application-at five randomly distributed points per plot.

The soil samples were dried at $60{ }^{\circ} \mathrm{C}$ and ground in a mill with a $2 \mathrm{~mm}$ sieve.

The following soil chemical parameters were considered in our investigation: $\mathrm{pH}-\mathrm{H}_{2} \mathrm{O}$ and $\mathrm{pH}-\mathrm{KCl}$ were measured with a glass electrode in 1:5 (mineral soil) and 1:10 (O-layer) solution with $\mathrm{H}_{2} \mathrm{O}$ and $1 \mathrm{M} \mathrm{KCl}$; mineral soil exchangeable cations $\mathrm{Ca}^{2+}, \mathrm{Mg}^{2+}, \mathrm{K}^{+}, \mathrm{Al}^{3+}, \mathrm{Fe}^{3+}\left(\mu \mathrm{mol}_{\mathrm{c}} \mathrm{g}^{-1}\right)$ and their sum CEC (including cations $\mathrm{Na}^{+}, \mathrm{Mn}^{2+}$ and $\mathrm{H}^{+}$) as well as the calculated mineral soil base saturation 
(\%) were determined via percolation with $1 \mathrm{M} \mathrm{NH}_{4} \mathrm{Cl}$-solution and extract analysis with ICP-OES; total $\mathrm{N}$ and total $\mathrm{C}\left(\mathrm{g} \mathrm{kg}^{-1}\right)$ were measured in dry combustion (Wösthoff in 1980s, Leco CN 2000 in 2003, Vario Max Elementar in 2010-2015) and C/N ratio was calculated; total Ca, Mg, K, Al and $\mathrm{Fe}\left(\mathrm{g} \mathrm{kg}^{-1}\right)$ in the O-layer only were determined in aqua regia extract; organic layer stocks $\left(\mathrm{t} \mathrm{ha}^{-1}\right)$ were calculated form dried soil samples of defined sampled area. The methodology of our laboratory analyses was according to "Handbuch Forstliche Analytik" ("Handbook of Forest Analysis"; HFA) by the Forest Analysis Advisory Committee (GAFA) [26-28]. Our original data is available as Tables S1-S3 in Supplementary Materials.

It was assumed that the mineral soil bulk density remained stable during the different sampling periods at the study sites, and therefore the element concentrations may be directly compared between the sampling years and between the directly adjacent treatment variants without considering element stocks.

The element concentrations in 2015 were aggregated from 10-20 to 20-30 cm depth samples into $10-30 \mathrm{~cm}$ according to fine earth stocks for better comparison with the previous sampling periods. $\mathrm{pH}$ values were aggregated after conversion into $\mathrm{H}^{+}$concentration $\left(\mathrm{mol} \mathrm{L}^{-1}\right)$ and subsequent reconversion into $\mathrm{pH}$. Bulk density and fine earth stocks were estimated only in 2015 from soil sample volume, weight and coarse soil fraction.

\subsection{Statistical Analysis}

The statistical evaluations were conducted using R 3.6.3 (R Core Team 2019).

First of all, a K-means cluster analysis (CA) was conducted in order to explore the similarity of sites by their soil chemical parameters at 0-30 $\mathrm{cm}$ control plot mineral soil (aggregated, sampling campaign 2015, $n=49$ ), whereby the exchangeable cation as well as $C_{\text {tot }}$ and $N_{\text {tot }}$ concentrations were calculated in stocks ( $\mathrm{t} \mathrm{ha}^{-1}$ ) according to fine earth stocks for better site comparability. The optimal number of clusters, i.e., groups of sites was determined to be 2; Group 1 contains the study sites "Bad Waldsee", "Ellwangen", "Freudenstadt", "Heidelberg" and "Ochsenhausen" ( $n=5)$, and Group 2 the sites "Herzogenweiler", "Horb", "Hospital", "Wangen" and "Weithard" ( $n=5$; Table 1). Additionally a principal component analysis (PCA) was run in order to confirm the CA results, as well as determine the most relevant soil chemical principal components (PC) of these site groups. The first two PCs explained $64.9 \%$ of the variability in data, and were $\mathrm{pH}-\mathrm{H}_{2} \mathrm{O}, \mathrm{pH}-\mathrm{KCl}$ and $\mathrm{K}^{+}$( $\mathrm{t} \mathrm{ha}^{-1}$; $\left.\mathrm{PC}-1\right), \mathrm{C}_{\text {tot }}$ $\left(\mathrm{t} \mathrm{ha}^{-1}\right)$ and CEC ( $\mu \mathrm{mol}_{\mathrm{c}} \mathrm{g}^{-1}$; PC-2; Figure 1).

Group 1 (G1) includes the sites with predominantly "sandy soils" and is characterized with lower $\mathrm{CEC}$, lower $\mathrm{C}_{\text {tot }}$ stocks, lower $\mathrm{K}^{+}$stocks and higher $\mathrm{Al}^{3+}$ stocks in the upper mineral soil compared to Group 2 (G2) of predominantly finer textured "silty/clay loam soils". For both study site groups $\mathrm{pH}-\mathrm{H}_{2} \mathrm{O}$ of $4.0-4.4$ was similar in $0-30 \mathrm{~cm}$ mineral soil, whereas $\mathrm{pH}-\mathrm{KCl}$ was 3.3-3.6 at $\mathrm{G} 1$ and 3.5-3.7 at $\mathrm{G} 2$ sites, i.e., comparably higher.

The statistical analysis was applied to both site groups separately. Due to small sample size in the sampling campaigns ( $n<30$ per depth class) as well as a lack of normal distribution in some of the data, non-parametric statistical tests were chosen. In order to compare the difference in group-means between sampling years (separately for control and lime treatments) Friedman test for repeated (dependent) measurements was applied. To find differences between control and lime treatments within a sampling year Mann-Whitney $U$ test for independent samples was used. The significance level was chosen $p<0.05$. 


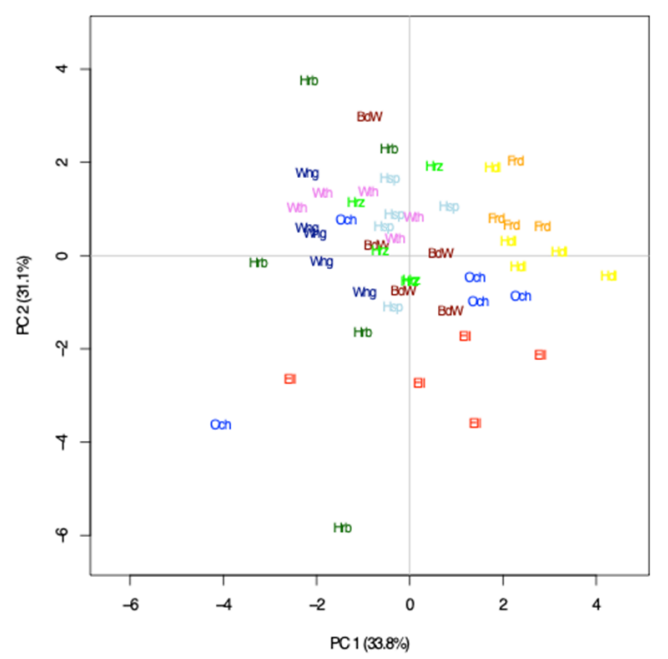

(a)

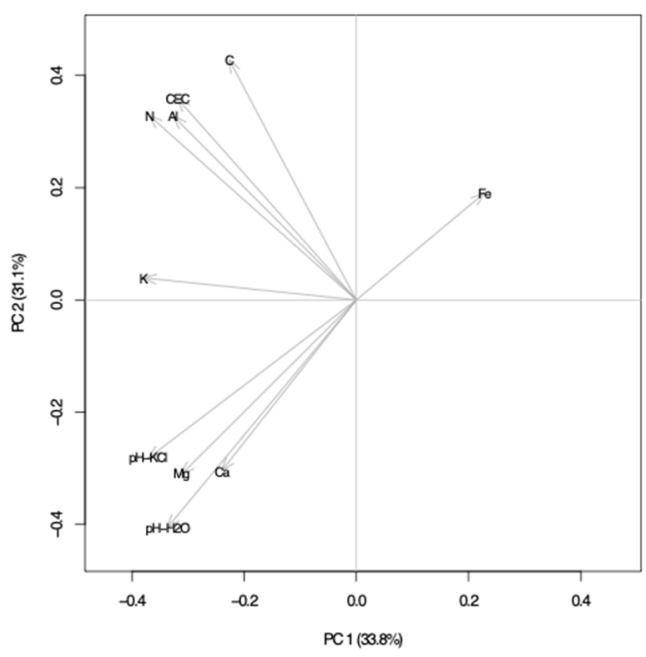

(b)

Figure 1. Principal component analysis (PCA) to characterize study site grouping parameters: (a) study sites and (b) principal components.

To estimate the natural recovery as well as the effects of lime application over time, i.e., the difference between two sampling periods within a study site group, a relative response ratio $\left(R R_{r}\right)$ was calculated for each of the relevant site parameters based on methodology in Hedges et al. [29] and Reid and Watmough [17]:

$$
\mathrm{RR}_{\mathrm{r}}=(\mathrm{t} 2 / \mathrm{t} 1)-1,
$$

where $\mathrm{t} 1=$ site plot average (arithmetic mean) in previous sampling period, $\mathrm{t} 2=$ site plot average in following sampling period. In case of already relative $(\mathrm{C} / \mathrm{N})$, log-transformed $(\mathrm{pH})$ and discontinuous (base saturation) variables an absolute $\mathrm{RR}_{\mathrm{a}}$ was calculated as difference between previous and following sampling year or limed and control treatment.

$$
\mathrm{RR}_{\mathrm{a}}=\mathrm{t} 2-\mathrm{t} 1
$$

\section{Results}

Since the 1980s sampling design and data set was not comparable with the subsequent campaigns from 2003 until 2015, we were not able to analyze statistically the changes in soil chemical properties of the entire measured soil profile of our studied sites for the period 1980s until 2003. Nevertheless with the sampling data of 2003 we can evaluate the liming effects in this initial study period on soil properties with the direct comparison of control and limed plots. From 2003 on we can describe the development of soil chemical properties with respect to liming effects in great detail. In this context we will first of all present the changes in soil acidity status with focus on $\mathrm{pH}$ values, base saturation and cation exchange capacities as well as the exchangeable cations concentrations. Secondly the development of soil nutrient status with focus on carbon and nitrogen are outlined. A complete list of parameter means (with standard deviations) as they developed over time and after lime treatment is available as Table S4 (G1) and S5 (G2) in Supplementary Materials. The parameter response ratio (RR) means, SD and ranges are fully detailed in Tables S6 (G1) and S7 (G2) of Supplementary Materials.

\subsection{Liming Effects in 2003}

In 2003 - twenty years after the first lime treatment in 1983-no significant differences could be seen in soil $\mathrm{pH}$ or base saturation between the control and limed plots. The mean values at limed plots tended to be higher for both parameters, especially in the O-layer $(\mathrm{pH})$ and $0-5 \mathrm{~cm}$ mineral soil (BS), 
however the confidence intervals of both control and lime treatment overlap. Similarly, sum CEC by 2003 was comparable throughout the entire soil profile also. G2 site $0-5 \mathrm{~cm}$ mineral soil sample exchangeable $\mathrm{Ca}$ as well as $\mathrm{C}_{\text {tot }}$ and $\mathrm{N}_{\text {tot }}$ were significantly increased-a potential residual effect of lime application in 1983-yet even here the increase in CEC was only slight and not significant. G1 site limed plot O-layer total $\mathrm{Al}$ and total Fe concentrations were significantly higher compared to control, although again without any notable influence on the $\mathrm{pH}$ or CEC.

\subsection{Soil Acidity Status Development between 2003 and 2015}

\subsection{1. $\mathrm{pH}$ Values}

A tendency towards natural recovery of soil $\mathrm{pH}-\mathrm{H}_{2} \mathrm{O}$ was observed between 2003 and 2015 in the entire soil profile of G1 study sites (Figure 2a) from group average $\mathrm{pH} 3.5$ to $\mathrm{pH} 3.9$ in the O-layer, and from $\mathrm{pH} 3.5-4.3$ to $\mathrm{pH} 3.9-4.6$ in the $0-60 \mathrm{~cm}$ mineral soil. The rate of response (RR) was significant in $0-5 \mathrm{~cm}$ and $10-60 \mathrm{~cm}$ mineral soil by $2010\left(\mathrm{RR}_{\mathrm{a}} 0.1-0.2 \mathrm{pH}\right.$ units), and in the O-layer by $2015\left(\mathrm{RR}_{\mathrm{a}} 0.3 \mathrm{pH}\right.$ units) (Figure 3a). At G2 sites (Figure $2 b)$ the natural recovery was significant in O-layer $\left(R_{a} 0.2 \mathrm{pH}\right.$ units) and 10-30 cm mineral soil ( $R_{\mathrm{a}} 0.3 \mathrm{pH}$ units) between 2003 and 2010. By 2015, however, this recovery was no longer significant. The $\mathrm{G} 2$ group average shifted from $\mathrm{pH} 3.7$ to $\mathrm{pH} 3.9$ in the O-layer, and from pH 3.6-4.3 to pH 3.8-4.6 in the 0-60 cm mineral soil in the period from 2003 until 2015.
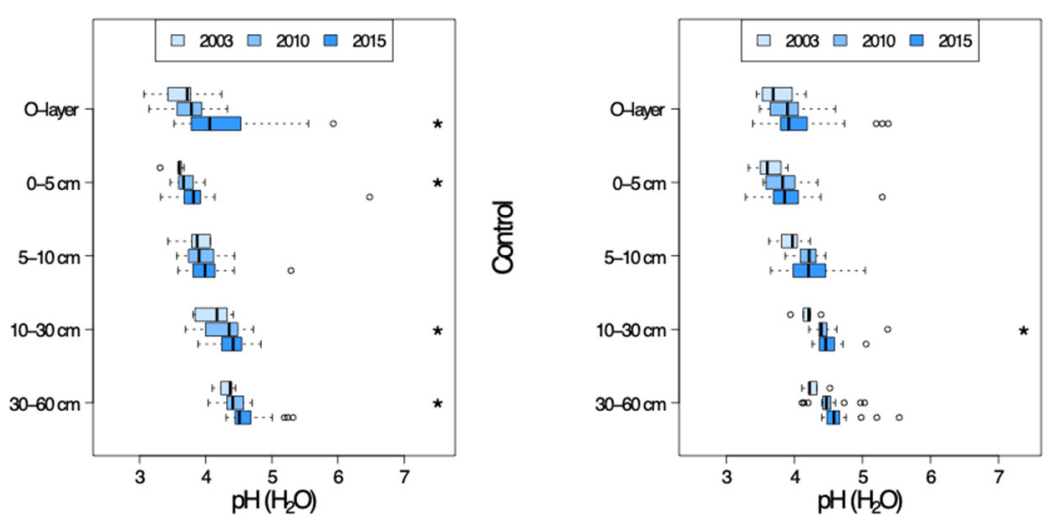

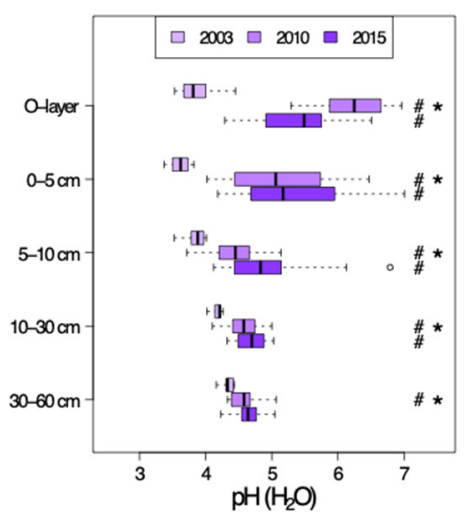

(a)

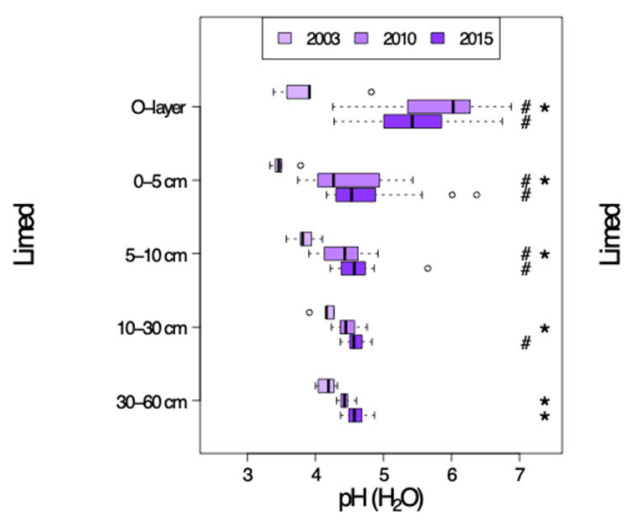

(b)

Figure 2. $\mathrm{pH}-\mathrm{H}_{2} \mathrm{O}$ in the soil profiles of control and lime treated plots in 2003-2015. (a) G1 study sites. (b) G2 study sites. \#-limed plots significantly different from control; *-significant differences between current and previous sampling campaign. 


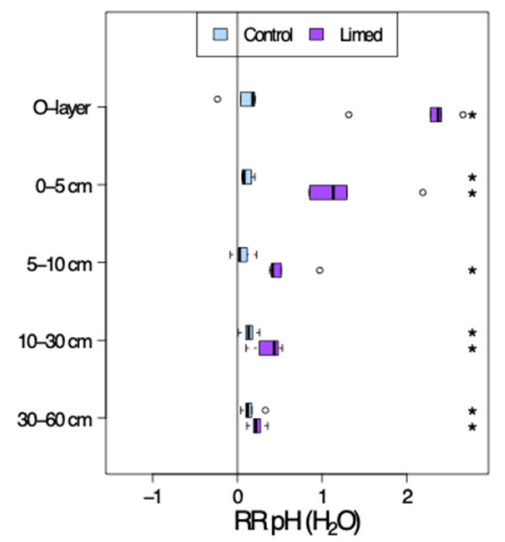

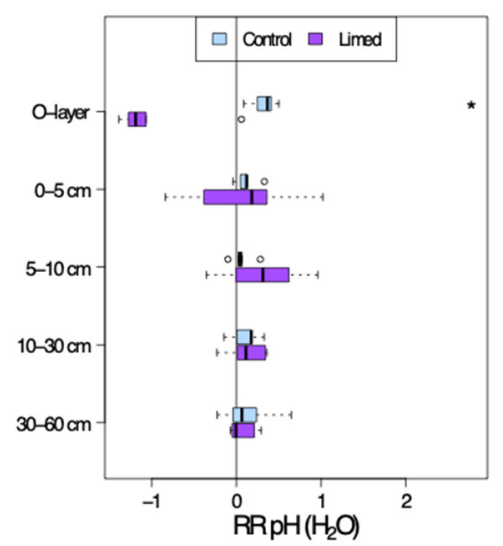

(a)
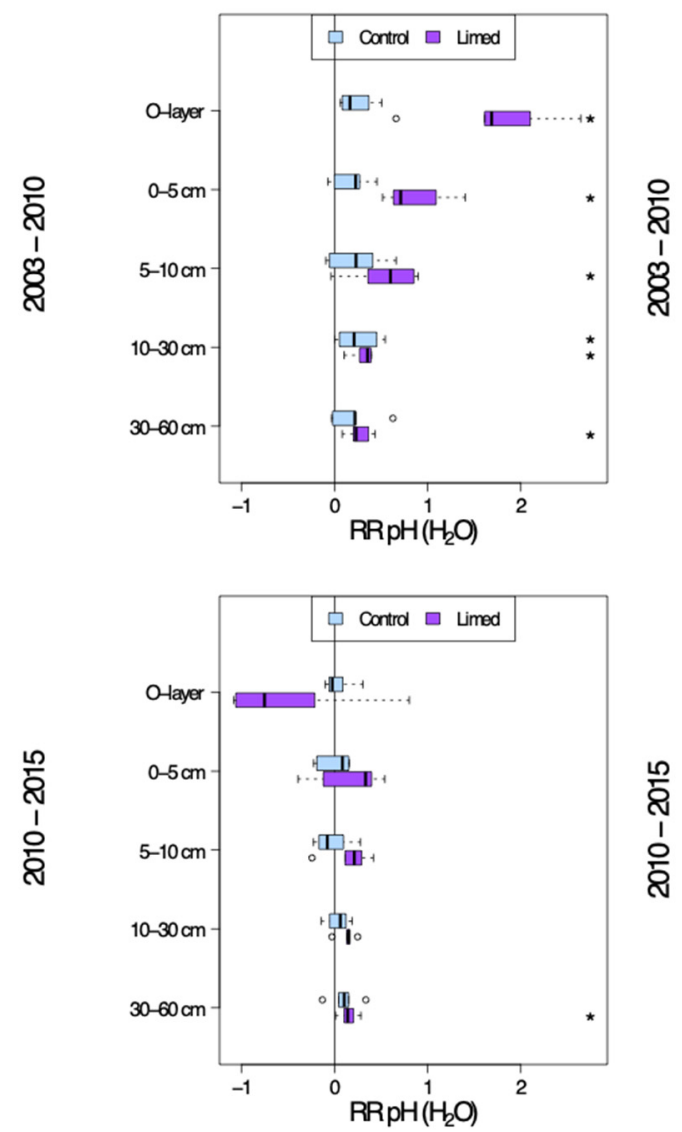

(b)

Figure 3. $\mathrm{pH}-\mathrm{H}_{2} \mathrm{O}$ site average response ratio $\left(\mathrm{RR}_{\mathrm{a}}\right)$ seven years after (2003-2010) and twelve years after the second lime treatment (2010-2015). (a) G1 study sites. (b) G2 study sites. *—significant differences between current and previous sampling campaign.

At lime treated plots $\mathrm{pH}-\mathrm{H}_{2} \mathrm{O}$ has been increasing significantly in the entire soil profile of both G1 and G2 sites between 2003 and 2010, i.e., in the first 7 years since second lime application by $0.2-2.2 \mathrm{pH}$ units at G1 and 0.2-1.7 pH units at G2 - the RR decreasing with depth (Figure 3a,b). Between 2010 and 2015 the rise in limed mineral soil $\mathrm{pH}-\mathrm{H}_{2} \mathrm{O}$ was again comparable to that of control plots with group average 0.1-0.3 (G1) and 0.1-0.2 (G2) pH unit increase in the mineral soil profile, although in the O-layer the $\mathrm{pH}$ is once again decreasing by mean 1.0 (G1) and 0.5 (G2) pH units. While the difference between the control and limed plots was significant in all G1 measured soil profile depths in 2010, the treatment effect has lost its significance in 30-60 cm mineral soil by 2015, i.e., the period 7-12 years since the last lime application. At G2 sites the liming effect reached significance only down to $10 \mathrm{~cm}$ mineral soil by 2010, moving further down in the soil profile to $30 \mathrm{~cm}$ mineral soil by 2015 .

Similar development in both natural recovery and liming effects over time was seen also in $\mathrm{pH}-\mathrm{KCl}$ (see Appendix B Tables A3 and A4). The effect of lime treatment was even more pronounced in the O-layer and topsoil 0-5 cm, but overall the limed plots had a significant treatment effect only down to $10 \mathrm{~cm}$ topsoil at $\mathrm{G} 1$ and just down to $5 \mathrm{~cm}$ at G2.

\subsubsection{Base Saturation}

From 2003 on a tendency towards slight natural recovery of base saturation (BS) was seen across all study sites, although significant only in case of G2 site $0-5 \mathrm{~cm}$ topsoil (Figures 4 and 5). The average $R R_{a}$ in the $0-60 \mathrm{~cm}$ soil profile was $1-5 \%$ in $2003-2010$, and $4-9 \%$ (G1) and $0.5-7 \%$ (G2) in 
2010-2015. Except for some of the sites of G1 in 2015, the control plot base saturation remained below $20 \%$, i.e., poor.

The liming effect after 2003 was especially strong at G1 sites with an average 30-60\% significant increase in $0-10 \mathrm{~cm}$ topsoil BS and $7-11 \%$ in $10-60 \mathrm{~cm}$ in the first 7 years after second lime application. This liming effect continued-with a $0-10 \mathrm{~cm}$ topsoil reduction in $\mathrm{RR}_{\mathrm{a}}$ to just $6-20 \%$ and $10-60 \mathrm{~cm} R R_{a}$ 4-8\%-also until 2015. At G2 sites the lime treatment effect was comparably lower: $15-30 \%$ in the 0-10 cm topsoil and 4-7\% in 10-60 cm between 2003 and 2010. By 2015 the $R_{a}$ had dropped in both the $0-10 \mathrm{~cm}$ topsoil to $7-15 \%$, as well as in the deeper soil horizons $10-60 \mathrm{~cm}$ to just a $1-3 \%$ increase in group average BS. Compared to the control plots both G1 and G2 limed plot BS was significantly higher in the entire mineral soil profile both 7 and 12 years since the second lime application: $75-80 \%$ in $0-5 \mathrm{~cm}, 35-55 \%$ in $5-10 \mathrm{~cm}, 15-25 \%$ in $10-30 \mathrm{~cm}$ and $12-15 \%$ in $30-60 \mathrm{~cm}$ mineral soil. G2 limed plot base saturation was generally lower: $45-55 \%$ in $0-5 \mathrm{~cm}, 20-30 \%$ in $5-10 \mathrm{~cm}, 11-12 \%$ in $10-30 \mathrm{~cm}$ and $9-12 \%$ in $30-60 \mathrm{~cm}$ mineral soil.
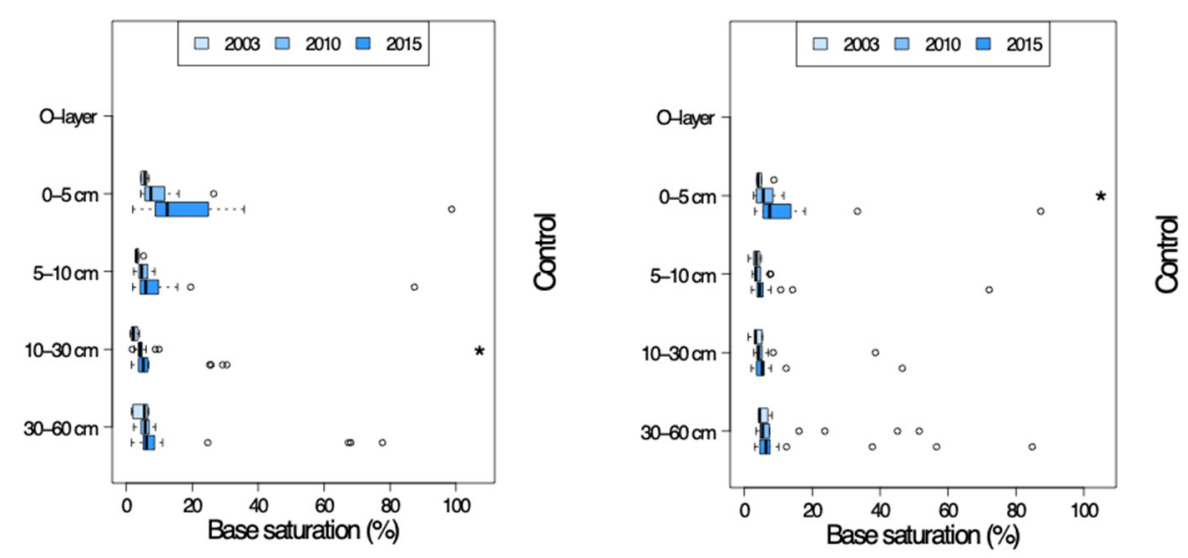

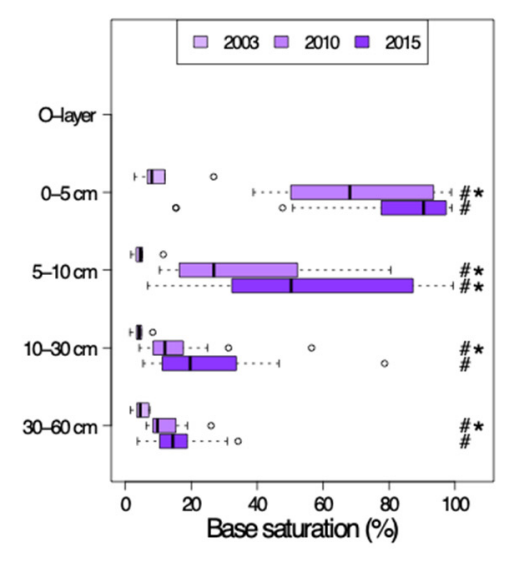

(a)

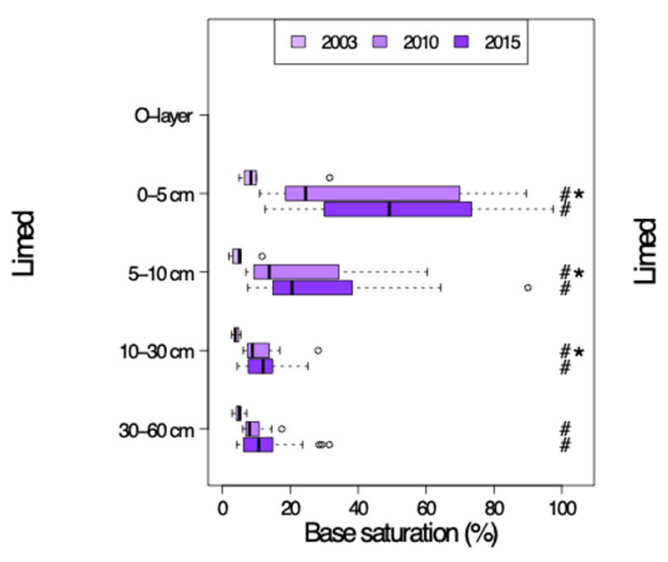

(b)

Figure 4. Base saturation in the soil profiles of control and lime treated plots in 2003-2015. (a) G1 study sites. (b) G2 study sites. \#-limed plots significantly different from control; * - significant differences between current and previous sampling campaign. 

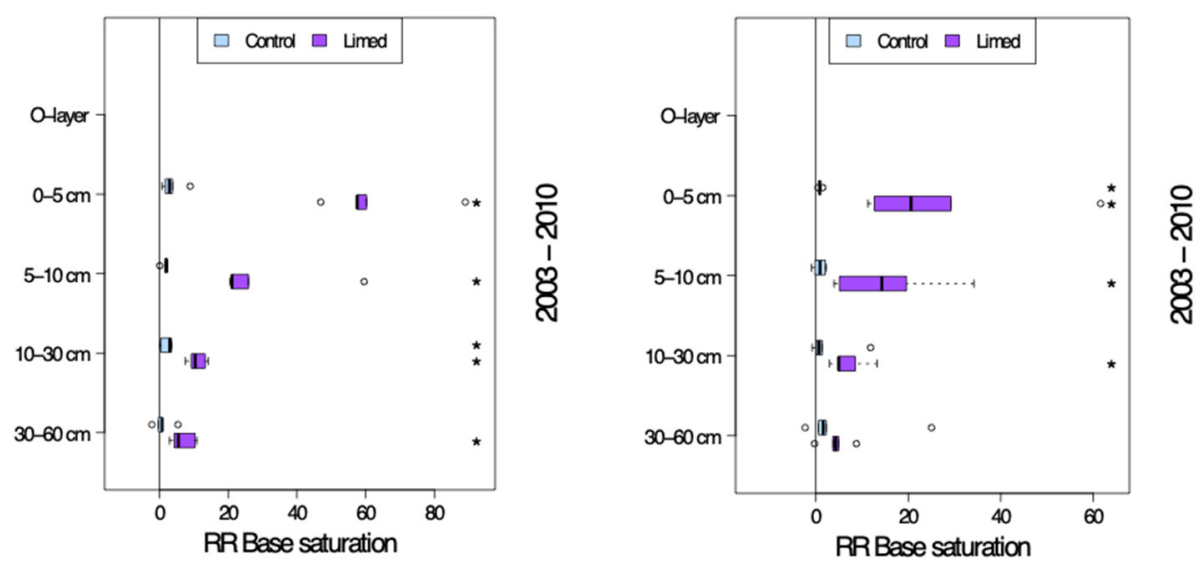

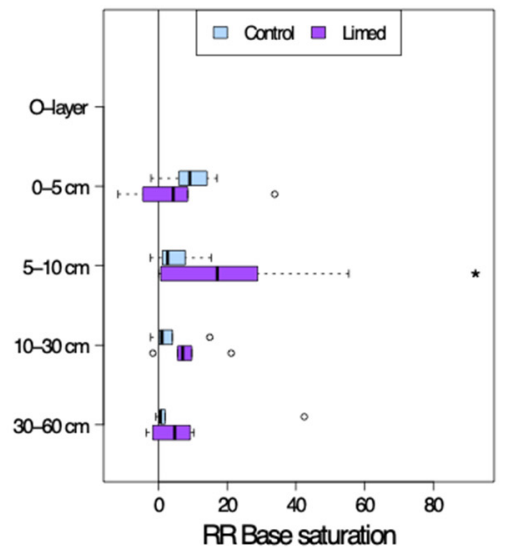

(a)

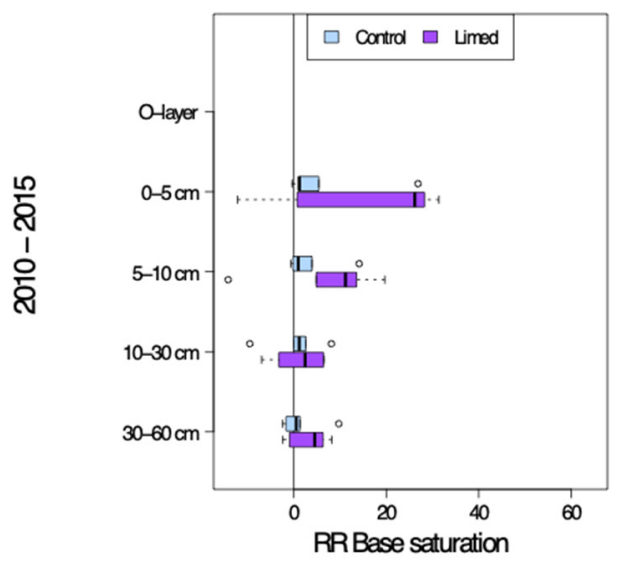

(b)

Figure 5. Base saturation site average response ratio $\left(R R_{a}\right)$ seven years after (2003-2010) and twelve years after the second lime treatment (2010-2015). (a) G1 study sites. (b) G2 study sites. *—significant differences between current and previous sampling campaign.

\subsubsection{Cation Exchange Capacities}

From 2003 the sum of the control plot exchangeable cations (CEC; Figure 6) has remained stable throughout the following sampling periods in the mineral soil profiles at both G1 and G2 study sites, with no significant differences between the sampling years.

At limed plots, the 0-5 cm upper topsoil CEC at G1 sites was significantly higher in 2010 (RR 0.73) - mainly due to greatly increased availability of $\mathrm{Ca}$ and $\mathrm{Mg}$ base cations, and despite notably decreased $\mathrm{Al}$ and Fe-III acid cation concentrations. At G1 5-30 cm this similar but less pronounced increase in base cations appeared to balance out the decrease in acid cations so that the CEC did not change significantly at the limed plots. No significant lime treatment effect on total CEC could be observed in the topsoil G2 sites (although from 2010 to 2015 CEC did increase significantly in $0-5 \mathrm{~cm}$ topsoil, $\mathrm{RR}_{\mathrm{r}} 0.15$ ) where $\mathrm{Ca}$ and $\mathrm{Mg}$ cation concentrations increased distinctly and the acid cations decreased. Since the base cation increase reached down to $60 \mathrm{~cm}$ mineral soil, and acid cation concentration only decreased in the upper $10 \mathrm{~cm}$ due to liming, G2 limed plot CEC became significantly greater than control progressively with time. 

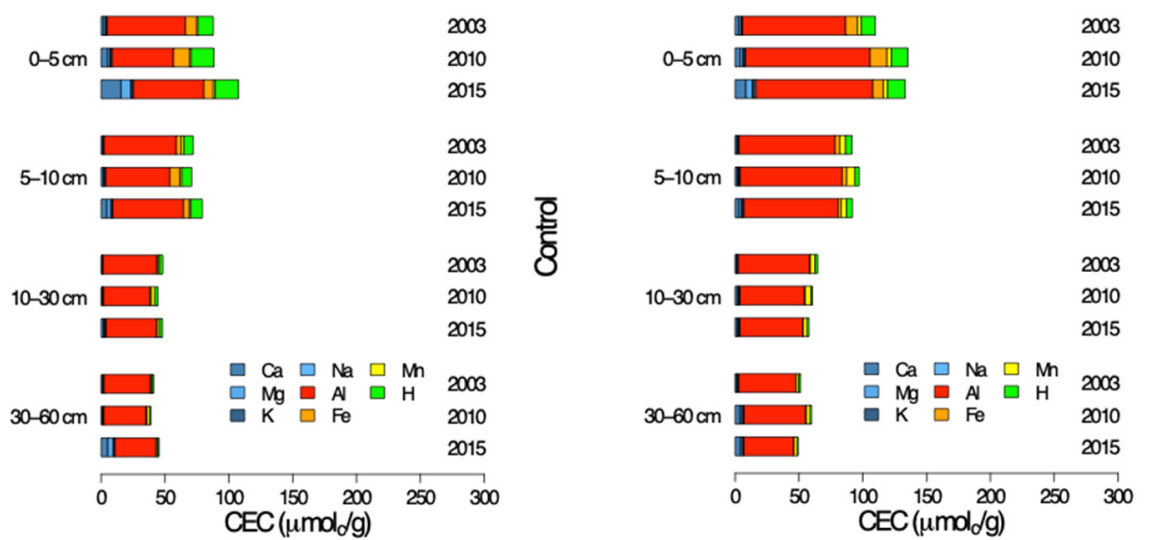

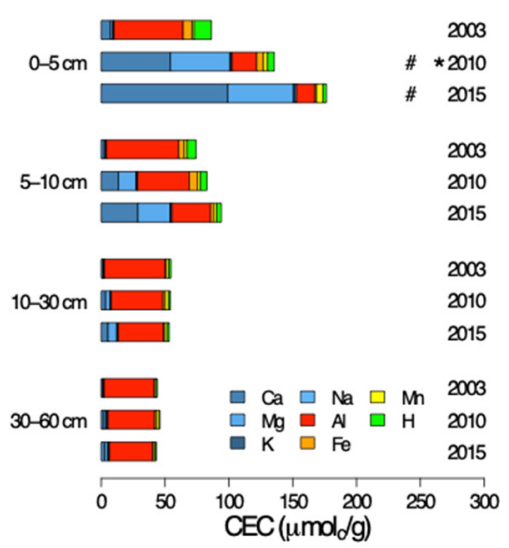

(a)

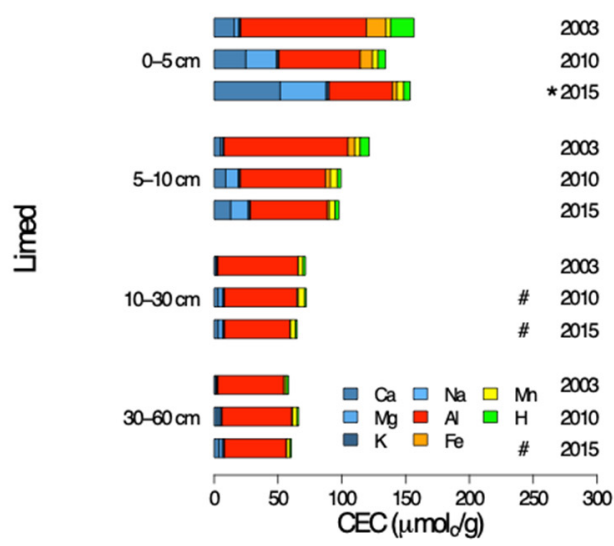

(b)

Figure 6. Control plot exchangeable cations (CEC) in the soil profile of the control and limed plots 2003-2015: (a) G1 sites and (b) G2 sites. \#-limed plots significantly different from control; * - significant differences between current and previous sampling campaign.

At the control plots there was a tendency for an increase of total $\mathrm{Ca}$ in the O-layer and exchangeable $\mathrm{Ca}^{2+}$ in the mineral soil (Figure 7), which was significant at G1 sites until $10 \mathrm{~cm}$ topsoil between 2010 and $2015\left(R_{\mathrm{r}} 0.8-5.6\right)$, and at $\mathrm{G} 2$ sites $0-5 \mathrm{~cm}$ between 2003 and $2010\left(\mathrm{RR}_{\mathrm{r}} 0.71\right)$.

The effect of lime treatment on forest floor total Ca-concentration is a significant increase in the first seven years after the second lime application $\left(R R_{r} 3.05-7.33\right)$, and a decrease (significant for $G 1$, $\left.R_{\mathrm{r}}-0.34\right)$, i.e., the reverse process between 2010 and 2015 across all study sites. Between 2003 and 2010 the mineral soils experienced a significant increase of exchangeable $\mathrm{Ca}$ in 0-30 cm, especially strong at G1 sites $\left(R_{\mathrm{r}} 5.72-18.61\right)$. Afterwards Ca concentrations increased significantly only in $0-10 \mathrm{~cm}$ at G1 $\left(R R_{\mathrm{r}}\right.$ 1.06-1.6), and just slightly at $\mathrm{G} 2$ sites.

Both organic layer total $\mathrm{Mg}$ and mineral soil exchangeable $\mathrm{Mg}^{2+}$ (see Appendix B) developed similarly to Ca. The difference was a significant recovery at G2 control plots in the O-layer $\mathrm{Mg}$ 2003-2015 $\left(R_{\mathrm{r}} 0.34\right.$ and 0.25$)$ without any significant improvement further down. Additionally, the liming effect significance reached down to $60 \mathrm{~cm}$ mineral soil in 2003-2010 at both G1 and G2 study sites.

There was little change in the concentrations of the other base cations $\mathrm{K}$ and $\mathrm{Na}$ (see Appendix $\mathrm{B}$ ). What is notable is the significant reduction of exchangeable $\mathrm{K}$ in $30-60 \mathrm{~cm}$ depth at G2 sites between 2010 and 2015 irrespective of treatment. 

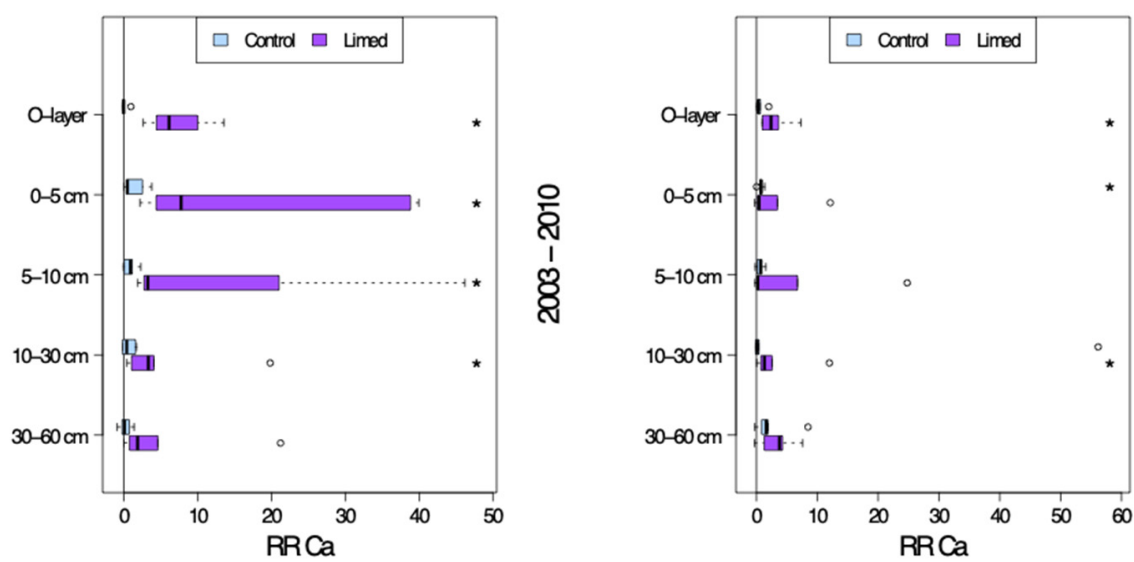

\section{을
1
ర్}
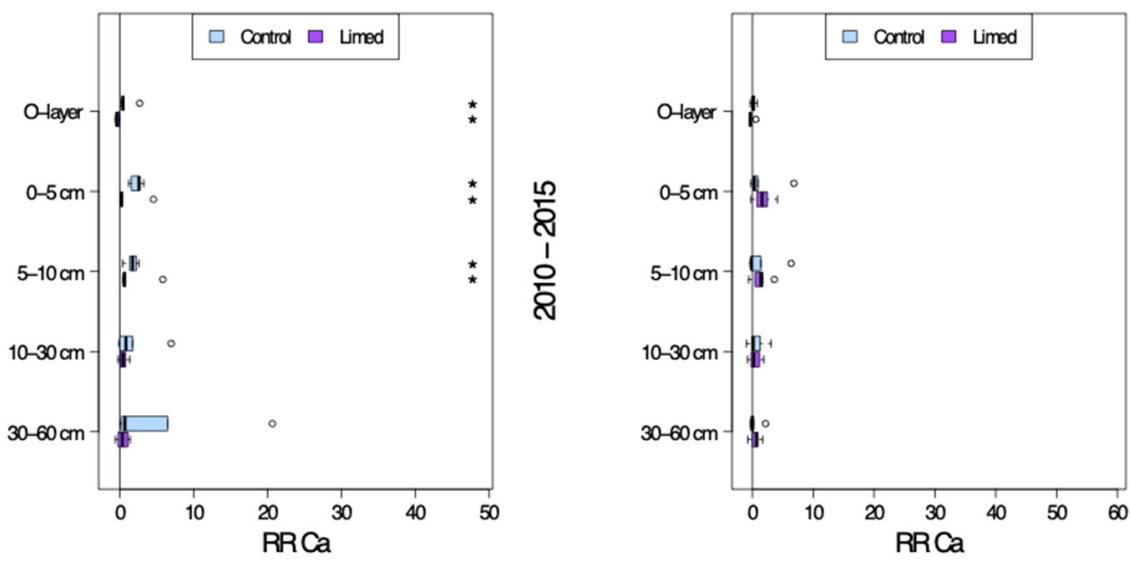

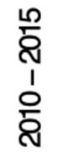

(a)

(b)

Figure 7. Calcium response ratio $\left(R R_{r}\right)$ in the soil profile seven years after (2003-2010) and twelve years after the second lime treatment (2010-2015): (a) G1 sites and (b) G2 sites. * - significant differences between current and previous sampling campaign.

It became obvious that $\mathrm{Al}$ was the strongly dominant exchangeable cation and remained so in the control plots throughout the entire sampling period 2003-2015. Forest floor total Al and mineral soil exchangeable $\mathrm{Al}$ concentrations (Figure 8) at the control plots showed no significant change over time $\left(G 1 R_{r}-0.09-1.33\right.$ and $\left.G 2 R_{r}-0.13-0.34\right)$; only the $G 2$ site O-layer Al was significantly higher in 2010 compared to $2003\left(R_{r} 0.22\right)$ and in $10-30 \mathrm{~cm}$ significantly lower $\left(R_{\mathrm{r}}-0.1\right)$.

In response to the second liming treatment in 2003 mineral topsoils' exchangeable $\mathrm{Al}$ followed a trend opposite to that of $\mathrm{Ca}$ and $\mathrm{Mg}$, and was distinctly reduced in $0-10 \mathrm{~cm}$ at both $\mathrm{G} 1$ and $\mathrm{G} 2$ sites between 2003 and 2010 at G1 and G2, though significantly only in $0-5 \mathrm{~cm}$ topsoil by $2010\left(\mathrm{G} 1 \mathrm{RR}_{\mathrm{r}}-0.67\right.$ and $\left.\mathrm{G} 2 \mathrm{RR}_{\mathrm{r}}-0.37\right)$.

Soil Fe concentrations (see Appendix B) were obviously present at all sites especially in the $0-10 \mathrm{~cm}$ mineral soils. Significant changes over time in the topsoil occurred at G2 sites only, where total Fe concentrations increased in the control plot O-layer $\left(R_{\mathrm{r}} 0.37\right)$ and exchangeable Fe decreased in the limed plot 0-5 cm $\left(R R_{r}-0.36\right)$ in the period 2003-2010. The subsoil Fe concentrations changed just with low absolute values, which however resulted in significant RR-values, whereby Fe-concentrations increased in 2003-2010 and slightly decreased in 2010-2015-more or less significantly at all study sites. 

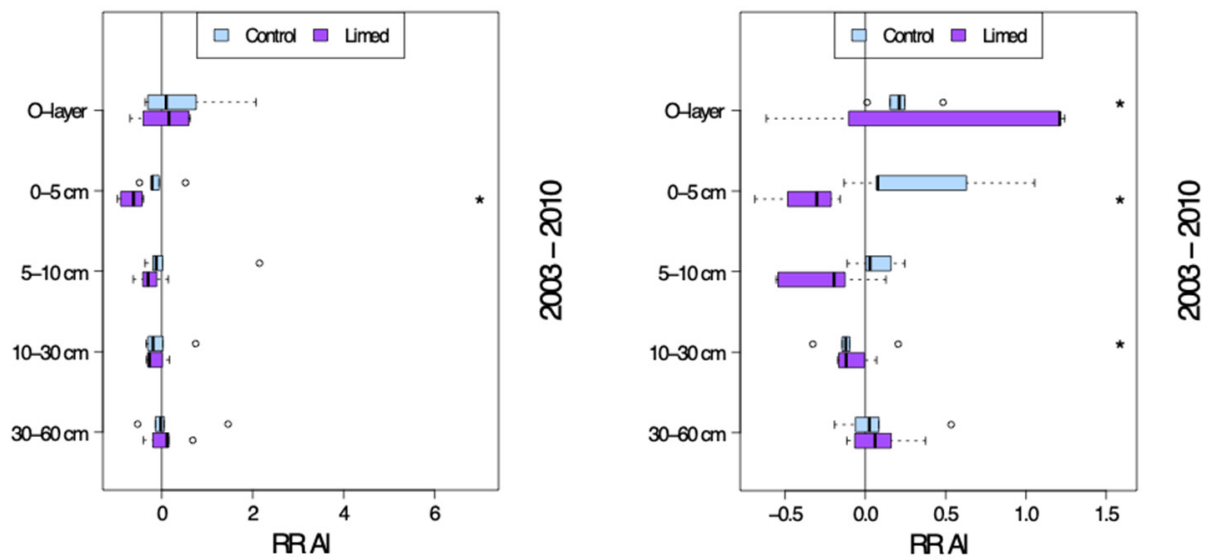

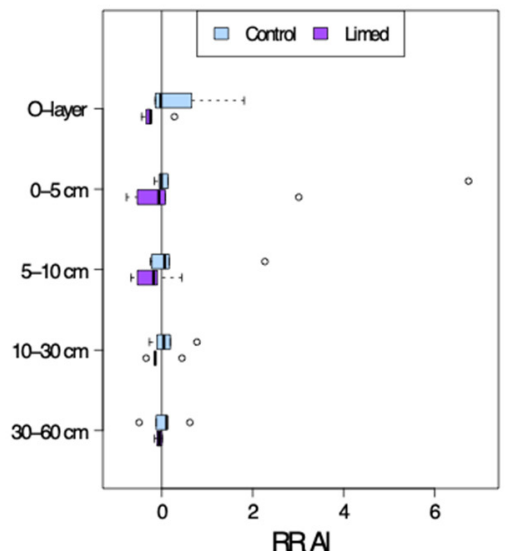

(a)

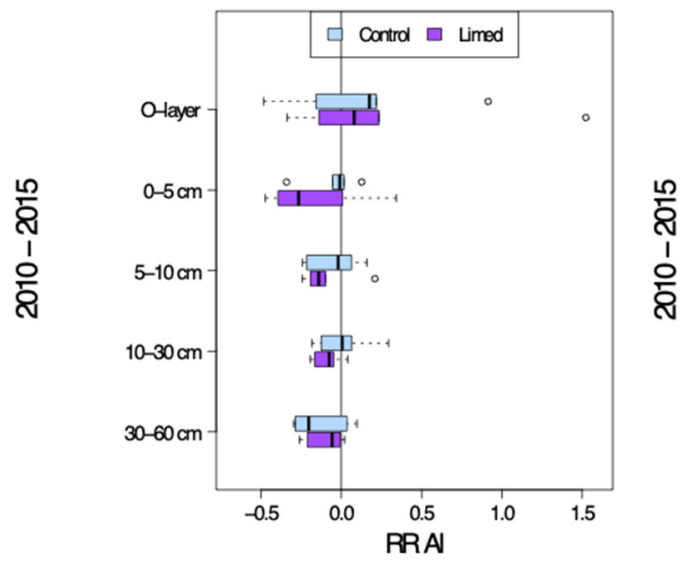

(b)

Figure 8. Aluminum site average response ratio $\left(R R_{r}\right)$ seven years after (2003-2010) and twelve years after the second lime treatment (2010-2015). (a) G1 study sites and (b) G2 study sites. * — significant differences between current and previous sampling campaign.

Across all study sites forest floor total Mn concentrations were significantly higher at limed plots relative to control 7 and 12 years since the last lime application; in addition after liming also the exchangeable $\mathrm{Mn}$ in 0-5 cm topsoil was significantly higher at G1 sites (see Appendix B).

Exchangeable protons $\mathrm{H}$ (also see Appendix B) were significantly lower at limed plots compared to control in 0-5 cm topsoil in 2010 for both G1 and G2, as well as in 0-10 cm (G1) and 0-5 cm (G2) in 2015.

\subsection{O-layer Stocks, Carbon and Nitrogen}

For the evaluation of changes in carbon concentrations, the humus layer stocks have to be considered, too (Figure 9). At both G1 and G2 study sites the O-layer stocks were (not significantly) lower at limed plots relative to control in 2003, and in 2010 they were comparable. In 2015 the limed plot O-layer stocks were significantly lower due to a tendency of increasing O-layer stocks at control plots (G1 RR 0.15 n.s. and G2 RR 0.32 n.s.) and a decrease at limed plots $\left(G 1 R_{r}-0.3\right.$ significant and G2 $R_{R}-0.25$ n.s.; Figure 10). In the mineral soil we assumed constant fine earth stocks, thus the changes of the concentrations could be compared directly. 

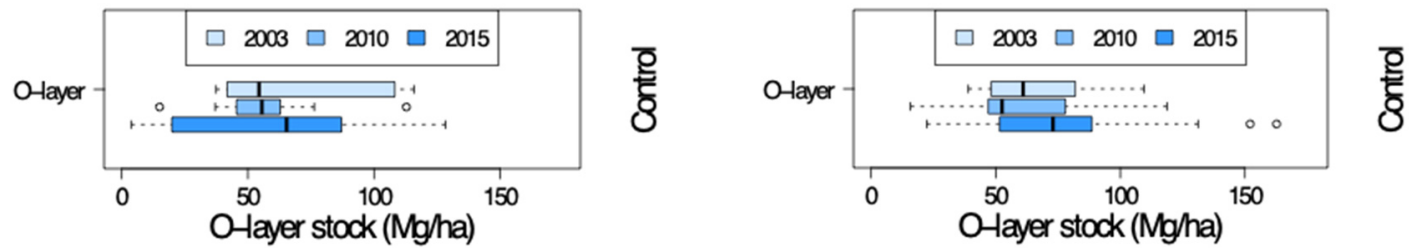

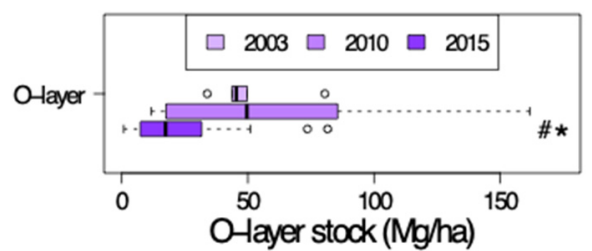

(a)

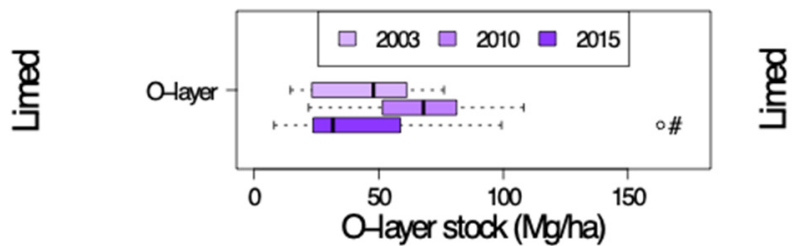

(b)

Figure 9. Organic layer stocks of control and lime treated plots in 2003-2015. (a) G1 study sites and (b) G2 study sites. \#-limed plots significantly different from control; ${ }^{*}$ - significant differences between current and previous sampling campaign.
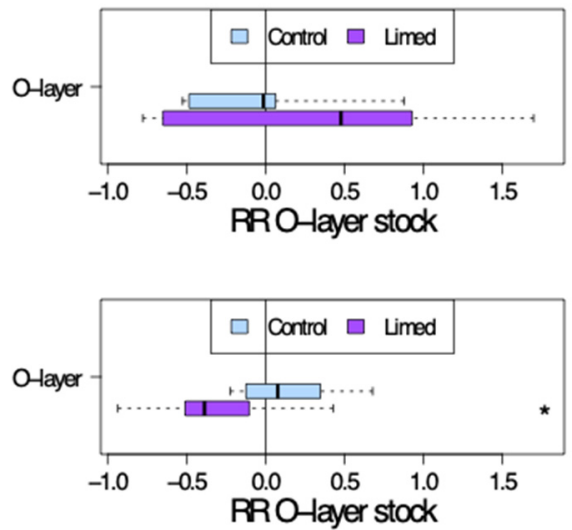

(a)

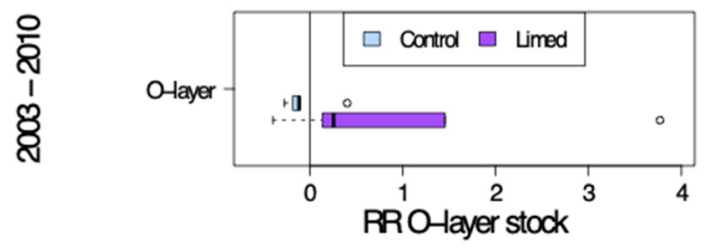

을
1
8
8
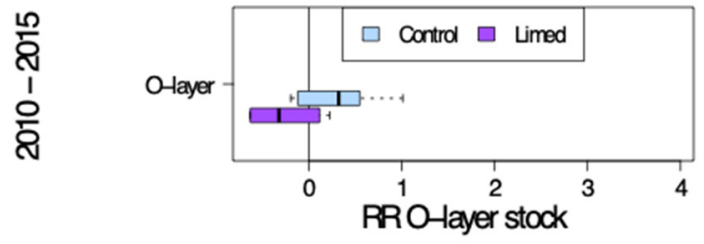

10
ำ
1
을

Figure 10. Organic layer stock site average response ratio $\left(R R_{r}\right)$ seven years after (2003-2010) and twelve years after the second lime treatment (2010-2015). (a) G1 study sites and (b) G2 study sites. *-significant differences between current and previous sampling campaign.

The control plots show little significant change in carbon concentrations between 2003 and 2015 (see Appendix B). Only the G1 site O-layer $C_{\text {tot }}$ significantly decreased in 2010-2015 $\left(R_{\mathrm{r}}-0.12\right)$.

Between 2003 and 2010 this $C_{\text {tot }}$ was significantly decreasing, however, and was again comparable to that of the control. At G1 sites $C_{\text {tot }}$ remained comparable between the control and limed, except for the significantly lower O-layer $C_{\text {tot }}$ in 2010. In 0-10 cm topsoil of limed $\mathrm{G} 1$ sites $\mathrm{C}_{\text {tot }}$ concentrations rose significantly in the period 2003-2010 $\left(\mathrm{RR}_{\mathrm{r}} 0.28-0.61\right)$.

At the control plots, the total nitrogen in the soil profile of G1 sites (see Appendix B) remained on average unchanged since 2003, with a tendency to increase in the entire measured mineral soil profile. Similarly at G2 sites, except for significantly increased $N_{\text {tot }}$ in 0-5 cm between 2010 and $2015\left(R_{\mathrm{r}} 0.34\right)$.

At limed plots the only significant rise in $\mathrm{N}_{\text {tot }}$ concentrations occurred in $0-5 \mathrm{~cm}$ topsoil. At G1 the RR was 0.65 between 2003 and 2010, leading to significantly higher $\mathrm{N}_{\text {tot }}$ between limed and control plots in 2010. G2 site $N_{\text {tot }}$ concentrations significantly dropped $\left(R R_{r}-0.32\right)$, only to once again increase in 2010-2015 ( $R_{\mathrm{r}}$ 0.32; overall similar development to $\left.C_{\text {tot }}\right)$. 
While at $\mathrm{G} 2$ sites the $\mathrm{C} / \mathrm{N}$ ratio remained comparable between the sampling periods 2003-2015 and between both control and limed plots, at G1 sites C/N significantly increased in the limed plot O-layer between 2010 and 2015, so that lime treated site C/N was 27, and control C/N was 24 in 2015. Meanwhile, in $0-5 \mathrm{~cm}$ mineral soil limed plot $\mathrm{C} / \mathrm{N}$ decreased (n.s.) and limed plot $\mathrm{C} / \mathrm{N}$ of 19 was significantly lower than the control plot $\mathrm{C} / \mathrm{N}$ of 21 .

\section{Discussion}

After a short discussion on methodological characteristics and boundary conditions of our study, we will discuss the temporal development of soil chemistry at the control plots, which will allow us to evaluate the extent of natural recovery. Afterwards we will assess the effects of lime treatment as the intended counter-measure to soil acidification. We differentiated our study sites by their soil chemical and physical properties to identify those site parameters, which affect both the rate of natural recovery and response to liming.

\subsection{Discussion on Methods and Boundary Conditions of the Study}

The soil sampling in the campaigns of 2003 and 2010 were focused upon element concentrations being analyzed at disturbed bulk samples, which did not allow for calculation of element stocks. Only in the last campaign 2015 volumetric soil samples were taken allowing for determination of bulk density of fine earth and volumetric content of the coarse soil fraction. However, also the volumetric reference is somehow unsharp because the samples were taken with an auger and artificial compaction of the soil samples cannot be excluded. Due to that uncertainty and above all because of comparability among the results of the sampling campaigns we decided to perform all evaluations on the basis of element concentrations.

The dosage of the lime application between the liming campaigns in 1983/84 and 2003 were different- the latter was with $6 \mathrm{Mg} \mathrm{ha}^{-1}$ roughly double the dosage of the first campaign. Vice versa were the "reaction times" of both liming campaigns. The effect of the first campaign was observed in 2003, 20 years after liming. Between 1983 and 2003 the highest acid load from deposition in Central Europe occurred [30]. Therefore it is probable that a high proportion of the buffer capacity from the first campaign was neutralized by deposition before 2003. Both observation periods 2003-2010 and 2010-2015, with a length of 7 and 5 years, were more or less comparable, but much shorter than 20 years. The fact that this study is based on data from three sampling campaigns provides some insight in the dynamics of both the natural recovery as well as the lime treatment effects, which can be derived predominantly from the RR plots. However, the assessment of the exact temporal dynamics of the liming effects are incriminated with uncertainty and may only been derived as tendencies.

\subsection{Natural Recovery of Acidified Soils}

A natural recovery of soil $\mathrm{pH}$ that we found was overall slight, and comparable in both $\mathrm{H}_{2} \mathrm{O}$ and $\mathrm{KCl}$ throughout the entire soil profile. Between 2003 and $2015 \mathrm{pH}-\mathrm{H}_{2} \mathrm{O}$ rose by $0.6-0.7 \mathrm{pH}$ units in the organic horizon and by $0.2-0.3 \mathrm{pH}$ units in mineral soil. In the O-layer and $0-10 \mathrm{~cm}$ topsoil the $\mathrm{pH}-\mathrm{H}_{2} \mathrm{O}$ remained $\leq 4.2$ and $\mathrm{pH}-\mathrm{KCl} \leq 3.5$, i.e., extremely acidic until 2015. The average $\mathrm{pH}-\mathrm{KCl}$ of 3.0 in the mineral topsoil samples of our study sites in the 1980s [23] (pp. 36-37) thus has seen little improvement over three decades. In the comparison between Germany's 1st and 2nd National Forest Soil Inventory (NFSI) at acidification-sensitive unlimed sites Meesenburg et al. [12] (p. 100) found $\mathrm{pH}-\mathrm{H}_{2} \mathrm{O}$ had increased in the O-layer and 0-10 cm mineral soil from 1987-1992 until 2006-2008, although without a significant change in $\mathrm{pH}-\mathrm{KCl}$. An effect of increasing $\mathrm{pH}$ values in the subsoil, which we found in our study, has not yet been reported (to our knowledge) as a consequence of reduced acid deposition. While at $\mathrm{G} 1$ sites - which had overall lower $\mathrm{pH}-\mathrm{KCl}$, lower $\mathrm{CEC}$ and higher exchangeable Al stocks in the topsoil, as well as predominantly coarser soil-fractions-a distinct recovery was already seen from 2003 until $60 \mathrm{~cm}$ in the soil profile, at G2 sites the natural recovery was significant only to the depth of $30 \mathrm{~cm}$ mineral soil. 
After 2003 only slight changes in the mineral soil base saturation could be observed at the control plots, which for the most part remained at $<20 \%$ BS. The comparison between NFSI I and II found prevailing low topsoil base saturation in almost every region in Germany and loss of BS in 5-90 cm soil profiles of unlimed acid-sensitive soils, noting that the base cation uptake as tree nutrients as well as remobilization of $S$ and nitrification processes may have contributed to this trend [12] (p. 102). In our study we found the base cations $\mathrm{Ca}$ and $\mathrm{Mg}$ tended towards natural recovery, which was however only significant in the O-layer (Mg) or in topsoil (Ca). No improvement was found for K concentrations, which irrespective of treatment even declined in the 30-60 cm subsoil between 2010 and 2015. All-in-all, despite the slight recovery we observed at our study sites, $\mathrm{pH}$ values and base saturation are still far from pre-industrial values, which are reported or modeled to have been distinctly higher [9].

Since the control plot $\mathrm{pH}-\mathrm{H}_{2} \mathrm{O}$ of $\leq 4.2$ in the topsoil is still predominantly in the $\mathrm{Al}$ and $\mathrm{Al}-\mathrm{Fe}$ buffer range [12] (p. 95), which Wilpert et al. [23] (pp. 37-38) found already in our 1980s samples, and the base saturation remained low, the lack of reduction in the acid cation $\mathrm{Al}$ and $\mathrm{Fe}$ concentrations that we found is not surprising. Thus there has been little change in control plot CEC and the exchangeable cation concentrations over time.

While in Wilpert et al. [23] (pp. 31-34) increased O-layer thickness at the control plots from 1985/86 to 1989/90 was reported, from 2003 on neither O-layer stocks or $C_{\text {tot }}$ and $N_{\text {tot }}$ concentrations changed significantly at our control plots, except for a significant decrease in the O-layer $C_{\text {tot }}$ at $\mathrm{G} 1$ and a significant increase of $0-5 \mathrm{~cm}$ topsoil $\mathrm{N}_{\text {tot }}$ at G2 between 2010 and 2015. There was no noticeable change in the $\mathrm{C} / \mathrm{N}$ ratio.

\subsection{Effects of Liming}

The depth gradient of liming was obvious, whereby a downward movement of lime treatment effects in the soil profile over time occurred. A simplified interpretation of the RR-values gives the impression that the liming effects are very strong in the first period and hardly significant in the second period and thus have lessened substantially. However, this could also mean that the strong effects of liming in the first observation period are still ongoing, but with no further strong amplification. Dolomite limestone has principally low solubility, which is likely an important factor in our study. The solution rate of limestone is controlled by the factors humidity, $\mathrm{CO}_{2}$ partial pressure and $\mathrm{pH}$ value [31] (pp. 195-197). Humidity and $\mathrm{CO}_{2}$ partial pressure are on the mid-term constant factors and thus limiting the solution rate constantly. Low $\mathrm{pH}$ values on heavily acidified soils accelerate the dissolution rate. As we found distinctly increased $\mathrm{pH}$ values as a direct effect of liming, in the reverse one can conclude that this $\mathrm{pH}$ increase should decelerate the further dissolution rate. Thus we cannot assume whether the liming effects of the second, high-dosed liming campaign have weakened essentially or dissolution rates are reduced and thus the liming effects have not yet developed fully in the last observation period 2010-2015.

$\mathrm{Li}$ et al. [16] identified increased liming rate as the main driver in soil $\mathrm{pH}$ improvements, which might explain why the first lime application of $3 \mathrm{t} \mathrm{ha}^{-1}$ in 1980s no longer had a significant effect compared to control plot $\mathrm{pH}$ by 2003. Wilpert et al. [23] (pp. 36-38) saw the liming effect on topsoil $\mathrm{pH}$ decline already 5-6 years after treatment, with an increase of just $0.2 \mathrm{pH}$ units then compared to $0.9 \mathrm{pH}$ units 1-2 years after. The second lime dose of $6 \mathrm{tha}^{-1}$ made a notable difference both 7 and 12 years after application. Similar to the findings of Pabian et al. [32], Court et al. [13] and Meesenburg et al. [12] (p. 100), our study showed that liming greatly accelerated the rise in soil $\mathrm{pH}-\mathrm{H}_{2} \mathrm{O}$ compared to control plots by $0.6-2.2$ units down to $10 \mathrm{~cm}$ topsoil and a decreasing (yet still significant) effect with depth in the entire measured soil profile during the first 7 years since 2003 treatment. In the following years-between 2010 and 2015-the limed plot forest floor $\mathrm{pH}$ was again decreasing, though the positive difference to control remained significant. Drápelová et al. [10] also found reacidification of limed Ol-horizon 12 years after treatment while the deeper horizons did still show decreased acidity compared to the control. 
The effect of liming appears to have reached greater depth-up to $60 \mathrm{~cm}-$ in the soil profiles of G1 sites in less time compared to G2 where below $30 \mathrm{~cm}$ mineral soil the limed treatment was no longer significantly different from the control in the first 7 years since last lime treatment. In the 7-12 year period the $\mathrm{pH}$ change at both G1 and G2 plots was lower and comparable to natural regeneration (although limed plot $\mathrm{pH}$ still remained significantly higher than the control). Li et al. [16] saw the maximum effect of lime in the first 3 years after application, although the different environmental and ecological conditions potentially delay or reduce liming effects. Their study found that lower initial soil $\mathrm{pH}$ led to stronger liming effects as well as increased variances. Reid and Watmough [17] also showed that initially extremely acidic sites treated with high doses showed the highest increase in $\mathrm{pH}$. In our case, from 2003 on the soil $\mathrm{pH}-\mathrm{H}_{2} \mathrm{O}$ values were comparable at $\mathrm{G} 1$ and $\mathrm{G} 2$ sites while $\mathrm{pH}-\mathrm{KCl}$ was lower at G1, indicating that perhaps the soil texture differences (a higher sand fraction in G1 soil profiles) had impact on the site-specific development in soil $\mathrm{pH}-\mathrm{KCl}$.

The temporal change in soil $\mathrm{pH}-\mathrm{KCl}$ due to lime application was similar in the O-layer and 0-10 cm (G1) and 0-5 cm (G2) topsoil, while further down in the soil profiles no significant liming effect was observed. Huber et al. [33] found similar results. While $\mathrm{pH}-\mathrm{H}_{2} \mathrm{O}$ is a measure of the effective soil acidity and shows seasonal fluctuations, $\mathrm{pH}-\mathrm{KCl}$ takes into account also the potential acidity of released exchangeable $\mathrm{Al}$ and $\mathrm{H}$ in soil and therefore is a long-term measure of soil $\mathrm{pH}$ [12] (p. 97). Indeed we found no significant reduction in exchangeable $\mathrm{Al}$ or proton concentrations below $10 \mathrm{~cm}$ depth at our limed plots, which indicates that the subsoil of limed plots has not yet fully recovered from acidification.

The total $\mathrm{Al}$ and Fe concentrations were significantly higher in the O-layer of G1 limed plots in 2003, i.e., 20 years after the 1st lime treatment in the 1980s. We presumed this resulted from bioturbation and subsequent mixing of mineral soil with the organic soil material; notably lower $C_{\text {tot }}$ concentrations in the limed plot O-layer support this assumption. The 2nd lime treatment in 2003 obviously limited — and even reversed - the extent to which $\mathrm{Al}, \mathrm{Fe}$ and $\mathrm{H}$ cations were increasing at our study sites in the upper $0-10 \mathrm{~cm}$ soil profile by 2015 , compared to the control. A difference that Meesenburg et al. [12] (pp. 99-100) found between NFSI I and II was a reduction in Al and Al-Fe buffer range and an increase in the exchange buffer and even silicate buffer ranges at limed plots in 0-30 cm mineral soil.

The 1st lime application in the 1980s improved topsoil base saturation at our study sites by $17 \%$ after 5 years [23] (p. 43). While by 2003 there was no significant difference between the limed and control plot BS any more (except for still significantly higher exchangeable $\mathrm{Ca}$ in $0-5 \mathrm{~cm}$ topsoil), afterwards the 2nd lime treatment again made a significant impact improving base saturation in the entire $0-60 \mathrm{~cm}$ mineral soil profile of all study sites-by $40-70 \%$ in the organic layer and by $7-50 \%$ in mineral soil. Specifically, the concentrations of base cations $\mathrm{Ca}$ and $\mathrm{Mg}$-the main constituents of dolomite lime-rose significantly until $30 \mathrm{~cm}$ and $60 \mathrm{~cm}$ mineral soil respectively in the first 7 years after last lime treatment. Meanwhile, neither Wilpert et al. [23] (pp. 44-45) nor we observed a distinct liming effect on $\mathrm{K}$ concentrations, similar to findings of Huber et al. [33]. Court et al. [13] found a BS of $9 \%$ at the control and $41 \%$ at the limed plots 16 years after treatment and significantly increased exchangeable $\mathrm{Ca}, \mathrm{Mg}$ and $\mathrm{K}$ in $0-15 \mathrm{~cm}$ topsoil. Guckland et al. [34] also found a significantly increased BS in $0-40 \mathrm{~cm}$ mineral soil 28 years after lime application, with a mean increase of $11 \%$. Meesenburg et al. [12] (pp. 102, 110) showed an increase in 0-30 cm mineral soil BS between NFSI I and II at limed sites, especially on largely base-depleted plots.

Our study found the limed plot BS response ratio was double in the soil profile of G1 sites compared to G2 sites in 2003-2010 period, despite the Ca concentrations being significantly higher in the $0-5 \mathrm{~cm}$ topsoil of G2 limed sites compared to control in 2003 already (after the 1st lime application in 1980s). After 2010, i.e., 7-12 years since 2nd liming in both site groups the $\mathrm{RR}_{\mathrm{a}}$ of $\mathrm{BS}$ was declining, however. This is in agreement with findings of several studies that liming effects reached their maximum in the first decade after treatment [13,35], and Reid and Watmough [17] who showed that time since treatment has a major influence on BS response to liming. Reid and Watmough [17] noted 
that also soil type as well as the tree species would have an impact on the intensity and dynamic of liming effects. At our study sites we could not differentiate a stand effect as both groups contain a mixture of stand types with varying dominance of Norway spruce. The effect of soil types could also not be proven as they were from similar classes in our study, however, the texture seems to play a distinct role in differentiating G1 and G2 study site liming effect on BS. This effect was also shown by Li et al. [16] who found 32\% higher liming effects in sandy soils than clayey soils. His argument was that fine textured soils show a greater buffering capacity to changes in soil chemical properties than coarse-textured soils.

While at G1 sites limed plot CEC significantly increased compared to the control in the $0-5 \mathrm{~cm}$ topsoil, where as discussed the increase in $\mathrm{BS}$ as well as the decrease in $\mathrm{Al}$ and $\mathrm{Fe}$ was of greater magnitude, at G2 sites a significant rise in CEC was found in 10-60 cm subsoil, where especially in 30-60 cm the exchangeable $\mathrm{Ca}$ and $\mathrm{Mg}$ limed plot $R R_{\mathrm{r}}$ still exceeded natural regeneration $R_{\mathrm{r}}$ by 2015 . Guckland et al. [34] reported similarly increased CEC after liming due to increased exchangeable Ca and $\mathrm{Mg}$ replacing exchangeable acidity and/or $\mathrm{Al}^{3+}$ in the upper mineral soil, meanwhile without effect on CEC in the 20-40 cm mineral soil. These different reactions on liming at G1 and G2 sites indicate different processes triggered on these site groups by lime application. These processes could be on the one hand replacement of $\mathrm{Al}^{3+}$ with $\mathrm{Ca}^{2+}$ and $\mathrm{Mg}^{2+}$ as the statement of Guckland et al. [34] suggests. This process reduces the activity of $\mathrm{Al}$-ions in the soil solution, which generates protons through hydrolysis [31] (pp. 190-191). On the other hand the high increase of $\mathrm{pH}-\mathrm{H}_{2} \mathrm{O}$ throughout the soil profile down to $30-60 \mathrm{~cm}$ and the partially increased CEC suggest that according to the theory of variable charges of exchanger surfaces in the soil [31] (pp. 170-173), the amount of negative charges und thus $\mathrm{CEC}$ increases with increasing $\mathrm{pH}$. The process behind that is an increase in $\mathrm{pH}-\mathrm{H}_{2} \mathrm{O}$ functional groups of metal hydroxides $(\mathrm{OH})$, of alumo-silicates $(\mathrm{SiOH}, \mathrm{AlOH})$ and of carboxyl groups $(\mathrm{COOH})$ that get de-protonized and thus increase the negative charge of the exchanger surfaces as well as CEC. The third process that could explain changes of CEC is a translocation of carbon from the O-layer to the mineral soil. This can generate new organic exchanger surfaces [31] (p. 175). The significant increase of CEC at G1 sites in $0-5 \mathrm{~cm}$ was accompanied by a significant and over-proportionally strong increase of $\mathrm{pH}-\mathrm{H}_{2} \mathrm{O}$ and indeed a significant increase of $\mathrm{C}_{\text {tot }}$. This suggests that in the more sandy soils of G1 sites the increase of organic carbon in combination with increased $\mathrm{pH}$ might have created new exchanger places and thus were the dominating process explaining increasing CEC there. The described processes might also have occurred in 5-10 cm, where similar changes were observed, which however were not as strong and overall not significant.

At G2 sites with more loamy texture and higher colloid content and higher CEC at control plots a weak, but significant increase of CEC occurred after liming in mineral soil layers below $10 \mathrm{~cm}$. The only predictor that shows at G2 sites a substantially higher reaction on liming in that depth layers is base saturation. This is due to a higher amount of $\mathrm{Al}$ being mobilized from the exchanger surfaces and replaced by $\mathrm{Ca}$ and $\mathrm{Mg}$. This depletion of $\mathrm{Al}$ is visible in Figure 8 to the depth of $30 \mathrm{~cm}$. At the depth layer 30-60 cm Figure 8 shows no depletion of $\mathrm{Al}$ rather than a possible increase indicating partial resorption of $\mathrm{Al}$ mobilized in the upper soil layers. It is somehow an unexpected finding that at the more loamy G2 sites the liming effect on CEC reaches deeper than at G1 sites where a higher water permeability could be expected according to the more sandy texture. The explanation might be the higher natural sorption capacity of G2 sites and perhaps preferential flow paths enhancing the "short-cut" like transport of Ca- and Mg-ions to deeper soil layers.

We also found few distinct effects of liming on carbon and nitrogen properties of the studied sites, which allow a further ecological discussion. The limed plot O-layer stocks were comparable to those of the control in the 2003-2010 period. Afterwards in 2010-2015 they were significantly lower-similar to what Wilpert et al. [23] (pp. 31-34) observed 1 and 5 years after the 1980s lime treatment at our study sites. Court et al. [13] also found decreasing O-layer dry weight mid to long term after liming, likely due to enhanced microbial activity and accelerated decomposition rates. Meanwhile $C_{\text {tot }}$ decreased in the O-layer, and increased in the $0-10 \mathrm{~cm}$ topsoil of G1 sites in the first 7 years after 2 nd lime 
application. Additionally, $\mathrm{N}_{\text {tot }}$ concentrations rose in the $0-5 \mathrm{~cm}$ topsoil after liming. Kreutzer (1995) showed changed O-layer morphology with increased mineral content in the O-layer and organic matter transported downward as a result of earthworm activity at limed plots-probably this also occurred at our G1 study sites.

At $\mathrm{G} 2$ sites $0-5 \mathrm{~cm} \mathrm{C} \mathrm{C}_{\text {tot }}$ and $\mathrm{N}_{\text {tot }}$ were significantly higher at limed plots in 2003, potentially a persisting effect of the 1st lime treatment in 1980s, where by the end of the 1980s increased variance of the limed plot C-content in the topsoil was observed [23] (pp. 34-35). After 2003, though, both control and limed treatment $\mathrm{C}_{\text {tot }}$ and $\mathrm{N}_{\text {tot }}$ concentrations were comparable. Ouimet and Moore [20] also observed no significant change in forest floor $\mathrm{C}_{\text {tot }}$ and $\mathrm{N}_{\text {tot }}$ concentrations after lime treatment, indicating no obvious change in mineralization rates.

Despite G1 limed plot $\mathrm{C} / \mathrm{N}$ significantly increasing in the O-layer and significantly decreasing in $0-5 \mathrm{~cm}$ mineral topsoil between 2010 and 2015, C/N ratio remained in the range typically under Norway spruce in cambisols, podsols and stagnosols according to Cools et al. [36].

\section{Conclusions}

Lime treatment has had notable positive effects on our soil's recovery that are visible in the entire studied soil profile. Thus in soils with proven soil acidification-where it exceeds natural acidification-we recommend liming to be established as a long-term forestry management practice. Site characteristics like soil texture and acidity status have to be taken into account when considering the site-specific outcomes of both natural and aided soil recovery.

In order to evaluate even further the mechanisms of soil development in the process of recovery from acidification over time it would be beneficial to expand the research at our study sites in the future. Further measured ecosystem parameters could be evaluated, e.g., possible changes in soil physics and water budget that impact our soil's hydrological functions, as well as the biological activity of soil fauna, plant root distributions and nutrients in plant biomass as important indicators of overall recovery and stabilization of biodiversity and ecosystem functionality.

Supplementary Materials: The following are available online at http://www.mdpi.com/2571-8789/4/3/38/s1, Table S1: Original data: O-layer chemistry 2003-2015, Table S2: Original data: Mineral soil chemistry 2003-2015, Table S3: Original data: Mineral soil chemistry 2015 with stock calculations, Table S4: G1 study site historic development in 2003-2015 (full version), Table S5: G2 study site historic development in 2003-2015 (full version), Table S6: G1 study site parameter response ratios (RR) to time in 2003-2015 (full version), Table S7: G2 study site parameter response ratios (RR) to time in 2003-2015 (full version).

Author Contributions: Conceptualization, P.H. and K.v.W.; Data curation, L.J., P.H. and K.v.W.; Formal analysis, L.J. and P.H.; Funding acquisition, K.v.W.; Investigation, L.J., P.H. and K.v.W.; Methodology, P.H. and K.v.W.; Project administration, P.H. and K.v.W.; Software, L.J.; Supervision, P.H. and K.v.W.; Validation, P.H.; Visualization, L.J.; Writing—original draft, L.J.; Writing—review and editing, L.J., P.H. and K.v.W. All authors have read and agreed to the published version of the manuscript.

Funding: This research was funded by Bundesministerium für Ernährung und Landwirtschaft (BMEL), grant number 22028914 (2015-2017) and grant number 28W-B-4-075-02 (2018-2021).

Acknowledgments: We would like to thank our predecessors who have set up and managed our long-term research sites, and those many colleagues who have assisted in the field campaigns, in sample preparation, laboratory analysis and lent advice and moral support throughout the many hours of data analysis.

Conflicts of Interest: The authors declare no conflict of interest. The funders had no role in the design of the study; in the collection, analyses, or interpretation of data; in the writing of the manuscript, or in the decision to publish the results. 


\section{Appendix A}

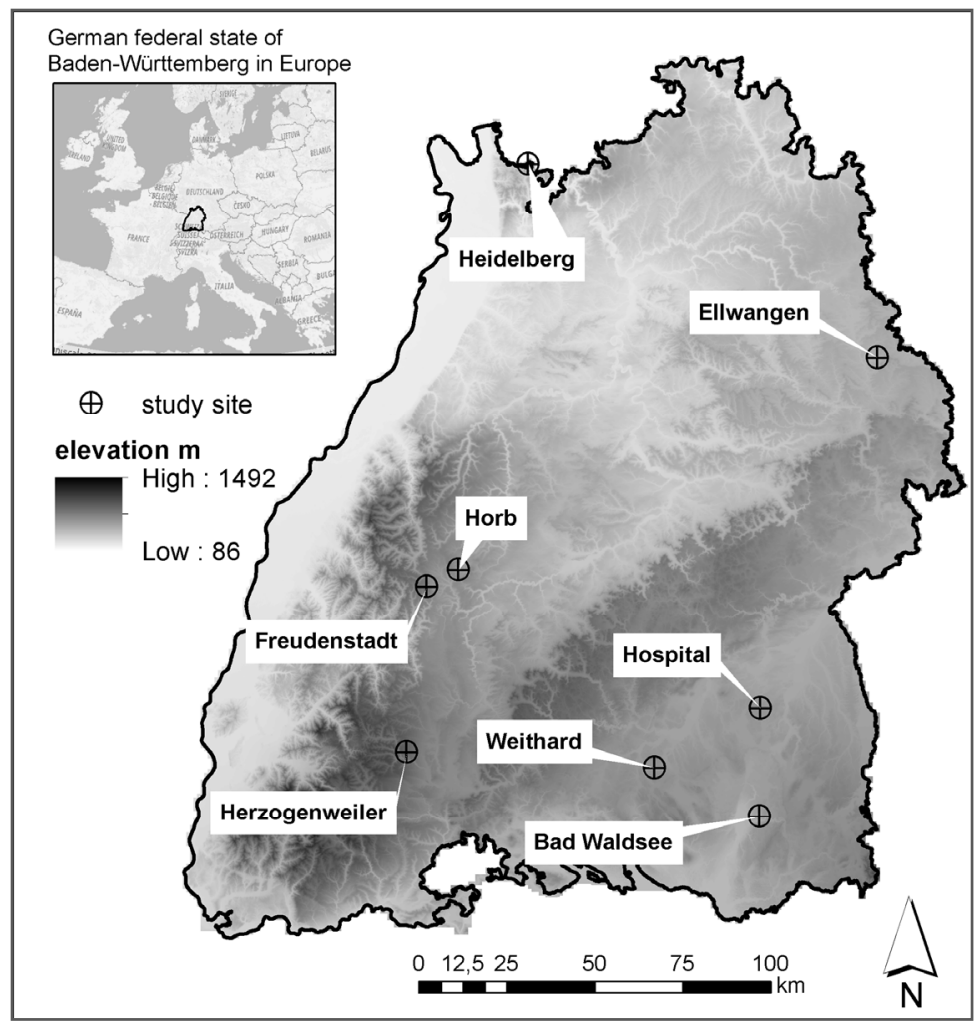

Figure A1. Study site location.

\section{Appendix B}

Table A1. G1 study site historic development of $\mathrm{pH}-\mathrm{KCl}, \mathrm{Mg}, \mathrm{K}, \mathrm{Na}, \mathrm{Fe}, \mathrm{Mn}, \mathrm{H}, \mathrm{C}$ and $\mathrm{N}$ in 2003-2015; given are group means with standard deviations. Marked bold—significant differences between current and previous sampling campaign, underline-limed plots significantly different from control.

\begin{tabular}{ccccccc}
\hline Parameter & Unit & Depth & Treatment & $\mathbf{2 0 0 3}$ & $\mathbf{2 0 1 0}$ & $\mathbf{2 0 1 5}$ \\
\hline $\mathrm{C} / \mathrm{N}$ & & O-layer & Control & $26.48(1.48)$ & $24.6(2.63)$ & $24.41(3.42)$ \\
$\mathrm{C} / \mathrm{N}$ & & O-layer & Limed & $23.98(2.36)$ & $24.27(1.8)$ & $\mathbf{2 7 . 1 6 ( 4 . 7 4 )}$ \\
$\mathrm{C} / \mathrm{N}$ & & $0-5 \mathrm{~cm}$ & Control & $20.74(3.48)$ & $20.96(2.19)$ & $21.41(5.71)$ \\
$\mathrm{C} / \mathrm{N}$ & & $0-5 \mathrm{~cm}$ & Limed & $20.68(3.5)$ & $20.09(3.12)$ & $18.72(1.92)$ \\
$\mathrm{C} / \mathrm{N}$ & & $5-10 \mathrm{~cm}$ & Control & $21.52(2.17)$ & $21.44(3.57)$ & $21.43(4.72)$ \\
$\mathrm{C} / \mathrm{N}$ & & $5-10 \mathrm{~cm}$ & Limed & $18.82(3.57)$ & $20.41(2.8)$ & $19.46(2.75)$ \\
$\mathrm{C} / \mathrm{N}$ & & $10-30 \mathrm{~cm}$ & Control & $20.64(4.57)$ & $18.14(2.48)$ & $18.53(4.29)$ \\
$\mathrm{C} / \mathrm{N}$ & & $10-30 \mathrm{~cm}$ & Limed & $17.28(2.21)$ & $18.93(2.97)$ & $17.99(2.78)$ \\
$\mathrm{C} / \mathrm{N}$ & & $30-60 \mathrm{~cm}$ & Control & $17.82(7.28)$ & $13.52(2.99)$ & $13.45(5.73)$ \\
$\mathrm{C} / \mathrm{N}$ & & $30-60 \mathrm{~cm}$ & Limed & $12.92(2.61)$ & $15.33(3.9)$ & $13.64(3.96)$ \\
$\mathrm{C}_{\text {tot }}$ & $\mathrm{g} / \mathrm{kg}$ & O-layer & Control & $403.64(81.13)$ & $385.75(44.88)$ & $338.14(66.53)$ \\
$\mathrm{C}_{\text {tot }}$ & $\mathrm{g} / \mathrm{kg}$ & O-layer & Limed & $286(104.16)$ & $301.56(81.34)$ & $322.93(60.94)$ \\
$\mathrm{C}_{\text {tot }}$ & $\mathrm{g} / \mathrm{kg}$ & $0-5 \mathrm{~cm}$ & Control & $42.43(29.47)$ & $45.62(25.02)$ & $52.17(28.84)$ \\
$\mathrm{C}_{\text {tot }}$ & $\mathrm{g} / \mathrm{kg}$ & $0-5 \mathrm{~cm}$ & Limed & $37.9(15.32)$ & $\mathbf{5 6 . 1 2 ( 2 2 . 7 7 )}$ & $61.19(27.55)$ \\
$\mathrm{C}_{\text {tot }}$ & $\mathrm{g} / \mathrm{kg}$ & $5-10 \mathrm{~cm}$ & Control & $23.63(14.14)$ & $24.12(10.85)$ & $27.01(13.14)$ \\
$\mathrm{C}_{\text {tot }}$ & $\mathrm{g} / \mathrm{kg}$ & $5-10 \mathrm{~cm}$ & Limed & $22.08(11.14)$ & $\mathbf{2 6 . 7 6 ( 1 0 . 4 6 )}$ & $32.01(13.08)$ \\
$\mathrm{C}_{\text {tot }}$ & $\mathrm{g} / \mathrm{kg}$ & $10-30 \mathrm{~cm}$ & Control & $12.49(8.29)$ & $12.94(6.04)$ & $13.14(8.1)$ \\
$\mathrm{C}_{\text {tot }}$ & $\mathrm{g} / \mathrm{kg}$ & $10-30 \mathrm{~cm}$ & Limed & $14.37(7.54)$ & $14.91(6.23)$ & $15.65(6.68)$ \\
\hline
\end{tabular}


Table A1. Cont.

\begin{tabular}{|c|c|c|c|c|c|c|}
\hline Parameter & Unit & Depth & Treatment & 2003 & 2010 & 2015 \\
\hline$C_{\text {tot }}$ & $\mathrm{g} / \mathrm{kg}$ & $30-60 \mathrm{~cm}$ & Control & $5.52(4.19)$ & $6.19(3.98)$ & $5.94(3.85)$ \\
\hline $\mathrm{C}_{\text {tot }}$ & $\mathrm{g} / \mathrm{kg}$ & $30-60 \mathrm{~cm}$ & Limed & $6.58(4.64)$ & $7.45(4.48)$ & $7.3(5.03)$ \\
\hline $\mathrm{Fe}$ & $\mathrm{g} / \mathrm{kg}$ & O-layer & Control & $2.52(0.95)$ & $3.5(1.5)$ & $4.31(2.06)$ \\
\hline $\mathrm{Fe}$ & $\mathrm{g} / \mathrm{kg}$ & O-layer & Limed & $5.54(1.92)$ & $5.67(2.58)$ & $4.08(2.01)$ \\
\hline $\mathrm{Fe}^{3+}$ & $\mu \mathrm{molc} / \mathrm{g}$ & $0-5 \mathrm{~cm}$ & Control & $\overline{8.91(6.68)}$ & $\overline{12.78(9.54)}$ & $7.39(3.56)$ \\
\hline $\mathrm{Fe}^{3+}$ & $\mu \mathrm{molc} / \mathrm{g}$ & $0-5 \mathrm{~cm}$ & Limed & $6.87(2.95)$ & $4.72(5.36)$ & $1.55(1.49)$ \\
\hline $\mathrm{Fe}^{3+}$ & $\mu \mathrm{molc} / \mathrm{g}$ & $5-10 \mathrm{~cm}$ & Control & $3.9(4.54)$ & $\overline{7.83(4.23)}$ & $\overline{4.39(2.41)}$ \\
\hline $\mathrm{Fe}^{3+}$ & $\mu \mathrm{molc} / \mathrm{g}$ & $5-10 \mathrm{~cm}$ & Limed & $4.29(3.17)$ & $6.43(4.87)$ & $2.4(2.85)$ \\
\hline $\mathrm{Fe}^{3+}$ & $\mu \mathrm{molc} / \mathrm{g}$ & $10-30 \mathrm{~cm}$ & Control & $1.34(1.73)$ & $1.41(1.52)$ & $\overline{0.77(0.71)}$ \\
\hline $\mathrm{Fe}^{3+}$ & $\mu \mathrm{molc} / \mathrm{g}$ & $10-30 \mathrm{~cm}$ & Limed & $0.77(0.48)$ & $1.81(1.88)$ & $0.78(0.73)$ \\
\hline $\mathrm{Fe}^{3+}$ & $\mu \mathrm{molc} / \mathrm{g}$ & $30-60 \mathrm{~cm}$ & Control & $0.33(0.62)$ & $0.98(0.66)$ & $0.23(0.27)$ \\
\hline $\mathrm{Fe}^{3+}$ & $\mu \mathrm{molc} / \mathrm{g}$ & $30-60 \mathrm{~cm}$ & Limed & $0.08(0.06)$ & $1.13(1.58)$ & $0.36(0.74)$ \\
\hline $\mathrm{H}^{+}$ & $\mu \mathrm{molc} / \mathrm{g}$ & $0-5 \mathrm{~cm}$ & Control & $11.87(3.16)$ & 17.77 (7.99) & $18.16(11.02)$ \\
\hline $\mathrm{H}^{+}$ & $\mu \mathrm{molc} / \mathrm{g}$ & $0-5 \mathrm{~cm}$ & Limed & $13.5(6.36)$ & $4.55(5.9)$ & $3.03(4.05)$ \\
\hline $\mathrm{H}^{+}$ & $\mu \mathrm{molc} / \mathrm{g}$ & $5-10 \mathrm{~cm}$ & Control & $7.11(5.64)$ & $\overline{7.69(4.62)}$ & $\overline{9.05(6.44)}$ \\
\hline $\mathrm{H}^{+}$ & $\mu$ molc/g & $5-10 \mathrm{~cm}$ & Limed & $6.88(4.95)$ & $5.1(4.17)$ & $3.78(3.78)$ \\
\hline $\mathrm{H}^{+}$ & $\mu \mathrm{molc} / \mathrm{g}$ & $10-30 \mathrm{~cm}$ & Control & $2.42(1.47)$ & $2.47(3.16)$ & $\overline{2.11(1.85)}$ \\
\hline $\mathrm{H}^{+}$ & $\mu \mathrm{molc} / \mathrm{g}$ & $10-30 \mathrm{~cm}$ & Limed & $1.71(0.65)$ & $1.36(1.36)$ & $1.7(1.65)$ \\
\hline $\mathrm{H}^{+}$ & $\mu \mathrm{molc} / \mathrm{g}$ & $30-60 \mathrm{~cm}$ & Control & $1.17(0.56)$ & $0.69(1.01)$ & $0.72(0.62)$ \\
\hline $\mathrm{H}^{+}$ & $\mu \mathrm{molc} / \mathrm{g}$ & $30-60 \mathrm{~cm}$ & Limed & $0.85(0.82)$ & $0.58(0.64)$ & $0.62(0.58)$ \\
\hline $\mathrm{K}$ & $\mathrm{g} / \mathrm{kg}$ & O-layer & Control & $0.86(0.22)$ & $0.99(0.15)$ & $1.05(0.28)$ \\
\hline $\mathrm{K}$ & $\mathrm{g} / \mathrm{kg}$ & O-layer & Limed & $1.17(0.26)$ & $1.29(0.22)$ & $1.22(0.37)$ \\
\hline $\mathrm{K}^{+}$ & $\mu \mathrm{molc} / \mathrm{g}$ & $0-5 \mathrm{~cm}$ & Control & $0.83(0.42)$ & $0.74(0.35)$ & $1.03(0.63)$ \\
\hline $\mathrm{K}^{+}$ & $\mu \mathrm{molc} / \mathrm{g}$ & $0-5 \mathrm{~cm}$ & Limed & $0.7(0.31)$ & $0.96(0.33)$ & $0.96(0.41)$ \\
\hline $\mathrm{K}^{+}$ & $\mu \mathrm{molc} / \mathrm{g}$ & $5-10 \mathrm{~cm}$ & Control & $0.52(0.22)$ & $0.49(0.15)$ & $0.57(0.18)$ \\
\hline $\mathrm{K}^{+}$ & $\mu$ molc/g & $5-10 \mathrm{~cm}$ & Limed & $0.52(0.21)$ & $0.59(0.27)$ & $0.56(0.17)$ \\
\hline $\mathrm{K}^{+}$ & $\mu$ molc/g & $10-30 \mathrm{~cm}$ & Control & $0.42(0.27)$ & $0.43(0.13)$ & $0.45(0.16)$ \\
\hline $\mathrm{K}^{+}$ & $\mu$ molc/g & $10-30 \mathrm{~cm}$ & Limed & $0.47(0.18)$ & $0.48(0.2)$ & $0.49(0.15)$ \\
\hline $\mathrm{K}^{+}$ & $\mu \mathrm{molc} / \mathrm{g}$ & $30-60 \mathrm{~cm}$ & Control & $0.68(0.59)$ & $0.65(0.36)$ & $0.75(0.68)$ \\
\hline $\mathrm{K}^{+}$ & $\mu \mathrm{molc} / \mathrm{g}$ & $30-60 \mathrm{~cm}$ & Limed & $0.7(0.58)$ & $0.72(0.39)$ & $0.61(0.37)$ \\
\hline $\mathrm{Mn}$ & $\mathrm{g} / \mathrm{kg}$ & O-layer & Control & $0.85(0.69)$ & $0.87(0.51)$ & $1.21(0.96)$ \\
\hline Mn & $\mathrm{g} / \mathrm{kg}$ & O-layer & Limed & $0.94(0.6)$ & $2.12(1.3)$ & $1.84(1.19)$ \\
\hline $\mathrm{Mn}^{2+}$ & $\mu \mathrm{molc} / \mathrm{g}$ & $0-5 \mathrm{~cm}$ & Control & $0.92(1.43)$ & $\overline{1.05(1.46)}$ & $\overline{1.39(1.31)}$ \\
\hline $\mathrm{Mn}^{2+}$ & $\mu$ molc/g & $0-5 \mathrm{~cm}$ & Limed & $1.7(1.16)$ & $3.66(3.15)$ & $4.8(3.27)$ \\
\hline $\mathrm{Mn}^{2+}$ & $\mu$ molc/g & $5-10 \mathrm{~cm}$ & Control & $2.09(3.04)$ & $1.53(1.31)$ & $\overline{1.48(1.47)}$ \\
\hline $\mathrm{Mn}^{2+}$ & $\mu$ molc/g & $5-10 \mathrm{~cm}$ & Limed & $2.33(1.77)$ & $2.33(1.71)$ & $2.36(1.95)$ \\
\hline $\mathrm{Mn}^{2+}$ & $\mu \mathrm{molc} / \mathrm{g}$ & $10-30 \mathrm{~cm}$ & Control & $1.12(1.38)$ & $2.73(1.82)$ & $2.09(2.14)$ \\
\hline $\mathrm{Mn}^{2+}$ & $\mu$ molc/g & $10-30 \mathrm{~cm}$ & Limed & $1.9(1.16)$ & 2.64 (1.41) & $2.12(1.47)$ \\
\hline $\mathrm{Mn}^{2+}$ & $\mu \mathrm{molc} / \mathrm{g}$ & $30-60 \mathrm{~cm}$ & Control & $0.85(1.01)$ & $2.14(0.78)$ & $1.26(0.77)$ \\
\hline $\mathrm{Mn}^{2+}$ & $\mu \mathrm{molc} / \mathrm{g}$ & $30-60 \mathrm{~cm}$ & Limed & $1.17(0.98)$ & $2.21(1.29)$ & $1.57(1.51)$ \\
\hline $\mathrm{Na}$ & $\mathrm{g} / \mathrm{kg}$ & O-layer & Control & $0.1(0.02)$ & $0.16(0.03)$ & $0.14(0.07)$ \\
\hline $\mathrm{Na}$ & $\mathrm{g} / \mathrm{kg}$ & O-layer & Limed & $0.1(0.03)$ & $0.16(0.04)$ & $0.15(0.14)$ \\
\hline $\mathrm{Na}^{+}$ & $\mu \mathrm{molc} / \mathrm{g}$ & $0-5 \mathrm{~cm}$ & Control & $0.24(0.05)$ & $0.82(0.47)$ & $1.06(0.42)$ \\
\hline $\mathrm{Na}^{+}$ & $\mu$ molc/g & $0-5 \mathrm{~cm}$ & Limed & $0.31(0.21)$ & $0.68(0.27)$ & $1.26(0.59)$ \\
\hline $\mathrm{Na}^{+}$ & $\mu$ molc/g & $5-10 \mathrm{~cm}$ & Control & $0.27(0.1)$ & $0.7(0.33)$ & $0.8(0.34)$ \\
\hline $\mathrm{Na}^{+}$ & $\mu \mathrm{molc} / \mathrm{g}$ & $5-10 \mathrm{~cm}$ & Limed & $0.21(0.07)$ & $0.62(0.26)$ & $0.9(0.38)$ \\
\hline $\mathrm{Na}^{+}$ & $\mu$ molc/g & $10-30 \mathrm{~cm}$ & Control & $0.19(0.18)$ & $0.48(0.27)$ & $0.51(0.22)$ \\
\hline $\mathrm{Na}^{+}$ & $\mu \mathrm{molc} / \mathrm{g}$ & $10-30 \mathrm{~cm}$ & Limed & $0.17(0.08)$ & $0.45(0.28)$ & $0.65(0.32)$ \\
\hline $\mathrm{Na}^{+}$ & $\mu \mathrm{molc} / \mathrm{g}$ & $30-60 \mathrm{~cm}$ & Control & $0.31(0.17)$ & $0.45(0.23)$ & $0.49(0.21)$ \\
\hline $\mathrm{Na}^{+}$ & $\mu$ molc/g & $30-60 \mathrm{~cm}$ & Limed & $0.2(0.16)$ & $0.6(0.45)$ & $0.57(0.64)$ \\
\hline $\mathrm{N}_{\text {tot }}$ & $\mathrm{g} / \mathrm{kg}$ & O-layer & Control & $15.26(3.14)$ & $15.77(1.83)$ & $13.91(2.43)$ \\
\hline $\mathrm{N}_{\text {tot }}$ & $\mathrm{g} / \mathrm{kg}$ & O-layer & Limed & $11.8(3.86)$ & $12.08(3.27)$ & $12.05(2.33)$ \\
\hline $\mathrm{N}_{\text {tot }}$ & $\mathrm{g} / \mathrm{kg}$ & $0-5 \mathrm{~cm}$ & Control & $2.02(1.36)$ & $\overline{2.12(1.08)}$ & $\overline{2.52(1.44)}$ \\
\hline $\mathrm{N}_{\text {tot }}$ & $\mathrm{g} / \mathrm{kg}$ & $0-5 \mathrm{~cm}$ & Limed & $1.77(0.51)$ & $2.79(1)$ & $3.27(1.51)$ \\
\hline
\end{tabular}


Table A1. Cont.

\begin{tabular}{|c|c|c|c|c|c|c|}
\hline Parameter & Unit & Depth & Treatment & 2003 & 2010 & 2015 \\
\hline $\mathrm{N}_{\text {tot }}$ & $\mathrm{g} / \mathrm{kg}$ & $5-10 \mathrm{~cm}$ & Control & $1.1(0.64)$ & $1.12(0.49)$ & $1.26(0.56)$ \\
\hline $\mathrm{N}_{\text {tot }}$ & $\mathrm{g} / \mathrm{kg}$ & $5-10 \mathrm{~cm}$ & Limed & $1.13(0.42)$ & $1.3(0.41)$ & $1.62(0.64)$ \\
\hline $\mathrm{N}_{\text {tot }}$ & $\mathrm{g} / \mathrm{kg}$ & $10-30 \mathrm{~cm}$ & Control & $0.61(0.37)$ & $0.7(0.31)$ & $\overline{0.69(0.33)}$ \\
\hline $\mathrm{N}_{\text {tot }}$ & $\mathrm{g} / \mathrm{kg}$ & $10-30 \mathrm{~cm}$ & Limed & $0.81(0.36)$ & $0.77(0.24)$ & $0.85(0.3)$ \\
\hline $\mathrm{N}_{\text {tot }}$ & $\mathrm{g} / \mathrm{kg}$ & $30-60 \mathrm{~cm}$ & Control & $0.34(0.24)$ & $0.43(0.21)$ & $0.41(0.19)$ \\
\hline $\mathrm{N}_{\text {tot }}$ & $\mathrm{g} / \mathrm{kg}$ & $30-60 \mathrm{~cm}$ & Limed & $0.5(0.32)$ & $0.45(0.2)$ & $0.49(0.22)$ \\
\hline $\mathrm{pH}-\mathrm{KCl}$ & & O-layer & Control & $2.63(0.54)$ & $2.82(0.34)$ & $3.09(0.77)$ \\
\hline $\mathrm{pH}-\mathrm{KCl}$ & & O-layer & Limed & $3.01(0.46)$ & $5.56(0.46)$ & $4.3(0.7)$ \\
\hline $\mathrm{pH}-\mathrm{KCl}$ & & $0-5 \mathrm{~cm}$ & Control & $2.89(0.13)$ & $\overline{2.97(0.14)}$ & $2 . \overline{94(0.62)}$ \\
\hline $\mathrm{pH}-\mathrm{KCl}$ & & $0-5 \mathrm{~cm}$ & Limed & $2.9(0.19)$ & $3.72(0.98)$ & $3.73(1.07)$ \\
\hline $\mathrm{pH}-\mathrm{KCl}$ & & $5-10 \mathrm{~cm}$ & Control & $3.11(0.33)$ & $3.25(0.27)$ & $\overline{3.17(0.32)}$ \\
\hline $\mathrm{pH}-\mathrm{KCl}$ & & $5-10 \mathrm{~cm}$ & Limed & $3.18(0.23)$ & $3.47(0.32)$ & $3.6(0.72)$ \\
\hline $\mathrm{pH}-\mathrm{KCl}$ & & $10-30 \mathrm{~cm}$ & Control & $3.47(0.35)$ & $\overline{3.62(0.34)}$ & $3.66(0.26)$ \\
\hline $\mathrm{pH}-\mathrm{KCl}$ & & $10-30 \mathrm{~cm}$ & Limed & $3.69(0.17)$ & $3.83(0.22)$ & $3.78(0.2)$ \\
\hline $\mathrm{pH}-\mathrm{KCl}$ & & $30-60 \mathrm{~cm}$ & Control & $3.78(0.28)$ & $3.94(0.25)$ & $3.92(0.18)$ \\
\hline $\mathrm{pH}-\mathrm{KCl}$ & & $30-60 \mathrm{~cm}$ & Limed & $3.84(0.28)$ & $3.96(0.23)$ & $3.97(0.19)$ \\
\hline
\end{tabular}

Table A2. G2 study site historic development of $\mathrm{pH}-\mathrm{KCl}, \mathrm{Mg}, \mathrm{K}, \mathrm{Na}, \mathrm{Fe}, \mathrm{Mn}, \mathrm{H}, \mathrm{C}$ and $\mathrm{N}$ in 2003-2015; given are group means with standard deviations. Marked bold—significant differences between current and previous sampling campaign, underline-limed plots significantly different from control.

\begin{tabular}{|c|c|c|c|c|c|c|}
\hline Parameter & Unit & Depth & Treatment & 2003 & 2010 & 2015 \\
\hline $\mathrm{C} / \mathrm{N}$ & & O-layer & Control & $25.53(4.56)$ & $25.4(3.53)$ & $24.15(3.78)$ \\
\hline $\mathrm{C} / \mathrm{N}$ & & O-layer & Limed & $26.12(3.17)$ & $23.63(2.78)$ & $23.69(3.6)$ \\
\hline $\mathrm{C} / \mathrm{N}$ & & $0-5 \mathrm{~cm}$ & Control & $18.86(3.68)$ & $19.16(4.49)$ & $17.48(1.75)$ \\
\hline $\mathrm{C} / \mathrm{N}$ & & $0-5 \mathrm{~cm}$ & Limed & $18.12(1.37)$ & $17.82(2.02)$ & $17.73(1.85)$ \\
\hline $\mathrm{C} / \mathrm{N}$ & & $5-10 \mathrm{~cm}$ & Control & $17.9(3.97)$ & $17.82(5.97)$ & $16.8(1.85)$ \\
\hline $\mathrm{C} / \mathrm{N}$ & & $5-10 \mathrm{~cm}$ & Limed & $17.86(1.73)$ & $17.23(1.7)$ & $17.29(1.91)$ \\
\hline $\mathrm{C} / \mathrm{N}$ & & $10-30 \mathrm{~cm}$ & Control & $15.52(2.04)$ & $14.63(3.34)$ & $14.11(1.54)$ \\
\hline $\mathrm{C} / \mathrm{N}$ & & $10-30 \mathrm{~cm}$ & Limed & $14.96(2.56)$ & $14.86(1.98)$ & $14.62(2.21)$ \\
\hline $\mathrm{C} / \mathrm{N}$ & & $30-60 \mathrm{~cm}$ & Control & $10.76(1.26)$ & $9.47(2.73)$ & $9.98(2.1)$ \\
\hline $\mathrm{C} / \mathrm{N}$ & & $30-60 \mathrm{~cm}$ & Limed & $11.18(1.54)$ & $10.7(2.78)$ & $10.47(3.16)$ \\
\hline $\mathrm{C}_{\text {tot }}$ & $\mathrm{g} / \mathrm{kg}$ & O-layer & Control & $402.22(51.68)$ & $365.85(86.95)$ & $335.14(79.08)$ \\
\hline $\mathrm{C}_{\text {tot }}$ & $\mathrm{g} / \mathrm{kg}$ & O-layer & Limed & $365.33(15.88)$ & $304.49(84.66)$ & 291.65 (61.61) \\
\hline $\mathrm{C}_{\text {tot }}$ & $\mathrm{g} / \mathrm{kg}$ & $0-5 \mathrm{~cm}$ & Control & $44.42(6.69)$ & $\overline{49.06(22.27)}$ & $\overline{57.97(29.58)}$ \\
\hline $\mathrm{C}_{\text {tot }}$ & $\mathrm{g} / \mathrm{kg}$ & $0-5 \mathrm{~cm}$ & Limed & $62.02(13.52)$ & $39.11(12.21)$ & $50.58(18.43)$ \\
\hline$C_{\text {tot }}$ & $\mathrm{g} / \mathrm{kg}$ & $5-10 \mathrm{~cm}$ & Control & $24.22(3.33)$ & $24.15(8.28)$ & $27.71(9.24)$ \\
\hline $\mathrm{C}_{\text {tot }}$ & $\mathrm{g} / \mathrm{kg}$ & $5-10 \mathrm{~cm}$ & Limed & $27.96(6.64)$ & $25.02(5.59)$ & $27.24(9.95)$ \\
\hline $\mathrm{C}_{\text {tot }}$ & $\mathrm{g} / \mathrm{kg}$ & $10-30 \mathrm{~cm}$ & Control & $13.94(3.76)$ & $11.81(3.93)$ & $13.73(3.53)$ \\
\hline $\mathrm{C}_{\text {tot }}$ & $\mathrm{g} / \mathrm{kg}$ & $10-30 \mathrm{~cm}$ & Limed & $13.16(3.91)$ & $14.33(5.38)$ & $13.84(6.01)$ \\
\hline $\mathrm{C}_{\text {tot }}$ & $\mathrm{g} / \mathrm{kg}$ & $30-60 \mathrm{~cm}$ & Control & $4.98(1.28)$ & $4.98(3.76)$ & $5.95(3.88)$ \\
\hline $\mathrm{C}_{\text {tot }}$ & $\mathrm{g} / \mathrm{kg}$ & $30-60 \mathrm{~cm}$ & Limed & $6.58(5.08)$ & $6.55(4.73)$ & $6.46(5.69)$ \\
\hline $\mathrm{Fe}$ & $\mathrm{g} / \mathrm{kg}$ & O-layer & Control & $4.03(2.26)$ & $5.71(3.98)$ & $5.35(3.26)$ \\
\hline $\mathrm{Fe}$ & $\mathrm{g} / \mathrm{kg}$ & O-layer & Limed & $4.93(1.72)$ & $7.44(3.53)$ & 7.49 (3.19) \\
\hline $\mathrm{Fe}^{3+}$ & $\mu$ molc/g & $0-5 \mathrm{~cm}$ & Control & $9.22(6.3)$ & $13.22(7.92)$ & $8.37(4.97)$ \\
\hline $\mathrm{Fe}^{3+}$ & $\mu \mathrm{molc} / \mathrm{g}$ & $0-5 \mathrm{~cm}$ & Limed & $15.37(7.55)$ & $9.64(7.68)$ & $3.56(2.73)$ \\
\hline $\mathrm{Fe}^{3+}$ & $\mu \mathrm{molc} / \mathrm{g}$ & $5-10 \mathrm{~cm}$ & Control & $3.81(5.3)$ & $3.7(2.54)$ & $2.46(2.37)$ \\
\hline $\mathrm{Fe}^{3+}$ & $\mu$ molc/g & $5-10 \mathrm{~cm}$ & Limed & $5.42(4.82)$ & $3.82(2.71)$ & $1.37(1.15)$ \\
\hline $\mathrm{Fe}^{3+}$ & $\mu \mathrm{molc} / \mathrm{g}$ & $10-30 \mathrm{~cm}$ & Control & $0.45(0.43)$ & $0.61(0.36)$ & $0.3(0.2)$ \\
\hline $\mathrm{Fe}^{3+}$ & $\mu$ molc/g & $10-30 \mathrm{~cm}$ & Limed & $0.44(0.49)$ & $1.07(0.78)$ & $0.3(0.26)$ \\
\hline $\mathrm{Fe}^{3+}$ & $\mu$ molc/g & $30-60 \mathrm{~cm}$ & Control & $0.05(0.03)$ & $\overline{0.35(0.16)}$ & $0.08(0.03)$ \\
\hline $\mathrm{Fe}^{3+}$ & $\mu \mathrm{molc} / \mathrm{g}$ & $30-60 \mathrm{~cm}$ & Limed & $0.06(0.06)$ & $0.54(0.46)$ & $0.1(0.09)$ \\
\hline $\mathrm{H}^{+}$ & $\mu \mathrm{molc} / \mathrm{g}$ & $0-5 \mathrm{~cm}$ & Control & $11.04(7.25)$ & $12.8(8.47)$ & $13.6(9.63)$ \\
\hline $\mathrm{H}^{+}$ & $\mu \mathrm{molc} / \mathrm{g}$ & $0-5 \mathrm{~cm}$ & Limed & $18.26(4.18)$ & $5.8(4.6)$ & 4.89 (3.75) \\
\hline
\end{tabular}


Table A2. Cont.

\begin{tabular}{|c|c|c|c|c|c|c|}
\hline Parameter & Unit & Depth & Treatment & 2003 & 2010 & 2015 \\
\hline $\mathrm{H}^{+}$ & $\mu \mathrm{molc} / \mathrm{g}$ & $5-10 \mathrm{~cm}$ & Control & $4.84(3.28)$ & $3.23(2.01)$ & $4.6(4.47)$ \\
\hline $\mathrm{H}^{+}$ & $\mu \mathrm{molc} / \mathrm{g}$ & $5-10 \mathrm{~cm}$ & Limed & $6.99(3.75)$ & $2.84(1.48)$ & $2.94(1.66)$ \\
\hline $\mathrm{H}^{+}$ & $\mu \mathrm{molc} / \mathrm{g}$ & $10-30 \mathrm{~cm}$ & Control & $1.93(0.97)$ & $0.85(0.52)$ & $1.16(0.68)$ \\
\hline $\mathrm{H}^{+}$ & $\mu \mathrm{molc} / \mathrm{g}$ & $10-30 \mathrm{~cm}$ & Limed & $2(0.97)$ & $1.12(0.54)$ & $1.3(0.67)$ \\
\hline $\mathrm{H}^{+}$ & $\mu \mathrm{molc} / \mathrm{g}$ & $30-60 \mathrm{~cm}$ & Control & $1.34(0.83)$ & $0.96(0.78)$ & $0.67(0.53)$ \\
\hline $\mathrm{H}^{+}$ & $\mu \mathrm{molc} / \mathrm{g}$ & $30-60 \mathrm{~cm}$ & Limed & $1.53(0.71)$ & $1.08(0.53)$ & $1.12(0.72)$ \\
\hline $\mathrm{K}$ & $\mathrm{g} / \mathrm{kg}$ & O-layer & Control & $1.41(1.02)$ & $1.59(0.8)$ & $\overline{1.24(0.46)}$ \\
\hline K & $\mathrm{g} / \mathrm{kg}$ & O-layer & Limed & $1.69(0.67)$ & $2.04(0.88)$ & $1.61(0.72)$ \\
\hline $\mathrm{K}^{+}$ & $\mu \mathrm{molc} / \mathrm{g}$ & $0-5 \mathrm{~cm}$ & Control & $0.8(0.18)$ & $1.12(0.73)$ & $\overline{1.46(1.17)}$ \\
\hline $\mathrm{K}^{+}$ & $\mu \mathrm{molc} / \mathrm{g}$ & $0-5 \mathrm{~cm}$ & Limed & $1(0.43)$ & $1(0.34)$ & $1.22(0.66)$ \\
\hline $\mathrm{K}^{+}$ & $\mu \mathrm{molc} / \mathrm{g}$ & $5-10 \mathrm{~cm}$ & Control & $0.7(0.31)$ & $0.71(0.22)$ & $0.84(0.2)$ \\
\hline $\mathrm{K}^{+}$ & $\mu \mathrm{molc} / \mathrm{g}$ & $5-10 \mathrm{~cm}$ & Limed & $0.71(0.31)$ & $0.9(0.32)$ & $0.85(0.34)$ \\
\hline $\mathrm{K}^{+}$ & $\mu \mathrm{molc} / \mathrm{g}$ & $10-30 \mathrm{~cm}$ & Control & $0.64(0.23)$ & $0.78(0.24)$ & $0.78(0.26)$ \\
\hline $\mathrm{K}^{+}$ & $\mu \mathrm{molc} / \mathrm{g}$ & $10-30 \mathrm{~cm}$ & Limed & $0.78(0.41)$ & $0.98(0.41)$ & $0.89(0.34)$ \\
\hline $\mathrm{K}^{+}$ & $\mu \mathrm{molc} / \mathrm{g}$ & $30-60 \mathrm{~cm}$ & Control & $1.02(0.29)$ & $1.16(0.31)$ & $0.97(0.31)$ \\
\hline $\mathrm{K}^{+}$ & $\mu \mathrm{molc} / \mathrm{g}$ & $30-60 \mathrm{~cm}$ & Limed & $1.1(0.61)$ & $1.43(0.58)$ & $1.13(0.43)$ \\
\hline Mn & $\mathrm{g} / \mathrm{kg}$ & O-layer & Control & $0.85(0.81)$ & $1.08(0.79)$ & $1.01(0.94)$ \\
\hline Mn & $\mathrm{g} / \mathrm{kg}$ & O-layer & Limed & $1.35(1.12)$ & $2.25(1.32)$ & $2.28(1.3)$ \\
\hline $\mathrm{Mn}^{2+}$ & $\mu \mathrm{molc} / \mathrm{g}$ & $0-5 \mathrm{~cm}$ & Control & $2.93(2.13)$ & $\overline{3.5(3.61)}$ & $\overline{3.28(2.75)}$ \\
\hline $\mathrm{Mn}^{2+}$ & $\mu \mathrm{molc} / \mathrm{g}$ & $0-5 \mathrm{~cm}$ & Limed & $3.57(3.49)$ & $4.27(3.46)$ & $5.3(4.16)$ \\
\hline $\mathrm{Mn}^{2+}$ & $\mu \mathrm{molc} / \mathrm{g}$ & $5-10 \mathrm{~cm}$ & Control & $4.52(3.41)$ & $6.5(4.53)$ & $4.19(4.22)$ \\
\hline $\mathrm{Mn}^{2+}$ & $\mu \mathrm{molc} / \mathrm{g}$ & $5-10 \mathrm{~cm}$ & Limed & $4.04(2.04)$ & $5.44(3.03)$ & 4.61 (3.39) \\
\hline $\mathrm{Mn}^{2+}$ & $\mu \mathrm{molc} / \mathrm{g}$ & $10-30 \mathrm{~cm}$ & Control & $3.7(2.41)$ & $4.68(3.25)$ & $3.16(2.24)$ \\
\hline $\mathrm{Mn}^{2+}$ & $\mu \mathrm{molc} / \mathrm{g}$ & $10-30 \mathrm{~cm}$ & Limed & $3.47(1.38)$ & $4.88(3.06)$ & $3.83(2.71)$ \\
\hline $\mathrm{Mn}^{2+}$ & $\mu \mathrm{molc} / \mathrm{g}$ & $30-60 \mathrm{~cm}$ & Control & $2(1.44)$ & $3.14(2.43)$ & $2.41(1.92)$ \\
\hline $\mathrm{Mn}^{2+}$ & $\mu \mathrm{molc} / \mathrm{g}$ & $30-60 \mathrm{~cm}$ & Limed & $1.78(1.05)$ & $3.71(2.16)$ & 2.45 (1.69) \\
\hline $\mathrm{Na}$ & $\mathrm{g} / \mathrm{kg}$ & O-layer & Control & $0.1(0.06)$ & $0.13(0.05)$ & $0.13(0.05)$ \\
\hline $\mathrm{Na}$ & $\mathrm{g} / \mathrm{kg}$ & O-layer & Limed & $0.1(0.06)$ & $0.18(0.05)$ & $0.13(0.05)$ \\
\hline $\mathrm{Na}^{+}$ & $\mu \mathrm{molc} / \mathrm{g}$ & $0-5 \mathrm{~cm}$ & Control & $0.43(0.22)$ & $0.83(0.57)$ & $1.11(0.29)$ \\
\hline $\mathrm{Na}^{+}$ & $\mu \mathrm{molc} / \mathrm{g}$ & $0-5 \mathrm{~cm}$ & Limed & $0.41(0.16)$ & $0.72(0.24)$ & $1.04(0.4)$ \\
\hline $\mathrm{Na}^{+}$ & $\mu \mathrm{molc} / \mathrm{g}$ & $5-10 \mathrm{~cm}$ & Control & $0.43(0.34)$ & $0.68(0.34)$ & $0.86(0.36)$ \\
\hline $\mathrm{Na}^{+}$ & $\mu \mathrm{molc} / \mathrm{g}$ & $5-10 \mathrm{~cm}$ & Limed & $0.36(0.21)$ & $0.57(0.21)$ & $0.8(0.32)$ \\
\hline $\mathrm{Na}^{+}$ & $\mu \mathrm{molc} / \mathrm{g}$ & $10-30 \mathrm{~cm}$ & Control & $0.31(0.14)$ & $0.33(0.18)$ & $0.48(0.15)$ \\
\hline $\mathrm{Na}^{+}$ & $\mu \mathrm{molc} / \mathrm{g}$ & $10-30 \mathrm{~cm}$ & Limed & $0.24(0.08)$ & $0.44(0.24)$ & $0.56(0.26)$ \\
\hline $\mathrm{Na}^{+}$ & $\mu \mathrm{molc} / \mathrm{g}$ & $30-60 \mathrm{~cm}$ & Control & $0.4(0.1)$ & $0.46(0.27)$ & $0.37(0.13)$ \\
\hline $\mathrm{Na}^{+}$ & $\mu \mathrm{molc} / \mathrm{g}$ & $30-60 \mathrm{~cm}$ & Limed & $0.2(0.12)$ & $0.44(0.28)$ & $0.43(0.2)$ \\
\hline $\mathrm{N}_{\text {tot }}$ & $\mathrm{g} / \mathrm{kg}$ & O-layer & Control & $15.98(2.38)$ & $14.53(3.27)$ & $13.88(2.77)$ \\
\hline $\mathrm{N}_{\text {tot }}$ & $\mathrm{g} / \mathrm{kg}$ & O-layer & Limed & $14.09(1.1)$ & $12.92(3.5)$ & $12.47(2.73)$ \\
\hline $\mathrm{N}_{\text {tot }}$ & $\mathrm{g} / \mathrm{kg}$ & $0-5 \mathrm{~cm}$ & Control & $2.38(0.22)$ & $2.57(1.14)$ & 3.28 (1.52) \\
\hline $\mathrm{N}_{\text {tot }}$ & $\mathrm{g} / \mathrm{kg}$ & $0-5 \mathrm{~cm}$ & Limed & $3.46(0.91)$ & $2.19(0.62)$ & 2.89 (1.11) \\
\hline $\mathrm{N}_{\text {tot }}$ & $\mathrm{g} / \mathrm{kg}$ & $5-10 \mathrm{~cm}$ & Control & $\overline{1.37(0.14)}$ & $1.37(0.35)$ & $1.65(0.53)$ \\
\hline $\mathrm{N}_{\text {tot }}$ & $\mathrm{g} / \mathrm{kg}$ & $5-10 \mathrm{~cm}$ & Limed & $1.57(0.37)$ & $1.45(0.3)$ & $1.58(0.59)$ \\
\hline $\mathrm{N}_{\text {tot }}$ & $\mathrm{g} / \mathrm{kg}$ & $10-30 \mathrm{~cm}$ & Control & $0.9(0.24)$ & $0.83(0.28)$ & $0.98(0.27)$ \\
\hline $\mathrm{N}_{\text {tot }}$ & $\mathrm{g} / \mathrm{kg}$ & $10-30 \mathrm{~cm}$ & Limed & $0.89(0.23)$ & $0.95(0.3)$ & $0.94(0.35)$ \\
\hline $\mathrm{N}_{\text {tot }}$ & $\mathrm{g} / \mathrm{kg}$ & $30-60 \mathrm{~cm}$ & Control & $0.46(0.1)$ & $0.5(0.22)$ & $0.56(0.25)$ \\
\hline $\mathrm{N}_{\text {tot }}$ & $\mathrm{g} / \mathrm{kg}$ & $30-60 \mathrm{~cm}$ & Limed & $0.56(0.36)$ & $0.57(0.29)$ & $0.56(0.32)$ \\
\hline $\mathrm{pH}-\mathrm{KCl}$ & & O-layer & Control & $2.77(0.43)$ & $2.96(0.39)$ & $2.97(0.62)$ \\
\hline $\mathrm{pH}-\mathrm{KCl}$ & & O-layer & Limed & $3.06(0.64)$ & $4.53(0.79)$ & $4.37(0.79)$ \\
\hline $\mathrm{pH}-\mathrm{KCl}$ & & $0-5 \mathrm{~cm}$ & Control & $2.95(0.29)$ & $\overline{3.1(0.22)}$ & $\overline{3.09(0.32)}$ \\
\hline $\mathrm{pH}-\mathrm{KCl}$ & & $0-5 \mathrm{~cm}$ & Limed & $2.83(0.11)$ & $3.42(0.39)$ & $3.54(0.66)$ \\
\hline $\mathrm{pH}-\mathrm{KCl}$ & & $5-10 \mathrm{~cm}$ & Control & $3.29(0.31)$ & $\overline{3.53(0.18)}$ & $\overline{3.42(0.29)}$ \\
\hline $\mathrm{pH}-\mathrm{KCl}$ & & $5-10 \mathrm{~cm}$ & Limed & $3.18(0.28)$ & $3.59(0.15)$ & $3.62(0.22)$ \\
\hline $\mathrm{pH}-\mathrm{KCl}$ & & $10-30 \mathrm{~cm}$ & Control & $3.68(0.18)$ & $3.87(0.14)$ & $3.8(0.16)$ \\
\hline $\mathrm{pH}-\mathrm{KCl}$ & & $10-30 \mathrm{~cm}$ & Limed & $3.63(0.17)$ & $3.79(0.14)$ & $3.8(0.15)$ \\
\hline $\mathrm{pH}-\mathrm{KCl}$ & & $30-60 \mathrm{~cm}$ & Control & $3.74(0.23)$ & $3.8(0.18)$ & $3.88(0.19)$ \\
\hline $\mathrm{pH}-\mathrm{KCl}$ & & $30-60 \mathrm{~cm}$ & Limed & $3.63(0.19)$ & $3.76(0.14)$ & $3.8(0.19)$ \\
\hline
\end{tabular}


Table A3. G1 study site parameter $\mathrm{pH}-\mathrm{KCl}, \mathrm{Mg}, \mathrm{K}, \mathrm{Na}, \mathrm{Fe}, \mathrm{Mn}, \mathrm{H}, \mathrm{C}$ and $\mathrm{N}$ response ratios (RR) to time in 2003-2015.

\begin{tabular}{|c|c|c|c|c|c|c|c|}
\hline Parameter & Unit & Depth & Period & Treatment & RR Mean & RR SD & RR Range \\
\hline $\mathrm{C} / \mathrm{N}$ & & O-layer & 2003-2010 & Control & -1.88 & 1.88 & $-3.97-0.74$ \\
\hline $\mathrm{C} / \mathrm{N}$ & & O-layer & 2003-2010 & Limed & 0.29 & 3.28 & $-3.61-5.23$ \\
\hline $\mathrm{C} / \mathrm{N}$ & & O-layer & 2010-2015 & Control & -0.19 & 1.77 & $-2.96-1.7$ \\
\hline $\mathrm{C} / \mathrm{N}$ & & O-layer & 2010-2015 & Limed & 2.89 & 3.84 & $0.04-9.08$ \\
\hline $\mathrm{C} / \mathrm{N}$ & & $0-5 \mathrm{~cm}$ & $2003-2010$ & Control & 0.22 & 2.25 & $-1.9-3.92$ \\
\hline $\mathrm{C} / \mathrm{N}$ & & $0-5 \mathrm{~cm}$ & 2003-2010 & Limed & -0.59 & 1.52 & $-3.18-0.8$ \\
\hline $\mathrm{C} / \mathrm{N}$ & & $0-5 \mathrm{~cm}$ & 2010-2015 & Control & 0.45 & 4.24 & $-2.28-7.9$ \\
\hline $\mathrm{C} / \mathrm{N}$ & & $0-5 \mathrm{~cm}$ & 2010-2015 & Limed & -1.37 & 2.63 & $-4.89-2.1$ \\
\hline $\mathrm{C} / \mathrm{N}$ & & $5-10 \mathrm{~cm}$ & 2003-2010 & Control & -0.08 & 2.43 & $-2.25-3.35$ \\
\hline $\mathrm{C} / \mathrm{N}$ & & $5-10 \mathrm{~cm}$ & 2003-2010 & Limed & 1.59 & 2.06 & $-0.35-4.25$ \\
\hline $\mathrm{C} / \mathrm{N}$ & & $5-10 \mathrm{~cm}$ & 2010-2015 & Control & -0.01 & 3.74 & $-4.63-5.45$ \\
\hline $\mathrm{C} / \mathrm{N}$ & & $5-10 \mathrm{~cm}$ & 2010-2015 & Limed & -0.95 & 1.87 & $-3.13-1.85$ \\
\hline $\mathrm{C} / \mathrm{N}$ & & $10-30 \mathrm{~cm}$ & 2003-2010 & Control & -2.5 & 4.15 & $-8.8-0.7$ \\
\hline $\mathrm{C} / \mathrm{N}$ & & $10-30 \mathrm{~cm}$ & 2003-2010 & Limed & 1.65 & 2.09 & $-1.98-3.07$ \\
\hline $\mathrm{C} / \mathrm{N}$ & & $10-30 \mathrm{~cm}$ & 2010-2015 & Control & 0.39 & 2.04 & $-1.92-2.81$ \\
\hline $\mathrm{C} / \mathrm{N}$ & & $10-30 \mathrm{~cm}$ & 2010-2015 & Limed & -0.94 & 2.6 & $-3.54-2.72$ \\
\hline $\mathrm{C} / \mathrm{N}$ & & $30-60 \mathrm{~cm}$ & $2003-2010$ & Control & -4.3 & 6.68 & $-14.57-2.6$ \\
\hline $\mathrm{C} / \mathrm{N}$ & & $30-60 \mathrm{~cm}$ & 2003-2010 & Limed & 2.41 & 4.18 & $-2.9-7.32$ \\
\hline $\mathrm{C} / \mathrm{N}$ & & $30-60 \mathrm{~cm}$ & 2010-2015 & Control & -0.07 & 3.08 & $-3.51-4.6$ \\
\hline $\mathrm{C} / \mathrm{N}$ & & $30-60 \mathrm{~cm}$ & 2010-2015 & Limed & -1.68 & 2.3 & $-4.3-1.2$ \\
\hline $\mathrm{C}_{\text {tot }}$ & $\mathrm{g} / \mathrm{kg}$ & O-layer & 2003-2010 & Control & 0 & 0.26 & $-0.24-0.38$ \\
\hline $\mathrm{C}_{\text {tot }}$ & $\mathrm{g} / \mathrm{kg}$ & O-layer & 2003-2010 & Limed & 0.28 & 0.81 & $-0.36-1.52$ \\
\hline $\mathrm{C}_{\text {tot }}$ & $\mathrm{g} / \mathrm{kg}$ & O-layer & 2010-2015 & Control & -0.12 & 0.09 & $-0.22--0.01$ \\
\hline $\mathrm{C}_{\text {tot }}$ & $\mathrm{g} / \mathrm{kg}$ & O-layer & 2010-2015 & Limed & 0.12 & 0.3 & $-0.25-0.58$ \\
\hline $\mathrm{C}_{\text {tot }}$ & $\mathrm{g} / \mathrm{kg}$ & $0-5 \mathrm{~cm}$ & 2003-2010 & Control & 0.31 & 0.46 & $-0.33-0.97$ \\
\hline $\mathrm{C}_{\text {tot }}$ & $\mathrm{g} / \mathrm{kg}$ & $0-5 \mathrm{~cm}$ & 2003-2010 & Limed & 0.61 & 0.51 & $0.1-1.35$ \\
\hline $\mathrm{C}_{\text {tot }}$ & $\mathrm{g} / \mathrm{kg}$ & $0-5 \mathrm{~cm}$ & 2010-2015 & Control & 0.28 & 0.52 & $-0.22-1.11$ \\
\hline $\mathrm{C}_{\text {tot }}$ & $\mathrm{g} / \mathrm{kg}$ & $0-5 \mathrm{~cm}$ & 2010-2015 & Limed & 0.08 & 0.17 & $-0.08-0.34$ \\
\hline $\mathrm{C}_{\text {tot }}$ & $\mathrm{g} / \mathrm{kg}$ & $5-10 \mathrm{~cm}$ & 2003-2010 & Control & 0.19 & 0.36 & $-0.22-0.64$ \\
\hline $\mathrm{C}_{\text {tot }}$ & $\mathrm{g} / \mathrm{kg}$ & $5-10 \mathrm{~cm}$ & 2003-2010 & Limed & 0.28 & 0.23 & $0.01-0.64$ \\
\hline $\mathrm{C}_{\text {tot }}$ & $\mathrm{g} / \mathrm{kg}$ & $5-10 \mathrm{~cm}$ & 2010-2015 & Control & 0.24 & 0.64 & $-0.27-1.33$ \\
\hline $\mathrm{C}_{\text {tot }}$ & $\mathrm{g} / \mathrm{kg}$ & $5-10 \mathrm{~cm}$ & 2010-2015 & Limed & 0.19 & 0.23 & $-0.03-0.54$ \\
\hline $\mathrm{C}_{\text {tot }}$ & $\mathrm{g} / \mathrm{kg}$ & $10-30 \mathrm{~cm}$ & 2003-2010 & Control & 0.17 & 0.4 & $-0.28-0.8$ \\
\hline $\mathrm{C}_{\text {tot }}$ & $\mathrm{g} / \mathrm{kg}$ & $10-30 \mathrm{~cm}$ & 2003-2010 & Limed & 0.11 & 0.26 & $-0.23-0.34$ \\
\hline$C_{\text {tot }}$ & $\mathrm{g} / \mathrm{kg}$ & $10-30 \mathrm{~cm}$ & 2010-2015 & Control & -0.01 & 0.22 & $-0.21-0.3$ \\
\hline $\mathrm{C}_{\text {tot }}$ & $\mathrm{g} / \mathrm{kg}$ & $10-30 \mathrm{~cm}$ & 2010-2015 & Limed & 0.07 & 0.37 & $-0.33-0.67$ \\
\hline $\mathrm{C}_{\text {tot }}$ & $\mathrm{g} / \mathrm{kg}$ & $30-60 \mathrm{~cm}$ & 2003-2010 & Control & 0.28 & 0.43 & $-0.13-0.97$ \\
\hline $\mathrm{C}_{\text {tot }}$ & $\mathrm{g} / \mathrm{kg}$ & $30-60 \mathrm{~cm}$ & 2003-2010 & Limed & 0.23 & 0.64 & $-0.27-1.34$ \\
\hline $\mathrm{C}_{\text {tot }}$ & $\mathrm{g} / \mathrm{kg}$ & $30-60 \mathrm{~cm}$ & 2010-2015 & Control & -0.08 & 0.27 & $-0.46-0.24$ \\
\hline $\mathrm{C}_{\text {tot }}$ & $\mathrm{g} / \mathrm{kg}$ & $30-60 \mathrm{~cm}$ & 2010-2015 & Limed & 0.06 & 0.4 & $-0.34-0.63$ \\
\hline $\mathrm{Fe}$ & $\mathrm{g} / \mathrm{kg}$ & O-layer & 2003-2010 & Control & 0.53 & 0.85 & $-0.2-1.81$ \\
\hline $\mathrm{Fe}$ & $\mathrm{g} / \mathrm{kg}$ & O-layer & 2003-2010 & Limed & 0.17 & 0.67 & $-0.66-0.84$ \\
\hline $\mathrm{Fe}$ & $\mathrm{g} / \mathrm{kg}$ & O-layer & 2010-2015 & Control & 0.39 & 0.65 & $-0.06-1.5$ \\
\hline $\mathrm{Fe}$ & $\mathrm{g} / \mathrm{kg}$ & O-layer & 2010-2015 & Limed & -0.2 & 0.28 & $-0.39-0.29$ \\
\hline $\mathrm{Fe}^{3+}$ & $\mu \mathrm{molc} / \mathrm{g}$ & $0-5 \mathrm{~cm}$ & 2003-2010 & Control & 0.79 & 0.92 & $-0.01-1.92$ \\
\hline $\mathrm{Fe}^{3+}$ & $\mu \mathrm{molc} / \mathrm{g}$ & $0-5 \mathrm{~cm}$ & 2003-2010 & Limed & -0.26 & 0.52 & $-0.88-0.3$ \\
\hline $\mathrm{Fe}^{3+}$ & $\mu \mathrm{molc} / \mathrm{g}$ & $0-5 \mathrm{~cm}$ & 2010-2015 & Control & 0.38 & 1.84 & $-0.6-3.67$ \\
\hline $\mathrm{Fe}^{3+}$ & $\mu \mathrm{molc} / \mathrm{g}$ & $0-5 \mathrm{~cm}$ & 2010-2015 & Limed & -0.44 & 0.6 & $-0.87-0.59$ \\
\hline $\mathrm{Fe}^{3+}$ & $\mu \mathrm{molc} / \mathrm{g}$ & $5-10 \mathrm{~cm}$ & 2003-2010 & Control & 4.06 & 4.22 & $-0.18-9.36$ \\
\hline $\mathrm{Fe}^{3+}$ & $\mu \mathrm{molc} / \mathrm{g}$ & $5-10 \mathrm{~cm}$ & 2003-2010 & Limed & 1.47 & 2.36 & $-0.36-5.51$ \\
\hline $\mathrm{Fe}^{3+}$ & $\mu \mathrm{molc} / \mathrm{g}$ & $5-10 \mathrm{~cm}$ & 2010-2015 & Control & -0.35 & 0.39 & $-0.61-0.33$ \\
\hline $\mathrm{Fe}^{3+}$ & $\mu \mathrm{molc} / \mathrm{g}$ & $5-10 \mathrm{~cm}$ & 2010-2015 & Limed & -0.49 & 0.61 & $-0.85-0.58$ \\
\hline $\mathrm{Fe}^{3+}$ & $\mu \mathrm{molc} / \mathrm{g}$ & $10-30 \mathrm{~cm}$ & 2003-2010 & Control & 5.71 & 10.38 & $-0.34-23.98$ \\
\hline $\mathrm{Fe}^{3+}$ & $\mu \mathrm{molc} / \mathrm{g}$ & $10-30 \mathrm{~cm}$ & 2003-2010 & Limed & 1.66 & 1.51 & $-0.01-3.93$ \\
\hline
\end{tabular}


Table A3. Cont.

\begin{tabular}{|c|c|c|c|c|c|c|c|}
\hline Parameter & Unit & Depth & Period & Treatment & RR Mean & RR SD & RR Range \\
\hline $\mathrm{Fe}^{3+}$ & $\mu \mathrm{molc} / \mathrm{g}$ & $10-30 \mathrm{~cm}$ & 2010-2015 & Control & -0.42 & 0.13 & $-0.52--0.26$ \\
\hline $\mathrm{Fe}^{3+}$ & $\mu \mathrm{molc} / \mathrm{g}$ & $10-30 \mathrm{~cm}$ & 2010-2015 & Limed & -0.41 & 0.59 & $-0.91-0.59$ \\
\hline $\mathrm{Fe}^{3+}$ & $\mu \mathrm{molc} / \mathrm{g}$ & $30-60 \mathrm{~cm}$ & 2003-2010 & Control & 21.11 & 27.42 & $-0.26-67.57$ \\
\hline $\mathrm{Fe}^{3+}$ & $\mu \mathrm{molc} / \mathrm{g}$ & $30-60 \mathrm{~cm}$ & 2003-2010 & Limed & 17.86 & 13.04 & $1.53-37.78$ \\
\hline $\mathrm{Fe}^{3+}$ & $\mu \mathrm{molc} / \mathrm{g}$ & $30-60 \mathrm{~cm}$ & 2010-2015 & Control & -0.66 & 0.28 & $-0.95--0.26$ \\
\hline $\mathrm{Fe}^{3+}$ & $\mu \mathrm{molc} / \mathrm{g}$ & $30-60 \mathrm{~cm}$ & 2010-2015 & Limed & -0.56 & 0.49 & $-0.93-0.28$ \\
\hline $\mathrm{H}^{+}$ & $\mu \mathrm{molc} / \mathrm{g}$ & $0-5 \mathrm{~cm}$ & 2003-2010 & Control & 0.54 & 0.61 & $-0.05-1.44$ \\
\hline $\mathrm{H}^{+}$ & $\mu \mathrm{molc} / \mathrm{g}$ & $0-5 \mathrm{~cm}$ & 2003-2010 & Limed & -0.64 & 0.35 & $-1--0.13$ \\
\hline $\mathrm{H}^{+}$ & $\mu \mathrm{molc} / \mathrm{g}$ & $0-5 \mathrm{~cm}$ & 2010-2015 & Control & 0.07 & 0.33 & $-0.39-0.51$ \\
\hline $\mathrm{H}^{+}$ & $\mu \mathrm{molc} / \mathrm{g}$ & $0-5 \mathrm{~cm}$ & 2010-2015 & Limed & 6.1 & 14.51 & $-0.9-32.04$ \\
\hline $\mathrm{H}^{+}$ & $\mu \mathrm{molc} / \mathrm{g}$ & $5-10 \mathrm{~cm}$ & 2003-2010 & Control & 0.23 & 0.58 & $-0.4-1.05$ \\
\hline $\mathrm{H}^{+}$ & $\mu \mathrm{molc} / \mathrm{g}$ & $5-10 \mathrm{~cm}$ & 2003-2010 & Limed & -0.15 & 0.55 & $-0.62-0.8$ \\
\hline $\mathrm{H}^{+}$ & $\mu \mathrm{molc} / \mathrm{g}$ & $5-10 \mathrm{~cm}$ & 2010-2015 & Control & 0.34 & 0.68 & $-0.26-1.5$ \\
\hline $\mathrm{H}^{+}$ & $\mu \mathrm{molc} / \mathrm{g}$ & $5-10 \mathrm{~cm}$ & 2010-2015 & Limed & -0.05 & 0.79 & $-0.75-1.14$ \\
\hline $\mathrm{H}^{+}$ & $\mu \mathrm{molc} / \mathrm{g}$ & $10-30 \mathrm{~cm}$ & 2003-2010 & Control & -0.28 & 0.63 & $-0.93-0.38$ \\
\hline $\mathrm{H}^{+}$ & $\mu \mathrm{molc} / \mathrm{g}$ & $10-30 \mathrm{~cm}$ & 2003-2010 & Limed & -0.27 & 0.5 & $-0.75-0.49$ \\
\hline $\mathrm{H}^{+}$ & $\mu \mathrm{molc} / \mathrm{g}$ & $10-30 \mathrm{~cm}$ & 2010-2015 & Control & 2.41 & 3.63 & $-0.42-8.15$ \\
\hline $\mathrm{H}^{+}$ & $\mu \mathrm{molc} / \mathrm{g}$ & $10-30 \mathrm{~cm}$ & 2010-2015 & Limed & 1.24 & 2.63 & $-0.35-5.91$ \\
\hline $\mathrm{H}^{+}$ & $\mu \mathrm{molc} / \mathrm{g}$ & $30-60 \mathrm{~cm}$ & 2003-2010 & Control & -0.5 & 0.4 & $-0.96--0.05$ \\
\hline $\mathrm{H}^{+}$ & $\mu \mathrm{molc} / \mathrm{g}$ & $30-60 \mathrm{~cm}$ & 2003-2010 & Limed & 1.16 & 3.69 & $-0.73-7.75$ \\
\hline $\mathrm{H}^{+}$ & $\mu \mathrm{molc} / \mathrm{g}$ & $30-60 \mathrm{~cm}$ & 2010-2015 & Control & 2.76 & 5.44 & $-0.37-12.4$ \\
\hline $\mathrm{H}^{+}$ & $\mu \mathrm{molc} / \mathrm{g}$ & $30-60 \mathrm{~cm}$ & 2010-2015 & Limed & 0.57 & 0.68 & $-0.5-1.07$ \\
\hline K & $\mathrm{g} / \mathrm{kg}$ & O-layer & 2003-2010 & Control & 0.22 & 0.38 & $-0.1-0.86$ \\
\hline $\mathrm{K}$ & $\mathrm{g} / \mathrm{kg}$ & O-layer & 2003-2010 & Limed & 0.13 & 0.23 & $-0.08-0.48$ \\
\hline K & $\mathrm{g} / \mathrm{kg}$ & O-layer & 2010-2015 & Control & 0.07 & 0.21 & $-0.16-0.34$ \\
\hline K & $\mathrm{g} / \mathrm{kg}$ & O-layer & 2010-2015 & Limed & -0.04 & 0.24 & $-0.25-0.34$ \\
\hline $\mathrm{K}^{+}$ & $\mu \mathrm{molc} / \mathrm{g}$ & $0-5 \mathrm{~cm}$ & 2003-2010 & Control & 0.15 & 0.66 & $-0.4-1.18$ \\
\hline $\mathrm{K}^{+}$ & $\mu \mathrm{molc} / \mathrm{g}$ & $0-5 \mathrm{~cm}$ & 2003-2010 & Limed & 0.69 & 0.98 & $-0.19-1.95$ \\
\hline $\mathrm{K}^{+}$ & $\mu \mathrm{molc} / \mathrm{g}$ & $0-5 \mathrm{~cm}$ & 2010-2015 & Control & 0.46 & 0.34 & $-0.02-0.82$ \\
\hline $\mathrm{K}^{+}$ & $\mu \mathrm{molc} / \mathrm{g}$ & $0-5 \mathrm{~cm}$ & 2010-2015 & Limed & 0 & 0.25 & $-0.36-0.29$ \\
\hline $\mathrm{K}^{+}$ & $\mu \mathrm{molc} / \mathrm{g}$ & $5-10 \mathrm{~cm}$ & 2003-2010 & Control & 0.07 & 0.39 & $-0.31-0.68$ \\
\hline $\mathrm{K}^{+}$ & $\mu \mathrm{molc} / \mathrm{g}$ & $5-10 \mathrm{~cm}$ & $2003-2010$ & Limed & 0.27 & 0.45 & $-0.15-0.89$ \\
\hline $\mathrm{K}^{+}$ & $\mu \mathrm{molc} / \mathrm{g}$ & $5-10 \mathrm{~cm}$ & 2010-2015 & Control & 0.26 & 0.44 & $-0.12-1.02$ \\
\hline $\mathrm{K}^{+}$ & $\mu \mathrm{molc} / \mathrm{g}$ & $5-10 \mathrm{~cm}$ & 2010-2015 & Limed & -0.03 & 0.23 & $-0.24-0.34$ \\
\hline $\mathrm{K}^{+}$ & $\mu \mathrm{molc} / \mathrm{g}$ & $10-30 \mathrm{~cm}$ & 2003-2010 & Control & 0.39 & 0.69 & $-0.33-1.1$ \\
\hline $\mathrm{K}^{+}$ & $\mu \mathrm{molc} / \mathrm{g}$ & $10-30 \mathrm{~cm}$ & 2003-2010 & Limed & 0.1 & 0.41 & $-0.34-0.77$ \\
\hline $\mathrm{K}^{+}$ & $\mu \mathrm{molc} / \mathrm{g}$ & $10-30 \mathrm{~cm}$ & 2010-2015 & Control & 0.1 & 0.27 & $-0.17-0.45$ \\
\hline $\mathrm{K}^{+}$ & $\mu \mathrm{molc} / \mathrm{g}$ & $10-30 \mathrm{~cm}$ & 2010-2015 & Limed & 0.04 & 0.14 & $-0.2-0.15$ \\
\hline $\mathrm{K}^{+}$ & $\mu \mathrm{molc} / \mathrm{g}$ & $30-60 \mathrm{~cm}$ & 2003-2010 & Control & 0.53 & 0.95 & $-0.38-1.57$ \\
\hline $\mathrm{K}^{+}$ & $\mu \mathrm{molc} / \mathrm{g}$ & $30-60 \mathrm{~cm}$ & 2003-2010 & Limed & 0.25 & 0.53 & $-0.33-0.93$ \\
\hline $\mathrm{K}^{+}$ & $\mu \mathrm{molc} / \mathrm{g}$ & $30-60 \mathrm{~cm}$ & 2010-2015 & Control & 0.08 & 0.24 & $-0.27-0.32$ \\
\hline $\mathrm{K}^{+}$ & $\mu \mathrm{molc} / \mathrm{g}$ & $30-60 \mathrm{~cm}$ & 2010-2015 & Limed & -0.12 & 0.16 & $-0.2-0.16$ \\
\hline Mn & $\mathrm{g} / \mathrm{kg}$ & O-layer & 2003-2010 & Control & 0.5 & 1.03 & $-0.2-2.26$ \\
\hline $\mathrm{Mn}$ & $\mathrm{g} / \mathrm{kg}$ & O-layer & 2003-2010 & Limed & 1.25 & 0.56 & $0.41-1.85$ \\
\hline Mn & $\mathrm{g} / \mathrm{kg}$ & O-layer & 2010-2015 & Control & 0.62 & 0.56 & $-0.01-1.45$ \\
\hline $\mathrm{Mn}$ & $\mathrm{g} / \mathrm{kg}$ & O-layer & 2010-2015 & Limed & 0.01 & 0.56 & $-0.37-1$ \\
\hline $\mathrm{Mn}^{2+}$ & $\mu \mathrm{molc} / \mathrm{g}$ & $0-5 \mathrm{~cm}$ & 2003-2010 & Control & 1.56 & 1.81 & $-0.21-4.42$ \\
\hline $\mathrm{Mn}^{2+}$ & $\mu \mathrm{molc} / \mathrm{g}$ & $0-5 \mathrm{~cm}$ & 2003-2010 & Limed & 1.3 & 1.84 & $-0.61-4.32$ \\
\hline $\mathrm{Mn}^{2+}$ & $\mu \mathrm{molc} / \mathrm{g}$ & $0-5 \mathrm{~cm}$ & 2010-2015 & Control & 7.57 & 15.79 & $-0.56-35.76$ \\
\hline $\mathrm{Mn}^{2+}$ & $\mu \mathrm{molc} / \mathrm{g}$ & $0-5 \mathrm{~cm}$ & 2010-2015 & Limed & 2.79 & 5.69 & $-0.21-12.95$ \\
\hline $\mathrm{Mn}^{2+}$ & $\mu \mathrm{molc} / \mathrm{g}$ & $5-10 \mathrm{~cm}$ & 2003-2010 & Control & 6.19 & 9.18 & $-0.64-20.46$ \\
\hline $\mathrm{Mn}^{2+}$ & $\mu \mathrm{molc} / \mathrm{g}$ & $5-10 \mathrm{~cm}$ & 2003-2010 & Limed & 0.46 & 0.83 & $-0.56-1.18$ \\
\hline $\mathrm{Mn}^{2+}$ & $\mu \mathrm{molc} / \mathrm{g}$ & $5-10 \mathrm{~cm}$ & 2010-2015 & Control & 1.15 & 3.01 & $-0.52-6.52$ \\
\hline $\mathrm{Mn}^{2+}$ & $\mu \mathrm{molc} / \mathrm{g}$ & $5-10 \mathrm{~cm}$ & 2010-2015 & Limed & 0.84 & 1.81 & $-0.64-3.98$ \\
\hline $\mathrm{Mn}^{2+}$ & $\mu \mathrm{molc} / \mathrm{g}$ & $10-30 \mathrm{~cm}$ & 2003-2010 & Control & 49.57 & 106.0 & $-0.15-239.18$ \\
\hline
\end{tabular}


Table A3. Cont.

\begin{tabular}{|c|c|c|c|c|c|c|c|}
\hline Parameter & Unit & Depth & Period & Treatment & RR Mean & RR SD & RR Range \\
\hline $\mathrm{Mn}^{2+}$ & $\mu \mathrm{molc} / \mathrm{g}$ & $10-30 \mathrm{~cm}$ & 2003-2010 & Limed & 0.54 & 0.31 & $0.14-0.87$ \\
\hline $\mathrm{Mn}^{2+}$ & umolc/g & $10-30 \mathrm{~cm}$ & 2010-2015 & Control & -0.29 & 0.47 & $-0.6-0.55$ \\
\hline $\mathrm{Mn}^{2+}$ & $\mu \mathrm{molc} / \mathrm{g}$ & $10-30 \mathrm{~cm}$ & 2010-2015 & Limed & -0.05 & 0.51 & $-0.51-0.79$ \\
\hline $\mathrm{Mn}^{2+}$ & $\mu \mathrm{molc} / \mathrm{g}$ & $30-60 \mathrm{~cm}$ & $2003-2010$ & Control & 6.07 & 8.7 & $-0.17-21.37$ \\
\hline $\mathrm{Mn}^{2+}$ & $\mu \mathrm{molc} / \mathrm{g}$ & $30-60 \mathrm{~cm}$ & $2003-2010$ & Limed & 1.79 & 1.73 & $0.36-3.92$ \\
\hline $\mathrm{Mn}^{2+}$ & $\mu \mathrm{molc} / \mathrm{g}$ & $30-60 \mathrm{~cm}$ & 2010-2015 & Control & -0.44 & 0.15 & $-0.55--0.22$ \\
\hline $\mathrm{Mn}^{2+}$ & $\mu \mathrm{molc} / \mathrm{g}$ & $30-60 \mathrm{~cm}$ & 2010-2015 & Limed & -0.13 & 0.46 & $-0.68-0.42$ \\
\hline $\mathrm{Na}$ & $\mathrm{g} / \mathrm{kg}$ & O-layer & $2003-2010$ & Control & 0.68 & 0.56 & $0.27-1.65$ \\
\hline $\mathrm{Na}$ & $\mathrm{g} / \mathrm{kg}$ & O-layer & 2003-2010 & Limed & 0.65 & 0.54 & $-0.06-1.33$ \\
\hline $\mathrm{Na}$ & $\mathrm{g} / \mathrm{kg}$ & O-layer & 2010-2015 & Control & -0.16 & 0.31 & $-0.55-0.17$ \\
\hline $\mathrm{Na}$ & $\mathrm{g} / \mathrm{kg}$ & O-layer & 2010-2015 & Limed & -0.05 & 0.68 & $-0.66-0.78$ \\
\hline $\mathrm{Na}^{+}$ & $\mu \mathrm{molc} / \mathrm{g}$ & $0-5 \mathrm{~cm}$ & $2003-2010$ & Control & 2.42 & 1.45 & $1-4.35$ \\
\hline $\mathrm{Na}^{+}$ & $\mu \mathrm{molc} / \mathrm{g}$ & $0-5 \mathrm{~cm}$ & $2003-2010$ & Limed & 2.93 & 4.18 & $-0.06-10.04$ \\
\hline $\mathrm{Na}^{+}$ & $\mu \mathrm{molc} / \mathrm{g}$ & $0-5 \mathrm{~cm}$ & 2010-2015 & Control & 0.52 & 0.9 & $-0.08-2.09$ \\
\hline $\mathrm{Na}^{+}$ & $\mu \mathrm{molc} / \mathrm{g}$ & $0-5 \mathrm{~cm}$ & 2010-2015 & Limed & 0.86 & 0.46 & $0.21-1.21$ \\
\hline $\mathrm{Na}^{+}$ & $\mu \mathrm{molc} / \mathrm{g}$ & $5-10 \mathrm{~cm}$ & 2003-2010 & Control & 1.66 & 0.55 & $1.1-2.5$ \\
\hline $\mathrm{Na}^{+}$ & $\mu \mathrm{molc} / \mathrm{g}$ & $5-10 \mathrm{~cm}$ & 2003-2010 & Limed & 2.58 & 2.4 & $0.42-6.53$ \\
\hline $\mathrm{Na}^{+}$ & $\mu \mathrm{molc} / \mathrm{g}$ & $5-10 \mathrm{~cm}$ & 2010-2015 & Control & 0.25 & 0.48 & $-0.31-0.97$ \\
\hline $\mathrm{Na}^{+}$ & $\mu \mathrm{molc} / \mathrm{g}$ & $5-10 \mathrm{~cm}$ & 2010-2015 & Limed & 0.52 & 0.49 & $-0.03-1.21$ \\
\hline $\mathrm{Na}^{+}$ & $\mu \mathrm{molc} / \mathrm{g}$ & $10-30 \mathrm{~cm}$ & 2003-2010 & Control & 3.39 & 3.3 & $-0.05-7.56$ \\
\hline $\mathrm{Na}^{+}$ & $\mu \mathrm{molc} / \mathrm{g}$ & $10-30 \mathrm{~cm}$ & 2003-2010 & Limed & 2.71 & 4.08 & $0.41-9.95$ \\
\hline $\mathrm{Na}^{+}$ & $\mu \mathrm{molc} / \mathrm{g}$ & $10-30 \mathrm{~cm}$ & 2010-2015 & Control & 0.14 & 0.42 & $-0.27-0.72$ \\
\hline $\mathrm{Na}^{+}$ & $\mu \mathrm{molc} / \mathrm{g}$ & $10-30 \mathrm{~cm}$ & 2010-2015 & Limed & 0.94 & 1.77 & $-0.21-4.08$ \\
\hline $\mathrm{Na}^{+}$ & $\mu \mathrm{molc} / \mathrm{g}$ & $30-60 \mathrm{~cm}$ & 2003-2010 & Control & 1.29 & 2.46 & $-0.38-5.64$ \\
\hline $\mathrm{Na}^{+}$ & $\mu \mathrm{molc} / \mathrm{g}$ & $30-60 \mathrm{~cm}$ & $2003-2010$ & Limed & 4.27 & 5.05 & $0.03-12.48$ \\
\hline $\mathrm{Na}^{+}$ & $\mu \mathrm{molc} / \mathrm{g}$ & $30-60 \mathrm{~cm}$ & 2010-2015 & Control & 0.24 & 0.63 & $-0.33-1.24$ \\
\hline $\mathrm{Na}^{+}$ & $\mu \mathrm{molc} / \mathrm{g}$ & $30-60 \mathrm{~cm}$ & 2010-2015 & Limed & 0.02 & 0.61 & $-0.42-1.08$ \\
\hline $\mathrm{N}_{\text {tot }}$ & $\mathrm{g} / \mathrm{kg}$ & O-layer & $2003-2010$ & Control & 0.07 & 0.24 & $-0.16-0.34$ \\
\hline $\mathrm{N}_{\text {tot }}$ & $\mathrm{g} / \mathrm{kg}$ & O-layer & 2003-2010 & Limed & 0.18 & 0.62 & $-0.33-1.03$ \\
\hline $\mathrm{N}_{\text {tot }}$ & $\mathrm{g} / \mathrm{kg}$ & O-layer & 2010-2015 & Control & -0.12 & 0.07 & $-0.23--0.07$ \\
\hline $\mathrm{N}_{\text {tot }}$ & $\mathrm{g} / \mathrm{kg}$ & O-layer & 2010-2015 & Limed & 0.03 & 0.21 & $-0.25-0.28$ \\
\hline $\mathrm{N}_{\text {tot }}$ & $\mathrm{g} / \mathrm{kg}$ & $0-5 \mathrm{~cm}$ & 2003-2010 & Control & 0.27 & 0.44 & $-0.29-0.89$ \\
\hline $\mathrm{N}_{\text {tot }}$ & $\mathrm{g} / \mathrm{kg}$ & $0-5 \mathrm{~cm}$ & 2003-2010 & Limed & 0.65 & 0.53 & $0.11-1.23$ \\
\hline $\mathrm{N}_{\text {tot }}$ & $\mathrm{g} / \mathrm{kg}$ & $0-5 \mathrm{~cm}$ & 2010-2015 & Control & 0.26 & 0.33 & $-0.14-0.6$ \\
\hline $\mathrm{N}_{\text {tot }}$ & $\mathrm{g} / \mathrm{kg}$ & $0-5 \mathrm{~cm}$ & 2010-2015 & Limed & 0.16 & 0.31 & $-0.1-0.66$ \\
\hline $\mathrm{N}_{\text {tot }}$ & $\mathrm{g} / \mathrm{kg}$ & $5-10 \mathrm{~cm}$ & 2003-2010 & Control & 0.17 & 0.38 & $-0.14-0.8$ \\
\hline $\mathrm{N}_{\text {tot }}$ & $\mathrm{g} / \mathrm{kg}$ & $5-10 \mathrm{~cm}$ & 2003-2010 & Limed & 0.17 & 0.2 & $-0.05-0.35$ \\
\hline $\mathrm{N}_{\text {tot }}$ & $\mathrm{g} / \mathrm{kg}$ & $5-10 \mathrm{~cm}$ & 2010-2015 & Control & 0.22 & 0.44 & $-0.21-0.95$ \\
\hline $\mathrm{N}_{\text {tot }}$ & $\mathrm{g} / \mathrm{kg}$ & $5-10 \mathrm{~cm}$ & 2010-2015 & Limed & 0.24 & 0.25 & $-0.03-0.62$ \\
\hline $\mathrm{N}_{\text {tot }}$ & $\mathrm{g} / \mathrm{kg}$ & $10-30 \mathrm{~cm}$ & 2003-2010 & Control & 0.35 & 0.71 & $-0.11-1.61$ \\
\hline $\mathrm{N}_{\text {tot }}$ & $\mathrm{g} / \mathrm{kg}$ & $10-30 \mathrm{~cm}$ & 2003-2010 & Limed & 0 & 0.18 & $-0.29-0.16$ \\
\hline $\mathrm{N}_{\text {tot }}$ & $\mathrm{g} / \mathrm{kg}$ & $10-30 \mathrm{~cm}$ & 2010-2015 & Control & -0.01 & 0.16 & $-0.12-0.25$ \\
\hline $\mathrm{N}_{\text {tot }}$ & $\mathrm{g} / \mathrm{kg}$ & $10-30 \mathrm{~cm}$ & 2010-2015 & Limed & 0.09 & 0.22 & $-0.2-0.39$ \\
\hline $\mathrm{N}_{\text {tot }}$ & $\mathrm{g} / \mathrm{kg}$ & $30-60 \mathrm{~cm}$ & 2003-2010 & Control & 0.76 & 1.27 & $-0.06-2.89$ \\
\hline $\mathrm{N}_{\text {tot }}$ & $\mathrm{g} / \mathrm{kg}$ & $30-60 \mathrm{~cm}$ & 2003-2010 & Limed & -0.01 & 0.27 & $-0.39-0.31$ \\
\hline $\mathrm{N}_{\text {tot }}$ & $\mathrm{g} / \mathrm{kg}$ & $30-60 \mathrm{~cm}$ & 2010-2015 & Control & -0.05 & 0.12 & $-0.18-0.13$ \\
\hline $\mathrm{N}_{\text {tot }}$ & $\mathrm{g} / \mathrm{kg}$ & $30-60 \mathrm{~cm}$ & 2010-2015 & Limed & 0.13 & 0.23 & $-0.13-0.45$ \\
\hline $\mathrm{pH}-\mathrm{KCl}$ & & O-layer & 2003-2010 & Control & 0.03 & 0.25 & $-0.31-0.31$ \\
\hline $\mathrm{pH}-\mathrm{KCl}$ & & O-layer & 2003-2010 & Limed & 2.46 & 0.53 & $1.54-2.85$ \\
\hline $\mathrm{pH}-\mathrm{KCl}$ & & O-layer & 2010-2015 & Control & 0.29 & 0.22 & $0.08-0.65$ \\
\hline $\mathrm{pH}-\mathrm{KCl}$ & & O-layer & 2010-2015 & Limed & -1.09 & 0.59 & $-1.67--0.11$ \\
\hline $\mathrm{pH}-\mathrm{KCl}$ & & $0-5 \mathrm{~cm}$ & 2003-2010 & Control & 0.08 & 0.13 & $-0.15-0.19$ \\
\hline $\mathrm{pH}-\mathrm{KCl}$ & & $0-5 \mathrm{~cm}$ & 2003-2010 & Limed & 1.11 & 0.73 & $0.57-2.25$ \\
\hline $\mathrm{pH}-\mathrm{KCl}$ & & $0-5 \mathrm{~cm}$ & 2010-2015 & Control & -0.01 & 0.16 & $-0.18-0.17$ \\
\hline $\mathrm{pH}-\mathrm{KCl}$ & & $0-5 \mathrm{~cm}$ & 2010-2015 & Limed & -0.1 & 0.74 & $-1.06-0.99$ \\
\hline $\mathrm{pH}-\mathrm{KCl}$ & & $5-10 \mathrm{~cm}$ & 2003-2010 & Control & 0.09 & 0.13 & $-0.13-0.22$ \\
\hline
\end{tabular}


Table A3. Cont.

\begin{tabular}{|c|c|c|c|c|c|c|c|}
\hline Parameter & Unit & Depth & Period & Treatment & RR Mean & RR SD & RR Range \\
\hline $\mathrm{pH}-\mathrm{KCl}$ & & $5-10 \mathrm{~cm}$ & 2003-2010 & Limed & 0.28 & 0.24 & $-0.06-0.59$ \\
\hline $\mathrm{pH}-\mathrm{KCl}$ & & $5-10 \mathrm{~cm}$ & 2010-2015 & Control & -0.08 & 0.16 & $-0.34-0.06$ \\
\hline $\mathrm{pH}-\mathrm{KCl}$ & & $5-10 \mathrm{~cm}$ & 2010-2015 & Limed & 0.17 & 0.4 & $-0.32-0.65$ \\
\hline $\mathrm{pH}-\mathrm{KCl}$ & & $10-30 \mathrm{~cm}$ & 2003-2010 & Control & 0.16 & 0.13 & $-0.01-0.29$ \\
\hline $\mathrm{pH}-\mathrm{KCl}$ & & $10-30 \mathrm{~cm}$ & 2003-2010 & Limed & 0.15 & 0.11 & $-0.01-0.25$ \\
\hline $\mathrm{pH}-\mathrm{KCl}$ & & $10-30 \mathrm{~cm}$ & 2010-2015 & Control & -0.04 & 0.17 & $-0.23-0.19$ \\
\hline $\mathrm{pH}-\mathrm{KCl}$ & & $10-30 \mathrm{~cm}$ & 2010-2015 & Limed & -0.07 & 0.17 & $-0.34-0.1$ \\
\hline $\mathrm{pH}-\mathrm{KCl}$ & & $30-60 \mathrm{~cm}$ & $2003-2010$ & Control & 0.15 & 0.2 & $-0.02-0.49$ \\
\hline $\mathrm{pH}-\mathrm{KCl}$ & & $30-60 \mathrm{~cm}$ & 2003-2010 & Limed & 0.07 & 0.17 & $-0.22-0.24$ \\
\hline $\mathrm{pH}-\mathrm{KCl}$ & & $30-60 \mathrm{~cm}$ & 2010-2015 & Control & -0.07 & 0.2 & $-0.3-0.14$ \\
\hline $\mathrm{pH}-\mathrm{KCl}$ & & $30-60 \mathrm{~cm}$ & 2010-2015 & Limed & -0.01 & 0.09 & $-0.07-0.15$ \\
\hline
\end{tabular}

Table A4. G2 study site parameter $\mathrm{pH}-\mathrm{KCl}, \mathrm{Mg}, \mathrm{K}, \mathrm{Na}, \mathrm{Fe}, \mathrm{Mn}, \mathrm{H}, \mathrm{C}$ and $\mathrm{N}$ response ratios (RR) to time in 2003-2015.

\begin{tabular}{|c|c|c|c|c|c|c|c|}
\hline Parameter & Unit & Depth & Period & Treatment & RR Mean & RR SD & RR Range \\
\hline $\mathrm{C} / \mathrm{N}$ & & O-layer & 2003-2010 & Control & -0.13 & 1.53 & $-2.04-1.86$ \\
\hline $\mathrm{C} / \mathrm{N}$ & & O-layer & 2003-2010 & Limed & -2.5 & 3.54 & $-7.1-2.02$ \\
\hline $\mathrm{C} / \mathrm{N}$ & & O-layer & 2010-2015 & Control & -1.25 & 1.02 & $-2.44-0.34$ \\
\hline $\mathrm{C} / \mathrm{N}$ & & O-layer & 2010-2015 & Limed & 0.07 & 1.7 & $-2.51-2.2$ \\
\hline $\mathrm{C} / \mathrm{N}$ & & $0-5 \mathrm{~cm}$ & 2003-2010 & Control & 0.3 & 1.63 & $-1.03-2.98$ \\
\hline $\mathrm{C} / \mathrm{N}$ & & $0-5 \mathrm{~cm}$ & 2003-2010 & Limed & -0.3 & 2.24 & $-2.7-3.38$ \\
\hline $\mathrm{C} / \mathrm{N}$ & & $0-5 \mathrm{~cm}$ & 2010-2015 & Control & -1.68 & 3.39 & $-6.88-2.45$ \\
\hline $\mathrm{C} / \mathrm{N}$ & & $0-5 \mathrm{~cm}$ & 2010-2015 & Limed & -0.09 & 1.99 & $-3.11-2.32$ \\
\hline $\mathrm{C} / \mathrm{N}$ & & $5-10 \mathrm{~cm}$ & 2003-2010 & Control & -0.08 & 1.21 & $-1.05-1.85$ \\
\hline $\mathrm{C} / \mathrm{N}$ & & $5-10 \mathrm{~cm}$ & 2003-2010 & Limed & -0.63 & 2.28 & $-3.67-1.93$ \\
\hline $\mathrm{C} / \mathrm{N}$ & & $5-10 \mathrm{~cm}$ & 2010-2015 & Control & -1.02 & 2.92 & $-5.69-2.3$ \\
\hline $\mathrm{C} / \mathrm{N}$ & & $5-10 \mathrm{~cm}$ & 2010-2015 & Limed & 0.06 & 1.8 & $-1.62-2.78$ \\
\hline $\mathrm{C} / \mathrm{N}$ & & $10-30 \mathrm{~cm}$ & 2003-2010 & Control & -0.89 & 1.91 & $-3.28-1.88$ \\
\hline $\mathrm{C} / \mathrm{N}$ & & $10-30 \mathrm{~cm}$ & 2003-2010 & Limed & -0.1 & 2.12 & $-2.98-1.97$ \\
\hline $\mathrm{C} / \mathrm{N}$ & & $10-30 \mathrm{~cm}$ & 2010-2015 & Control & -0.53 & 1.85 & $-3.68-1.13$ \\
\hline $\mathrm{C} / \mathrm{N}$ & & $10-30 \mathrm{~cm}$ & 2010-2015 & Limed & -0.24 & 0.54 & $-0.91-0.48$ \\
\hline $\mathrm{C} / \mathrm{N}$ & & $30-60 \mathrm{~cm}$ & 2003-2010 & Control & -1.29 & 2.97 & $-5.17-1.78$ \\
\hline $\mathrm{C} / \mathrm{N}$ & & $30-60 \mathrm{~cm}$ & 2003-2010 & Limed & -0.48 & 1.64 & $-2.9-0.97$ \\
\hline $\mathrm{C} / \mathrm{N}$ & & $30-60 \mathrm{~cm}$ & 2010-2015 & Control & 0.51 & 1.55 & $-1.33-2.17$ \\
\hline $\mathrm{C} / \mathrm{N}$ & & $30-60 \mathrm{~cm}$ & 2010-2015 & Limed & -0.23 & 1.12 & $-2.09-0.82$ \\
\hline $\mathrm{C}_{\mathrm{tot}}$ & $\mathrm{g} / \mathrm{kg}$ & O-layer & 2003-2010 & Control & -0.1 & 0.11 & $-0.28-0$ \\
\hline $\mathrm{C}_{\text {tot }}$ & $\mathrm{g} / \mathrm{kg}$ & O-layer & 2003-2010 & Limed & -0.16 & 0.25 & $-0.42-0.21$ \\
\hline $\mathrm{C}_{\text {tot }}$ & $\mathrm{g} / \mathrm{kg}$ & O-layer & 2010-2015 & Control & -0.04 & 0.28 & $-0.33-0.41$ \\
\hline $\mathrm{C}_{\text {tot }}$ & $\mathrm{g} / \mathrm{kg}$ & O-layer & 2010-2015 & Limed & -0.01 & 0.2 & $-0.25-0.29$ \\
\hline $\mathrm{C}_{\text {tot }}$ & $\mathrm{g} / \mathrm{kg}$ & $0-5 \mathrm{~cm}$ & 2003-2010 & Control & 0.11 & 0.27 & $-0.19-0.47$ \\
\hline $\mathrm{C}_{\text {tot }}$ & $\mathrm{g} / \mathrm{kg}$ & $0-5 \mathrm{~cm}$ & 2003-2010 & Limed & -0.34 & 0.24 & $-0.71--0.04$ \\
\hline $\mathrm{C}_{\text {tot }}$ & $\mathrm{g} / \mathrm{kg}$ & $0-5 \mathrm{~cm}$ & 2010-2015 & Control & 0.3 & 0.66 & $-0.21-1.42$ \\
\hline $\mathrm{C}_{\text {tot }}$ & $\mathrm{g} / \mathrm{kg}$ & $0-5 \mathrm{~cm}$ & 2010-2015 & Limed & 0.31 & 0.2 & $-0.01-0.5$ \\
\hline $\mathrm{C}_{\text {tot }}$ & $\mathrm{g} / \mathrm{kg}$ & $5-10 \mathrm{~cm}$ & 2003-2010 & Control & 0 & 0.15 & $-0.18-0.24$ \\
\hline $\mathrm{C}_{\text {tot }}$ & $\mathrm{g} / \mathrm{kg}$ & $5-10 \mathrm{~cm}$ & 2003-2010 & Limed & -0.04 & 0.34 & $-0.41-0.44$ \\
\hline $\mathrm{C}_{\text {tot }}$ & $\mathrm{g} / \mathrm{kg}$ & $5-10 \mathrm{~cm}$ & 2010-2015 & Control & 0.2 & 0.37 & $-0.18-0.74$ \\
\hline $\mathrm{C}_{\text {tot }}$ & $\mathrm{g} / \mathrm{kg}$ & $5-10 \mathrm{~cm}$ & 2010-2015 & Limed & 0.08 & 0.17 & $-0.08-0.34$ \\
\hline $\mathrm{C}_{\text {tot }}$ & $\mathrm{g} / \mathrm{kg}$ & $10-30 \mathrm{~cm}$ & 2003-2010 & Control & -0.12 & 0.27 & $-0.42-0.19$ \\
\hline $\mathrm{C}_{\text {tot }}$ & $\mathrm{g} / \mathrm{kg}$ & $10-30 \mathrm{~cm}$ & 2003-2010 & Limed & 0.13 & 0.4 & $-0.24-0.76$ \\
\hline $\mathrm{C}_{\text {tot }}$ & $\mathrm{g} / \mathrm{kg}$ & $10-30 \mathrm{~cm}$ & 2010-2015 & Control & 0.2 & 0.24 & $-0.05-0.6$ \\
\hline $\mathrm{C}_{\text {tot }}$ & $\mathrm{g} / \mathrm{kg}$ & $10-30 \mathrm{~cm}$ & 2010-2015 & Limed & 0 & 0.25 & $-0.35-0.26$ \\
\hline$C_{\text {tot }}$ & $\mathrm{g} / \mathrm{kg}$ & $30-60 \mathrm{~cm}$ & 2003-2010 & Control & -0.01 & 0.39 & $-0.54-0.54$ \\
\hline $\mathrm{C}_{\text {tot }}$ & $\mathrm{g} / \mathrm{kg}$ & $30-60 \mathrm{~cm}$ & 2003-2010 & Limed & 0 & 0.27 & $-0.39-0.29$ \\
\hline $\mathrm{C}_{\text {tot }}$ & $\mathrm{g} / \mathrm{kg}$ & $30-60 \mathrm{~cm}$ & 2010-2015 & Control & 0.31 & 0.49 & $-0.07-1.16$ \\
\hline $\mathrm{C}_{\text {tot }}$ & $\mathrm{g} / \mathrm{kg}$ & $30-60 \mathrm{~cm}$ & 2010-2015 & Limed & 0.03 & 0.24 & $-0.36-0.2$ \\
\hline
\end{tabular}


Table A4. Cont.

\begin{tabular}{|c|c|c|c|c|c|c|c|}
\hline Parameter & Unit & Depth & Period & Treatment & RR Mean & RR SD & RR Range \\
\hline $\mathrm{Fe}$ & $\mathrm{g} / \mathrm{kg}$ & O-layer & 2003-2010 & Control & 0.37 & 0.25 & $0.07-0.64$ \\
\hline $\mathrm{Fe}$ & $\mathrm{g} / \mathrm{kg}$ & O-layer & 2003-2010 & Limed & 0.73 & 1.03 & $-0.59-2.04$ \\
\hline $\mathrm{Fe}$ & $\mathrm{g} / \mathrm{kg}$ & O-layer & 2010-2015 & Control & 0.2 & 0.62 & $-0.54-1.06$ \\
\hline $\mathrm{Fe}$ & $\mathrm{g} / \mathrm{kg}$ & O-layer & 2010-2015 & Limed & 0.17 & 0.52 & $-0.32-1$ \\
\hline $\mathrm{Fe}^{3+}$ & $\mu \mathrm{molc} / \mathrm{g}$ & $0-5 \mathrm{~cm}$ & 2003-2010 & Control & 0.88 & 1.49 & $-0.23-3.49$ \\
\hline $\mathrm{Fe}^{3+}$ & $\mu \mathrm{molc} / \mathrm{g}$ & $0-5 \mathrm{~cm}$ & 2003-2010 & Limed & -0.36 & 0.33 & $-0.92--0.11$ \\
\hline $\mathrm{Fe}^{3+}$ & $\mu \mathrm{molc} / \mathrm{g}$ & $0-5 \mathrm{~cm}$ & 2010-2015 & Control & -0.18 & 0.56 & $-0.61-0.78$ \\
\hline $\mathrm{Fe}^{3+}$ & $\mu \mathrm{molc} / \mathrm{g}$ & $0-5 \mathrm{~cm}$ & 2010-2015 & Limed & -0.5 & 0.3 & $-0.72-0.01$ \\
\hline $\mathrm{Fe}^{3+}$ & $\mu \mathrm{molc} / \mathrm{g}$ & $5-10 \mathrm{~cm}$ & 2003-2010 & Control & 2.22 & 3.89 & $-0.64-9.05$ \\
\hline $\mathrm{Fe}^{3+}$ & $\mu \mathrm{molc} / \mathrm{g}$ & $5-10 \mathrm{~cm}$ & 2003-2010 & Limed & 1.16 & 2.59 & $-0.77-4.9$ \\
\hline $\mathrm{Fe}^{3+}$ & $\mu \mathrm{molc} / \mathrm{g}$ & $5-10 \mathrm{~cm}$ & 2010-2015 & Control & -0.01 & 0.97 & $-0.87-1.53$ \\
\hline $\mathrm{Fe}^{3+}$ & $\mu \mathrm{molc} / \mathrm{g}$ & $5-10 \mathrm{~cm}$ & 2010-2015 & Limed & -0.62 & 0.16 & $-0.82--0.45$ \\
\hline $\mathrm{Fe}^{3+}$ & $\mu \mathrm{molc} / \mathrm{g}$ & $10-30 \mathrm{~cm}$ & 2003-2010 & Control & 5.43 & 7.77 & $-0.38-16.3$ \\
\hline $\mathrm{Fe}^{3+}$ & $\mu \mathrm{molc} / \mathrm{g}$ & $10-30 \mathrm{~cm}$ & 2003-2010 & Limed & 5.31 & 7.67 & $0.19-18.7$ \\
\hline $\mathrm{Fe}^{3+}$ & $\mu \mathrm{molc} / \mathrm{g}$ & $10-30 \mathrm{~cm}$ & 2010-2015 & Control & -0.38 & 0.46 & $-0.8-0.38$ \\
\hline $\mathrm{Fe}^{3+}$ & $\mu \mathrm{molc} / \mathrm{g}$ & $10-30 \mathrm{~cm}$ & 2010-2015 & Limed & -0.67 & 0.21 & $-0.86--0.33$ \\
\hline $\mathrm{Fe}^{3+}$ & $\mu \mathrm{molc} / \mathrm{g}$ & $30-60 \mathrm{~cm}$ & 2003-2010 & Control & 8.69 & 5.22 & $1.55-15.6$ \\
\hline $\mathrm{Fe}^{3+}$ & $\mu \mathrm{molc} / \mathrm{g}$ & $30-60 \mathrm{~cm}$ & 2003-2010 & Limed & 12.46 & 11.42 & $3.06-31.27$ \\
\hline $\mathrm{Fe}^{3+}$ & $\mu \mathrm{molc} / \mathrm{g}$ & $30-60 \mathrm{~cm}$ & 2010-2015 & Control & -0.73 & 0.12 & $-0.91--0.61$ \\
\hline $\mathrm{Fe}^{3+}$ & $\mu \mathrm{molc} / \mathrm{g}$ & $30-60 \mathrm{~cm}$ & 2010-2015 & Limed & -0.76 & 0.13 & $-0.93--0.61$ \\
\hline $\mathrm{H}^{+}$ & $\mu \mathrm{molc} / \mathrm{g}$ & $0-5 \mathrm{~cm}$ & 2003-2010 & Control & 0.31 & 0.46 & $-0.17-1.05$ \\
\hline $\mathrm{H}^{+}$ & $\mu \mathrm{molc} / \mathrm{g}$ & $0-5 \mathrm{~cm}$ & 2003-2010 & Limed & -0.65 & 0.26 & $-0.94--0.36$ \\
\hline $\mathrm{H}^{+}$ & $\mu \mathrm{molc} / \mathrm{g}$ & $0-5 \mathrm{~cm}$ & $2010-2015$ & Control & 0.24 & 0.62 & $-0.34-1.23$ \\
\hline $\mathrm{H}^{+}$ & $\mu \mathrm{molc} / \mathrm{g}$ & $0-5 \mathrm{~cm}$ & 2010-2015 & Limed & 0.33 & 0.95 & $-0.44-1.62$ \\
\hline $\mathrm{H}^{+}$ & $\mu \mathrm{molc} / \mathrm{g}$ & $5-10 \mathrm{~cm}$ & $2003-2010$ & Control & -0.1 & 0.55 & $-0.54-0.85$ \\
\hline $\mathrm{H}^{+}$ & $\mu \mathrm{molc} / \mathrm{g}$ & $5-10 \mathrm{~cm}$ & 2003-2010 & Limed & -0.45 & 0.4 & $-0.83-0.1$ \\
\hline $\mathrm{H}^{+}$ & $\mu \mathrm{molc} / \mathrm{g}$ & $5-10 \mathrm{~cm}$ & 2010-2015 & Control & 0.44 & 0.72 & $-0.33-1.54$ \\
\hline $\mathrm{H}^{+}$ & $\mu \mathrm{molc} / \mathrm{g}$ & $5-10 \mathrm{~cm}$ & 2010-2015 & Limed & 0.06 & 0.2 & $-0.09-0.41$ \\
\hline $\mathrm{H}^{+}$ & $\mu \mathrm{molc} / \mathrm{g}$ & $10-30 \mathrm{~cm}$ & 2003-2010 & Control & -0.51 & 0.23 & $-0.72--0.26$ \\
\hline $\mathrm{H}^{+}$ & $\mu \mathrm{molc} / \mathrm{g}$ & $10-30 \mathrm{~cm}$ & 2003-2010 & Limed & -0.4 & 0.14 & $-0.55--0.19$ \\
\hline $\mathrm{H}^{+}$ & $\mu \mathrm{molc} / \mathrm{g}$ & $10-30 \mathrm{~cm}$ & 2010-2015 & Control & 0.48 & 0.34 & $-0.06-0.77$ \\
\hline $\mathrm{H}^{+}$ & $\mu \mathrm{molc} / \mathrm{g}$ & $10-30 \mathrm{~cm}$ & 2010-2015 & Limed & 0.22 & 0.43 & $-0.39-0.71$ \\
\hline $\mathrm{H}^{+}$ & $\mu \mathrm{molc} / \mathrm{g}$ & $30-60 \mathrm{~cm}$ & 2003-2010 & Control & -0.27 & 0.38 & $-0.62-0.37$ \\
\hline $\mathrm{H}^{+}$ & $\mu \mathrm{molc} / \mathrm{g}$ & $30-60 \mathrm{~cm}$ & 2003-2010 & Limed & -0.24 & 0.37 & $-0.6-0.35$ \\
\hline $\mathrm{H}^{+}$ & $\mu \mathrm{molc} / \mathrm{g}$ & $30-60 \mathrm{~cm}$ & 2010-2015 & Control & -0.01 & 0.57 & $-0.87-0.53$ \\
\hline $\mathrm{H}^{+}$ & $\mu \mathrm{molc} / \mathrm{g}$ & $30-60 \mathrm{~cm}$ & 2010-2015 & Limed & 0.09 & 0.6 & $-0.47-0.96$ \\
\hline $\mathrm{K}$ & $\mathrm{g} / \mathrm{kg}$ & O-layer & 2003-2010 & Control & 0.22 & 0.21 & $-0.06-0.47$ \\
\hline K & $\mathrm{g} / \mathrm{kg}$ & O-layer & 2003-2010 & Limed & 0.19 & 0.25 & $-0.25-0.37$ \\
\hline K & $\mathrm{g} / \mathrm{kg}$ & O-layer & 2010-2015 & Control & -0.15 & 0.2 & $-0.44-0.12$ \\
\hline $\mathrm{K}$ & $\mathrm{g} / \mathrm{kg}$ & O-layer & 2010-2015 & Limed & -0.16 & 0.19 & $-0.32-0.16$ \\
\hline $\mathrm{K}^{+}$ & $\mu$ molc/g & $0-5 \mathrm{~cm}$ & 2003-2010 & Control & 0.48 & 0.55 & $-0.41-1.09$ \\
\hline $\mathrm{K}^{+}$ & $\mu \mathrm{molc} / \mathrm{g}$ & $0-5 \mathrm{~cm}$ & 2003-2010 & Limed & 0.04 & 0.21 & $-0.16-0.37$ \\
\hline $\mathrm{K}^{+}$ & $\mu \mathrm{molc} / \mathrm{g}$ & $0-5 \mathrm{~cm}$ & 2010-2015 & Control & 0.33 & 0.48 & $-0.18-1.08$ \\
\hline $\mathrm{K}^{+}$ & $\mu \mathrm{molc} / \mathrm{g}$ & $0-5 \mathrm{~cm}$ & 2010-2015 & Limed & 0.29 & 0.63 & $-0.21-1.28$ \\
\hline $\mathrm{K}^{+}$ & $\mu \mathrm{molc} / \mathrm{g}$ & $5-10 \mathrm{~cm}$ & 2003-2010 & Control & 0.15 & 0.5 & $-0.32-0.92$ \\
\hline $\mathrm{K}^{+}$ & $\mu \mathrm{molc} / \mathrm{g}$ & $5-10 \mathrm{~cm}$ & 2003-2010 & Limed & 0.33 & 0.21 & $0.1-0.53$ \\
\hline $\mathrm{K}^{+}$ & $\mu \mathrm{molc} / \mathrm{g}$ & $5-10 \mathrm{~cm}$ & 2010-2015 & Control & 0.22 & 0.27 & $-0.04-0.67$ \\
\hline $\mathrm{K}^{+}$ & $\mu \mathrm{molc} / \mathrm{g}$ & $5-10 \mathrm{~cm}$ & 2010-2015 & Limed & -0.04 & 0.28 & $-0.4-0.24$ \\
\hline $\mathrm{K}^{+}$ & $\mu \mathrm{molc} / \mathrm{g}$ & $10-30 \mathrm{~cm}$ & 2003-2010 & Control & 0.27 & 0.26 & $-0.01-0.68$ \\
\hline $\mathrm{K}^{+}$ & $\mu \mathrm{molc} / \mathrm{g}$ & $10-30 \mathrm{~cm}$ & 2003-2010 & Limed & 0.35 & 0.31 & $0.11-0.85$ \\
\hline $\mathrm{K}^{+}$ & $\mu \mathrm{molc} / \mathrm{g}$ & $10-30 \mathrm{~cm}$ & 2010-2015 & Control & 0.01 & 0.09 & $-0.11-0.13$ \\
\hline $\mathrm{K}^{+}$ & $\mu \mathrm{molc} / \mathrm{g}$ & $10-30 \mathrm{~cm}$ & 2010-2015 & Limed & -0.05 & 0.13 & $-0.25-0.06$ \\
\hline $\mathrm{K}^{+}$ & $\mu \mathrm{molc} / \mathrm{g}$ & $30-60 \mathrm{~cm}$ & 2003-2010 & Control & 0.18 & 0.22 & $-0.11-0.38$ \\
\hline $\mathrm{K}^{+}$ & $\mu \mathrm{molc} / \mathrm{g}$ & $30-60 \mathrm{~cm}$ & 2003-2010 & Limed & 0.39 & 0.44 & $-0.01-1.11$ \\
\hline $\mathrm{K}^{+}$ & $\mu \mathrm{molc} / \mathrm{g}$ & $30-60 \mathrm{~cm}$ & 2010-2015 & Control & -0.17 & 0.13 & $-0.34--0.01$ \\
\hline $\mathrm{K}^{+}$ & $\mu \mathrm{molc} / \mathrm{g}$ & $30-60 \mathrm{~cm}$ & 2010-2015 & Limed & -0.15 & 0.18 & $-0.46--0.02$ \\
\hline
\end{tabular}


Table A4. Cont.

\begin{tabular}{|c|c|c|c|c|c|c|c|}
\hline Parameter & Unit & Depth & Period & Treatment & RR Mean & RR SD & RR Range \\
\hline Mn & $\mathrm{g} / \mathrm{kg}$ & O-layer & 2003-2010 & Control & 0.99 & 1.36 & $0.06-3.25$ \\
\hline $\mathrm{Mn}$ & $\mathrm{g} / \mathrm{kg}$ & O-layer & 2003-2010 & Limed & 2 & 3.79 & $-0.2-8.75$ \\
\hline $\mathrm{Mn}$ & $\mathrm{g} / \mathrm{kg}$ & O-layer & 2010-2015 & Control & -0.01 & 0.33 & $-0.35-0.38$ \\
\hline $\mathrm{Mn}$ & $\mathrm{g} / \mathrm{kg}$ & O-layer & 2010-2015 & Limed & 0.06 & 0.32 & $-0.33-0.41$ \\
\hline $\mathrm{Mn}^{2+}$ & $\mu \mathrm{molc} / \mathrm{g}$ & $0-5 \mathrm{~cm}$ & $2003-2010$ & Control & 2.59 & 5.64 & $-0.56-12.62$ \\
\hline $\mathrm{Mn}^{2+}$ & $\mu \mathrm{molc} / \mathrm{g}$ & $0-5 \mathrm{~cm}$ & 2003-2010 & Limed & 3.39 & 7.8 & $-0.54-17.32$ \\
\hline $\mathrm{Mn}^{2+}$ & $\mu \mathrm{molc} / \mathrm{g}$ & $0-5 \mathrm{~cm}$ & 2010-2015 & Control & 0.14 & 0.78 & $-0.43-1.49$ \\
\hline $\mathrm{Mn}^{2+}$ & $\mu \mathrm{molc} / \mathrm{g}$ & $0-5 \mathrm{~cm}$ & 2010-2015 & Limed & 0.37 & 0.38 & $-0.16-0.77$ \\
\hline $\mathrm{Mn}^{2+}$ & $\mu \mathrm{molc} / \mathrm{g}$ & $5-10 \mathrm{~cm}$ & 2003-2010 & Control & 2.07 & 4.77 & $-0.4-10.59$ \\
\hline $\mathrm{Mn}^{2+}$ & $\mu \mathrm{molc} / \mathrm{g}$ & $5-10 \mathrm{~cm}$ & $2003-2010$ & Limed & 0.53 & 0.6 & $-0.51-0.94$ \\
\hline $\mathrm{Mn}^{2+}$ & $\mu \mathrm{molc} / \mathrm{g}$ & $5-10 \mathrm{~cm}$ & 2010-2015 & Control & -0.35 & 0.06 & $-0.43--0.28$ \\
\hline $\mathrm{Mn}^{2+}$ & $\mu \mathrm{molc} / \mathrm{g}$ & $5-10 \mathrm{~cm}$ & 2010-2015 & Limed & -0.16 & 0.23 & $-0.47-0.13$ \\
\hline $\mathrm{Mn}^{2+}$ & $\mu \mathrm{molc} / \mathrm{g}$ & $10-30 \mathrm{~cm}$ & 2003-2010 & Control & 0.73 & 1.7 & $-0.58-3.67$ \\
\hline $\mathrm{Mn}^{2+}$ & $\mu \mathrm{molc} / \mathrm{g}$ & $10-30 \mathrm{~cm}$ & 2003-2010 & Limed & 0.48 & 0.79 & $-0.3-1.71$ \\
\hline $\mathrm{Mn}^{2+}$ & $\mu \mathrm{molc} / \mathrm{g}$ & $10-30 \mathrm{~cm}$ & 2010-2015 & Control & -0.28 & 0.25 & $-0.47-0.15$ \\
\hline $\mathrm{Mn}^{2+}$ & $\mu \mathrm{molc} / \mathrm{g}$ & $10-30 \mathrm{~cm}$ & 2010-2015 & Limed & -0.23 & 0.22 & $-0.5-0.11$ \\
\hline $\mathrm{Mn}^{2+}$ & $\mu \mathrm{molc} / \mathrm{g}$ & $30-60 \mathrm{~cm}$ & 2003-2010 & Control & 1.02 & 1.49 & $-0.52-3.39$ \\
\hline $\mathrm{Mn}^{2+}$ & $\mu \mathrm{molc} / \mathrm{g}$ & $30-60 \mathrm{~cm}$ & $2003-2010$ & Limed & 1.97 & 2.55 & $-0.3-6.17$ \\
\hline $\mathrm{Mn}^{2+}$ & $\mu \mathrm{molc} / \mathrm{g}$ & $30-60 \mathrm{~cm}$ & 2010-2015 & Control & -0.12 & 0.49 & $-0.56-0.72$ \\
\hline $\mathrm{Mn}^{2+}$ & $\mu \mathrm{molc} / \mathrm{g}$ & $30-60 \mathrm{~cm}$ & 2010-2015 & Limed & -0.38 & 0.18 & $-0.68--0.18$ \\
\hline $\mathrm{Na}$ & $\mathrm{g} / \mathrm{kg}$ & O-layer & 2003-2010 & Control & 2.71 & 5.62 & $-0.44-12.69$ \\
\hline $\mathrm{Na}$ & $\mathrm{g} / \mathrm{kg}$ & O-layer & 2003-2010 & Limed & 1.14 & 0.92 & $-0.38-2.08$ \\
\hline $\mathrm{Na}$ & $\mathrm{g} / \mathrm{kg}$ & O-layer & 2010-2015 & Control & 0.06 & 0.31 & $-0.41-0.35$ \\
\hline $\mathrm{Na}$ & $\mathrm{g} / \mathrm{kg}$ & O-layer & 2010-2015 & Limed & -0.18 & 0.35 & $-0.59-0.33$ \\
\hline $\mathrm{Na}^{+}$ & $\mu \mathrm{molc} / \mathrm{g}$ & $0-5 \mathrm{~cm}$ & 2003-2010 & Control & 3.02 & 5.85 & $-0.12-13.45$ \\
\hline $\mathrm{Na}^{+}$ & $\mu \mathrm{molc} / \mathrm{g}$ & $0-5 \mathrm{~cm}$ & $2003-2010$ & Limed & 1.13 & 1.27 & $-0.26-2.94$ \\
\hline $\mathrm{Na}^{+}$ & $\mu$ molc/g & $0-5 \mathrm{~cm}$ & 2010-2015 & Control & 0.59 & 0.73 & $-0.31-1.56$ \\
\hline $\mathrm{Na}^{+}$ & $\mu \mathrm{molc} / \mathrm{g}$ & $0-5 \mathrm{~cm}$ & 2010-2015 & Limed & 0.54 & 0.5 & $0.02-1.23$ \\
\hline $\mathrm{Na}^{+}$ & $\mu$ molc/g & $5-10 \mathrm{~cm}$ & 2003-2010 & Control & 2.22 & 3.63 & $-0.3-8.51$ \\
\hline $\mathrm{Na}^{+}$ & $\mu \mathrm{molc} / \mathrm{g}$ & $5-10 \mathrm{~cm}$ & 2003-2010 & Limed & 1.25 & 1.62 & $-0.38-3.54$ \\
\hline $\mathrm{Na}^{+}$ & $\mu$ molc/g & $5-10 \mathrm{~cm}$ & 2010-2015 & Control & 0.41 & 0.61 & $-0.24-1.18$ \\
\hline $\mathrm{Na}^{+}$ & $\mu \mathrm{molc} / \mathrm{g}$ & $5-10 \mathrm{~cm}$ & 2010-2015 & Limed & 0.51 & 0.52 & $-0.05-1.18$ \\
\hline $\mathrm{Na}^{+}$ & $\mu$ molc/g & $10-30 \mathrm{~cm}$ & $2003-2010$ & Control & 0.34 & 1.04 & $-0.44-2.1$ \\
\hline $\mathrm{Na}^{+}$ & $\mu$ molc/g & $10-30 \mathrm{~cm}$ & 2003-2010 & Limed & 1.13 & 1.47 & $0.08-3.24$ \\
\hline $\mathrm{Na}^{+}$ & $\mu \mathrm{molc} / \mathrm{g}$ & $10-30 \mathrm{~cm}$ & 2010-2015 & Control & 0.88 & 1.37 & $-0.04-3.3$ \\
\hline $\mathrm{Na}^{+}$ & $\mu$ molc/g & $10-30 \mathrm{~cm}$ & $2010-2015$ & Limed & 0.54 & 0.99 & $-0.49-2.12$ \\
\hline $\mathrm{Na}^{+}$ & $\mu \mathrm{molc} / \mathrm{g}$ & $30-60 \mathrm{~cm}$ & 2003-2010 & Control & 0.15 & 0.41 & $-0.32-0.7$ \\
\hline $\mathrm{Na}^{+}$ & $\mu \mathrm{molc} / \mathrm{g}$ & $30-60 \mathrm{~cm}$ & 2003-2010 & Limed & 2.11 & 2.37 & $-0.38-5.7$ \\
\hline $\mathrm{Na}^{+}$ & $\mu$ molc/g & $30-60 \mathrm{~cm}$ & 2010-2015 & Control & 0 & 0.67 & $-0.55-1.14$ \\
\hline $\mathrm{Na}^{+}$ & $\mu$ molc/g & $30-60 \mathrm{~cm}$ & 2010-2015 & Limed & 0.21 & 0.73 & $-0.48-1.31$ \\
\hline $\mathrm{N}_{\text {tot }}$ & $\mathrm{g} / \mathrm{kg}$ & O-layer & 2003-2010 & Control & -0.09 & 0.15 & $-0.33-0.05$ \\
\hline $\mathrm{N}_{\text {tot }}$ & $\mathrm{g} / \mathrm{kg}$ & O-layer & 2003-2010 & Limed & -0.09 & 0.19 & $-0.25-0.22$ \\
\hline $\mathrm{N}_{\text {tot }}$ & $\mathrm{g} / \mathrm{kg}$ & O-layer & 2010-2015 & Control & 0 & 0.27 & $-0.27-0.46$ \\
\hline $\mathrm{N}_{\text {tot }}$ & $\mathrm{g} / \mathrm{kg}$ & O-layer & 2010-2015 & Limed & -0.01 & 0.14 & $-0.16-0.18$ \\
\hline $\mathrm{N}_{\text {tot }}$ & $\mathrm{g} / \mathrm{kg}$ & $0-5 \mathrm{~cm}$ & 2003-2010 & Control & 0.08 & 0.24 & $-0.16-0.41$ \\
\hline $\mathrm{N}_{\text {tot }}$ & $\mathrm{g} / \mathrm{kg}$ & $0-5 \mathrm{~cm}$ & 2003-2010 & Limed & -0.32 & 0.26 & $-0.69-0.01$ \\
\hline $\mathrm{N}_{\text {tot }}$ & $\mathrm{g} / \mathrm{kg}$ & $0-5 \mathrm{~cm}$ & 2010-2015 & Control & 0.34 & 0.44 & $-0.14-1.02$ \\
\hline $\mathrm{N}_{\text {tot }}$ & $\mathrm{g} / \mathrm{kg}$ & $0-5 \mathrm{~cm}$ & 2010-2015 & Limed & 0.32 & 0.26 & $0.03-0.69$ \\
\hline $\mathrm{N}_{\text {tot }}$ & $\mathrm{g} / \mathrm{kg}$ & $5-10 \mathrm{~cm}$ & 2003-2010 & Control & 0 & 0.12 & $-0.13-0.19$ \\
\hline $\mathrm{N}_{\text {tot }}$ & $\mathrm{g} / \mathrm{kg}$ & $5-10 \mathrm{~cm}$ & 2003-2010 & Limed & -0.02 & 0.32 & $-0.38-0.33$ \\
\hline $\mathrm{N}_{\text {tot }}$ & $\mathrm{g} / \mathrm{kg}$ & $5-10 \mathrm{~cm}$ & 2010-2015 & Control & 0.24 & 0.28 & $-0.17-0.5$ \\
\hline $\mathrm{N}_{\text {tot }}$ & $\mathrm{g} / \mathrm{kg}$ & $5-10 \mathrm{~cm}$ & 2010-2015 & Limed & 0.09 & 0.23 & $-0.22-0.34$ \\
\hline $\mathrm{N}_{\text {tot }}$ & $\mathrm{g} / \mathrm{kg}$ & $10-30 \mathrm{~cm}$ & 2003-2010 & Control & -0.07 & 0.24 & $-0.31-0.2$ \\
\hline $\mathrm{N}_{\text {tot }}$ & $\mathrm{g} / \mathrm{kg}$ & $10-30 \mathrm{~cm}$ & 2003-2010 & Limed & 0.1 & 0.33 & $-0.23-0.64$ \\
\hline$N_{\text {tot }}$ & $\mathrm{g} / \mathrm{kg}$ & $10-30 \mathrm{~cm}$ & 2010-2015 & Control & 0.23 & 0.2 & $-0.02-0.49$ \\
\hline
\end{tabular}


Table A4. Cont.

\begin{tabular}{cccccccc}
\hline Parameter & Unit & Depth & Period & Treatment & RR Mean & RR SD & RR Range \\
\hline $\mathrm{N}_{\text {tot }}$ & $\mathrm{g} / \mathrm{kg}$ & $10-30 \mathrm{~cm}$ & $2010-2015$ & Limed & 0.02 & 0.26 & $-0.34-0.32$ \\
$\mathrm{~N}_{\text {tot }}$ & $\mathrm{g} / \mathrm{kg}$ & $30-60 \mathrm{~cm}$ & $2003-2010$ & Control & 0.1 & 0.33 & $-0.18-0.61$ \\
$\mathrm{~N}_{\text {tot }}$ & $\mathrm{g} / \mathrm{kg}$ & $30-60 \mathrm{~cm}$ & $2003-2010$ & Limed & 0.04 & 0.15 & $-0.14-0.19$ \\
$\mathrm{~N}_{\text {tot }}$ & $\mathrm{g} / \mathrm{kg}$ & $30-60 \mathrm{~cm}$ & $2010-2015$ & Control & 0.14 & 0.28 & $-0.11-0.58$ \\
$\mathrm{~N}_{\text {tot }}$ & $\mathrm{g} / \mathrm{kg}$ & $30-60 \mathrm{~cm}$ & $2010-2015$ & Limed & -0.01 & 0.15 & $-0.24-0.18$ \\
$\mathrm{pH}-\mathrm{KCl}$ & & O-layer & $2003-2010$ & Control & 0.16 & 0.2 & $-0.01-0.5$ \\
$\mathrm{pH}-\mathrm{KCl}$ & & O-layer & $2003-2010$ & Limed & 1.79 & 0.76 & $0.68-2.78$ \\
$\mathrm{pH}-\mathrm{KCl}$ & & O-layer & $2010-2015$ & Control & -0.03 & 0.21 & $-0.3-0.26$ \\
$\mathrm{pH}-\mathrm{KCl}$ & & O-layer & $2010-2015$ & Limed & -0.32 & 0.78 & $-1.11-0.84$ \\
$\mathrm{pH}-\mathrm{KCl}$ & & $0-5 \mathrm{~cm}$ & $2003-2010$ & Control & 0.11 & 0.14 & $-0.06-0.24$ \\
$\mathrm{pH}-\mathrm{KCl}$ & & $0-5 \mathrm{~cm}$ & $2003-2010$ & Limed & 0.65 & 0.36 & $0.29-1.2$ \\
$\mathrm{pH}-\mathrm{KCl}$ & & $0-5 \mathrm{~cm}$ & $2010-2015$ & Control & -0.04 & 0.15 & $-0.22-0.17$ \\
$\mathrm{pH}-\mathrm{KCl}$ & & $0-5 \mathrm{~cm}$ & $2010-2015$ & Limed & 0.07 & 0.23 & $-0.19-0.27$ \\
$\mathrm{pH}-\mathrm{KCl}$ & & $5-10 \mathrm{~cm}$ & $2003-2010$ & Control & 0.15 & 0.23 & $-0.13-0.48$ \\
$\mathrm{pH}-\mathrm{KCl}$ & & $5-10 \mathrm{~cm}$ & $2003-2010$ & Limed & 0.35 & 0.29 & $0.04-0.67$ \\
$\mathrm{pH}-\mathrm{KCl}$ & & $5-10 \mathrm{~cm}$ & $2010-2015$ & Control & -0.08 & 0.17 & $-0.27-0.16$ \\
$\mathrm{pH}-\mathrm{KCl}$ & & $5-10 \mathrm{~cm}$ & $2010-2015$ & Limed & 0.03 & 0.04 & $-0.03-0.07$ \\
$\mathrm{pH}-\mathrm{KCl}$ & & $10-30 \mathrm{~cm}$ & $2003-2010$ & Control & 0.18 & 0.14 & $-0.02-0.31$ \\
$\mathrm{pH}-\mathrm{KCl}$ & & $10-30 \mathrm{~cm}$ & $2003-2010$ & Limed & 0.14 & 0.07 & $0.07-0.24$ \\
$\mathrm{pH}-\mathrm{KCl}$ & & $10-30 \mathrm{~cm}$ & $2010-2015$ & Control & -0.07 & 0.1 & $-0.17-0.06$ \\
$\mathrm{pH}-\mathrm{KCl}$ & & $10-30 \mathrm{~cm}$ & $2010-2015$ & Limed & 0.01 & 0.06 & $-0.07-0.08$ \\
$\mathrm{pH}-\mathrm{KCl}$ & & $30-60 \mathrm{~cm}$ & $2003-2010$ & Control & 0.04 & 0.15 & $-0.1-0.26$ \\
$\mathrm{pH}-\mathrm{KCl}$ & & $30-60 \mathrm{~cm}$ & $2003-2010$ & Limed & 0.12 & 0.14 & $-0.08-0.27$ \\
$\mathrm{pH}-\mathrm{KCl}$ & & $30-60 \mathrm{~cm}$ & $2010-2015$ & Control & 0.07 & 0.17 & $-0.08-0.35$ \\
$\mathrm{pH}-\mathrm{KCl}$ & & $30-60 \mathrm{~cm}$ & $2010-2015$ & Limed & 0.05 & 0.09 & $-0.08-0.16$ \\
\hline
\end{tabular}

\section{References}

1. Paces, T. Weathering rates of gneiss and depletion of exchangeable cations in soils under environmental acidification. J. Geol. Soc. Lond. 1986, 143, 673-677. [CrossRef]

2. Berger, T.W.; Türtscher, S.; Berger, P.; Lindebner, L. A slight recovery of soils from Acid Rain over the last three decades is not reflected in the macro nutrition of beech (Fagus sylvatica) at 97 forest stands of the Vienna Woods. Environ. Pollut. 2016, 216, 624-635. [CrossRef] [PubMed]

3. Majdi, H.; Viebke, C.-G. Effects of fertilization with dolomite lime+ PK or wood ash on root distribution and morphology in a Norway spruce stand in Southwest Sweden. For. Sci. 2004, 50, 802-809. [CrossRef]

4. Cudlin, P.; Kieliszewska-Rokicka, B.; Rudawska, M.; Grebenc, T.; Alberton, O.; Lehto, T.; Bakker, M.R.; Børja, I.; Konôpka, B.; Leski, T.; et al. Fine roots and ectomycorrhizas as indicators of environmental change. Plant Biosyst. 2007, 141, 406-425. [CrossRef]

5. Wellbrock, N.; Eickenscheidt, N.; Grüneberg, E.; Bögelein, R. Environmental settings and their changes in the last decades. In Status and Dynamics of Forests in Germany: Results of the National Forest Monitoring; Wellbrock, N., Bolte, A., Eds.; Springer Nature: Cham, Switzerland, 2019; Volume 237, pp. 29-54. [CrossRef]

6. Homan, C.; Beier, C.; McCay, T.; Lawrence, G. Application of lime $\left(\mathrm{CaCO}_{3}\right)$ to promote forest recovery from severe acidification increases potential for earthworm invasion. For. Ecol. Manag. 2016, 368, 39-44. [CrossRef]

7. Rizvi, S.H.; Gauquelin, T.; Gers, C.; Guérold, F.; Pagnout, C.; Baldy, V. Calcium-magnesium liming of acidified forested catchments: Effects on humus morphology and functioning. Appl. Soil Ecol. 2012, 62, 81-87. [CrossRef]

8. Ulrich, B. Soil acidity and its relations to acid deposition. In Effects of Accumulation of Air Pollutants in Forest Ecosystems; Ulrich, B., Pankrath, J., Eds.; Springer: Dordrecht, The Netherlands, 1983; pp. 127-146. [CrossRef]

9. Heisner, U.; Wilpert, K.; Hildebrand, E.E. Vergleich aktueller Messungen zum Aziditätsstatus südwestdeutscher Waldböden mit historischen Messungen von 1927. Allg. Forst Und Jagdztg. 2003, $174,41-44$. 
10. Drápelová, I.; Kulhavý, J. Comparison of soil and seepage water properties in the limed and not-limed spruce forest stands in the Beskydy Mts. Beskydy 2012, 5, 55-64. [CrossRef]

11. Pavlu, L.; Drabek, O.; Stejskalova, S.; Tejnecky, V.; Hradilova, M.; Nikodem, A.; Boruvka, L. Distribution of aluminium fractions in acid forest soils: Influence of vegetation changes. iForest 2018, 11, 721-727. [CrossRef]

12. Meesenburg, H.; Riek, W.; Ahrends, B.; Eickenscheidt, N.; Grüneberg, E.; Evers, J.; Fortmann, H.; König, N.; Lauer, A.; Meiwes, K.J.; et al. Soil acidification in German forest soils. In Status and Dynamics of Forests in Germany: Results of the National Forest Monitoring; Wellbrock, N., Bolte, A., Eds.; Springer Nature: Cham, Switzerland, 2019; Volume 237, pp. 93-121. [CrossRef]

13. Court, M.; van der Heijden, G.; Didier, S.; Nys, C.; Richter, C.; Pousse, N.; Saint-André, L.; Legout, A. Long-term effects of forest liming on mineral soil, organic layer and foliage chemistry: Insights from multiple beech experimental sites in Northern France. For. Ecol. Manag. 2018, 409, 872-889. [CrossRef]

14. UNECE. Convention on Long-range Transboundary Air Pollution (CLRTAP); United Nations Economic Commission for Europe: Geneva, Switzerland, 1979.

15. Jonard, M.; Fürst, A.; Verstraeten, A.; Thimonier, A.; Timmermann, V.; Potočič, N.; Waldner, P.; Benham, S.; Hansen, K.; Merilä, P.; et al. Tree mineral nutrition is deteriorating in Europe. Glob. Chang. Biol. 2015, 21, 418-430. [CrossRef]

16. Li, Y.; Cui, S.; Chang, S.X.; Zhang, Q. Liming effects on soil pH and crop yield depend on lime material type, application method and rate, and crop species: A global meta-analysis. J. Soils Sediments 2018, 19, 1393-1406. [CrossRef]

17. Reid, C.; Watmough, S.A. Evaluating the effects of liming and wood-ash treatment on forest ecosystems through systematic meta-analysis. Can. J. For. Res. 2014, 44, 867-885. [CrossRef]

18. Saarsalmi, A.; Tamminen, P.; Kukkola, M.; Levula, T. Effects of liming on chemical properties of soil, needle nutrients and growth of Scots pine transplants. For. Ecol. Manag. 2011, 278-285. [CrossRef]

19. Šrámek, V.; Fadrhonsová, V.; Vortelová, L.; Lomský, B. Development of chemical soil properties in the western Ore Mts. (Czech Republic) 10 years after liming. J. For. Sci. 2012, 58, 57-66. [CrossRef]

20. Ouimet, R.; Moore, J.-D. Effects of fertilization and liming on tree growth, vitality and nutrient status in boreal balsam fir stands. For. Ecol. Manag. 2015, 345, 39-49. [CrossRef]

21. Fleck, S.; Eickenscheidt, N.; Ahrends, B.; Evers, J.; Grüneberg, E.; Ziche, D.; Höhle, J.; Schmitz, A.; Weis, W.; Schmidt-Walter, P.; et al. Nitrogen status and dynamics in German forest soils. In Status and Dynamics of Forests in Germany: Results of the National Forest Monitoring; Wellbrock, N., Bolte, A., Eds.; Springer Nature: Cham, Switzerland, 2019; Volume 237, pp. 123-166. [CrossRef]

22. Littek, T. Zum Stand der Praxis-Düngeversuche in Baden-Württemberg. In Versuche zur Minderung der Walderkrankung; Littek, T., Adam, K., Eds.; Mitteilungen der Forstlichen Versuchs- und Forschungsanstalt Baden-Württemberg: Freiburg, Germany, 1985; Volume 119, pp. 1-25.

23. Wilpert, K.; Hildebrand, E.E.; Huth, T. Ergebnisse des Praxis-Großdüngeversuches: Abschlußbericht über die Anfangsaufnahmen (1985/86) und die Endaufnahmen (1989/90); Mitteilungen der Forstlichen Versuchs- und Forschungsanstalt Baden-Württemberg: Freiburg, Germany, 1993; Volume 171.

24. FAO. Guidelines for Soil Description, 4th ed.; Food and Agriculture Organization of the United Nations: Rome, Italy, 2006; pp. 25-29.

25. Ad-hoc-Arbeitsgruppe Boden. Bodenkundliche Kartieranleitung, 5th ed.; Bundesanstalt für Geowissenschaften und Rohstoffe in Zusammenarbeit mit den Staatlichen Geologischen Diensten: Hannover, Germany, 2005; pp. 303-310.

26. GAFA (Ed.) Handbuch Forstliche Analytik (HFA): Grundwerk des Gutachterausschuss Forstliche Analytik (GAFA); Federal Ministry of Food, Agriculture and Consumer Protection, Northwest German Forest Research Institute: Bonn, Germany, 2005.

27. GAFA (Ed.) Handbuch Forstliche Analytik (HFA): Grundwerk und 1.-4. Ergänzung des Gutachterausschuss Forstliche Analytik (GAFA); Federal Ministry of Food, Agriculture and Consumer Protection, Northwest German Forest Research Institute: Bonn, Germany, 2008.

28. GAFA (Ed.) Handbuch Forstliche Analytik (HFA): Grundwerk und 1.-5. Ergänzung des Gutachterausschuss Forstliche Analytik (GAFA); Federal Ministry of Food, Agriculture and Consumer Protection, Northwest German Forest Research Institute: Bonn, Germany, 2014.

29. Hedges, L.V.; Gurevitch, J.; Curtis, P.S. The meta-analysis of response ratios in experimental ecology. Ecology 1999, 80, 1150-1156. [CrossRef] 
30. Schöpp, W.; Posch, M.; Mylona, S.; Johannsson, M. Long-term development of acid deposition (1880-2030) in sensitive freschwater regions in Europe. Hydrol. Earth Syst. Sci. 2003, 7, 436-446. [CrossRef]

31. Kretzschmar, R. Chemische Eigenschaften und Prozesse. In Scheffer/Schachtschabel Lehrbuch der Bodenkunde, 17th ed.; Amelung, W., Blume, H.-P., Fleige, H., Horn, R., Kandeler, E., Kögel-Knabner, I., Kretzschmar, R., Stahr, K., Wilke, B.-M., Eds.; Springer Spektrum: Berlin, Germany, 2018; pp. 151-211. [CrossRef]

32. Pabian, S.E.; Rummel, S.M.; Sharpe, W.E.; Brittingham, M.C. Terrestrial liming as a restoration technique for acidified forest ecosystems. Int. J. For. Res. 2012, 2012, 1-10. [CrossRef]

33. Huber, C.; Baier, R.; Göttlein, A.; Weis, W. Changes in soil, seepage water and needle chemistry between 1984 and 2004 after liming an N-saturated Norway spruce stand at the Höglwald, Germany. For. Ecol. Manag. 2006, 233, 11-20. [CrossRef]

34. Guckland, A.; Ahrends, B.; Paar, U.; Dammann, I.; Evers, J.; Meiwes, K.J.; Schönfelder, E.; Ullrich, T.; Mindrup, M.; König, N.; et al. Predicting depth translocation of base cations after forest liming: Results from long-term experiments. Eur. J. For. Res. 2012, 131, 1869-1887. [CrossRef]

35. Löfgren, S.; Cory, N.; Zetterberg, T.; Larsson, P.E.; Kronnäs, V. The long-term effects of catchment liming and reduced sulphur deposition on forest soils and runoff chemistry in southwest Sweden. For. Ecol. Manag. 2009, 258, 567-578. [CrossRef]

36. Cools, N.; Vesterdal, L.; de Vos, B.; Vanguelova, E.; Hansen, K. Tree species is the major factor explaining C:N ratios in European forest soils. For. Ecol. Manag. 2014, 311, 3-16. [CrossRef]

(C) 2020 by the authors. Licensee MDPI, Basel, Switzerland. This article is an open access article distributed under the terms and conditions of the Creative Commons Attribution (CC BY) license (http://creativecommons.org/licenses/by/4.0/). 